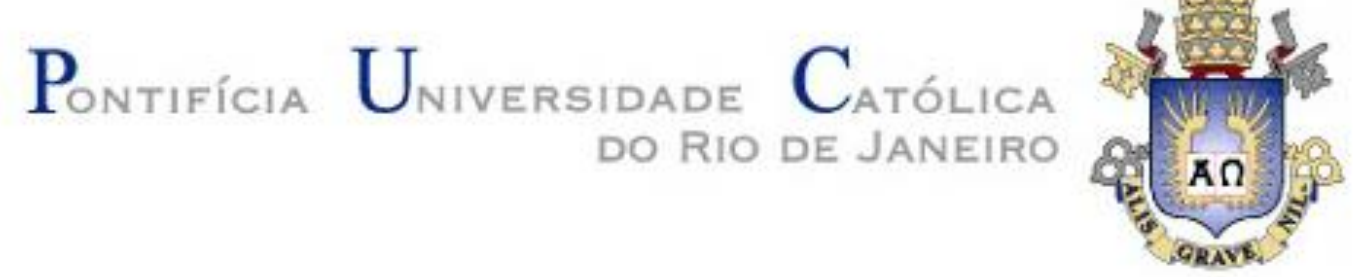

Regina Paula Baldez Trinta

\title{
Caracterização do clínquer e comportamento físico-mecânico do cimento
}

Dissertação de Mestrado

Dissertação apresentada como requisito parcial para obtenção do grau de Mestre pelo Programa de PósGraduação em Engenharia de Materiais e de Processos Químicos e Metalúrgicos da PUC- Rio.

Orientador: Prof. Francisco José Moura Coorientador: Prof. Roberto Ribeiro de Avillez 
Regina Paula Baldez Trinta

\section{Caracterização do clínquer e comportamento físico-mecânico do cimento}

Dissertação apresentada como requisito parcial para obtenção do grau de Mestre pelo Programa de Pósgraduação em Engenharia de Materiais e de Processos Químicos e Metalúrgicos da PUC-Rio. Aprovada pela Comissão Examinadora abaixo.

Prof. Francisco José Moura

Orientador

Departamento de Engenharia Química e de Materiais - PUC-Rio

Prof. Roberto Ribeiro de Avillez

Coorientador

Departamento de Engenharia Química e de Materiais - PUC-Rio

Prof. Rodrigo Fernandes Magalhães de Souza

Departamento de Engenharia Química e de Materiais - PUC-Rio

Prof. Alexandre Vargas Grillo Instituto Federal do Rio de Janeiro-IFRJ 
Todos os direitos reservados. É proibida a reprodução total ou parcial trabalho sem autorização da universidade, da autora e do orientador.

\section{Regina Paula Baldez Trinta}

Formada em Engenharia Química e Produção Química pela Pontifícia Universidade Católica do Rio de Janeiro em 2002. Cursou MBA em Gestão Empresarial pela FGV em 2008. Possui experiência nas áreas de Processos Químicos no setor de cimento, Meio Ambiente e em Segurança do Trabalho.

Ficha Catalográfica

Trinta, Regina Paula Baldez

Caracterização do clínquer e comportamento físico-mecânico do cimento/ Regina Paula Baldez Trinta; orientador: Francisco José Moura; co-orientador: Roberto Ribeiro de Avillez. - 2019.

102 f. il. color. ; $30 \mathrm{~cm}$

Dissertação (mestrado)-Pontifícia Universidade Católica do Rio de Janeiro, Departamento de Engenharia Química e de Materiais, 2019.

Inclui bibliografia

1.Engenharia Química e de Materiais - Teses. 2. Coprocessamento. 3. Reatividade do Clínquer 4. Análise de Componentes Principais. 5. Comportamento físico-mecânico do cimento. I. Moura, Francisco José. II. Avillez, Roberto Ribeiro de. III. Pontifícia Universidade Católica do Rio de Janeiro. Departamento de Engenharia Química e de Materiais. IV. Título. 


\section{Agradecimentos}

À Deus, por me dar tranquilidade juntamente com minha família em superar um momento difícil de saúde (câncer de mama).

À minha mãe, Rosires e irmã, Ana Maria, por sempre me apoiarem a todo instante, incentivando na luta pelo alcance dos meus objetivos.

Ao meu orientador Prof. Francisco José Moura pela orientação, apoio, incentivo e solidariedade, as quais foram importantes para elaboração do trabalho.

Ao meu co-orientador Prof. Roberto Avillez, que me ajudou na elaboração do tema do trabalho, na análise dos resultados de Difração de Raios-X e no desenvolvimento da metodologia estatística PCA.

Ao Alício Cavalcanti, Lorena Mathias e equipe do Laboratório da Votorantim Cantagalo pelo interesse e esforço na coleta de amostras e no apoio a execução dos ensaios químicos e físicos.

Ao Prof. Eduardo Brocchi e aos demais professores do DEQM os quais tive oportunidade de interagir ao longo do período do curso de mestrado.

Aos funcionários do DEQM, em especial, Carmem Façanha (secretaria), Henrique (casa XXI) e Asafe (metalografia), sempre solícitos.

À Sonia Letichevsky pelo apoio à execução dos ensaios de Difração de Raios $\mathrm{X}$.

Ao $\mathrm{CNPq}$ e PUC-Rio, pelo apoio financeiro, sem o qual não teria sido possível a realização deste trabalho.

O presente trabalho foi realizado com apoio da Coordenação de Aperfeiçoamento de Pessoal de Nível Superior - Brasil (CAPES)-Código de Financiamento 001. 


\section{Resumo}

Trinta, Regina Paula Baldez; Moura, Francisco José; Avillez, Roberto de Caracterização do clínquer e comportamento físico-mecânico do cimento. Rio de Janeiro, 2019.102p. Dissertação do mestrado -Departamento de Engenharia Química e de Materiais, Pontificia Universidade Católica do Rio de Janeiro.

Atualmente, a indústria cimenteira tem usado o coprocessamento no intuito de atender a aspectos econômicos e de sustentabilidade por meio da utilização de resíduos industriais como matérias-primas e/ou combustíveis não convencionais. Isto pode gerar, através da introdução de maior variabilidade de elementos menores, consequências nas reações de clinquerização com geração de modificações morfológicas dos cristais e nas propriedades que influenciam estas reações (tensão superficial, viscosidade). Em função da maior utilização do coprocessamento, as análises mineralógica e microestrutural se tornaram ainda mais significativas para apoio a formação do diagnóstico do processo incluindo o grau de reatividade do clínquer e por sua vez, previsões do desempenho do cimento. No entanto, o número de variáveis de controle do forno de clinquer é tão elevado que se propôs o emprego da metodologia estatística chamada Análise de Componentes Principais (PCAPrincipal Analysis Components em inglês) para escolher as de maior representatividade. Os resultados da caracterização mineralógica do clínquer coprocessado com o resíduo CSS50 utilizando o Método de Rietveld/Difração de Raios-X dos quatro principais constituintes do clínquer foram próximos aos valores teóricos (potenciais de Bogue). A fase predominante do $\mathrm{C}_{3} \mathrm{~S}$ foi monoclínica, típica de clínqueres industriais, e quanto ao $\mathrm{C}_{3} \mathrm{~A}$, a fase predominante foi cúbica. $\mathrm{O}$ diagnóstico apresentado pela caracterização microestrutural apresentou clínquer com alta reatividade. Quanto ao cimento coprocessado com o resíduo CSS50, foram realizados os ensaios físico-mecânicos: tempo de pega e resistência a compressão, conforme ABNT NBR 16607 e NBR 7215. Os ensaios de tempo de pega e resistência à compressão do cimento atenderam plenamente a norma ABNT NBR 16697.

\section{Palavras-chave}

Coprocessamento; reatividade do clínquer; análise de componentes principais; comportamento físico-mecânico; cimento. 


\section{Abstract}

Trinta, Regina Paula Baldez; Moura, Francisco José (Advisor); Avillez, Roberto Ribeiro de (Coadvisor). Characterization of clinker and physicalmechanical behavior of cement. Rio de Janeiro, 2019. 102 p. Dissertação de Mestrado - Departamento de Engenharia Química e de Materiais, Pontifícia Universidade Católica do Rio de Janeiro.

Currently, the cement industry uses the coprocessing of industries residues as raw materials or alternative fuel for attending economics and the sustainability aspects. This procedure can introduce a variety of minor elements that can affect the clinkerization reactions by producing morphological changes of the clinker crystals and changing the surface tension and viscosity. Thus, mineralogic and microstrutural characterizations are necessary to understand the clinker reactivity and its effect on the Portland cement properties. Nonetheless, the number of clinquer kiln control variables is enormous, and it is proposed to use the Principal Component Analysis (PCA) to choose the most important ones. The X-ray diffraction characterization of the clinker showed that the four major constituents are consistent with the theorical values (Bogue potentials). The $\mathrm{C}_{3} \mathrm{~S}$ phase was monoclinic, which is usual for industrial clinkers, and the $\mathrm{C}_{3} \mathrm{~A}$ phase was usually cubic. These results suggest that the formation of a high reactivity clinker. The physico-mechanical characterizations "setting time" and "compressive strength" of the Portland cement were conducted according to NBR 16607 and NBR 7215 ABNT norms. The Portland Cement results agreed with the NBR 16697 ABNT norm.

\section{Keywords}

Coprocessing; clinker reactivity; principal components analysis; physicalmechanical behavior; cement. 


\section{Sumário}

1 Introdução 12

1.1. Objetivo Geral 17

$\begin{array}{ll}\text { 1.2. Objetivos Específicos } & 17\end{array}$

2 Revisão Bibliográfica 19

2.1. Processo de Fabricação de Cimento 19

2.1. 1. Aspectos Gerais 19

2.1.2 . Tipos de Sistema de Alimentação do forno rotativo 19

2.1.3. Matéria-Prima - Extração, dosagem e preparação 23

2.1.4. Combustíveis 27

2.1.5. Processo de clinquerização 29

2.1.6. Moagem de Cimento: tipos de cimentos e adições 34

$\begin{array}{ll}\text { 2.2. Coprocessamento } & 37\end{array}$

2.2.1. Aspectos Gerais 37

2.2.2. Panorama do Coprocessamento no Brasil e no Mundo 37

2.2.3. Vantagens do co-processamento 40

2.2.4. Coprocessamento do resíduo CSS50 41

2.3. Mineralogia do clínquer 41

2.3.1. Alita ou silicato tricálcico $\left(\mathrm{C}_{3} \mathrm{~S}\right)$

2.3.2. Belita ou Silicato bicálcico $\left(\mathrm{C}_{2} \mathrm{~S}\right)$

2.3.3. Aluminato tricálcico $\left(\mathrm{C}_{3} \mathrm{~A}\right) \quad 49$

2.3.4. Ferroaluminato tetracálcico $\left(\mathrm{C}_{4} \mathrm{AF}\right)$

2.3.5. Cal livre, periclásio e os sulfatos alcalinos. 52

2.4. Influência dos elementos menores no clínquer 54

2.5. Fundamentos de PCA 59

2.5.1. Definição 59

2.5.2. Sistemática de processamento de dados 61

2.5.3. Interpretação dos resultados do PCA 64

3 Metodologia Experimental 68 
$\begin{array}{ll}\text { 3.1. Amostragem } & 68\end{array}$

3.2. Ensaios de Caracterização Tecnológica 69

3.2.1. Espectrometria de Fluorescência de Raios-X 69

3.2.2. Difração de Raios-X 69

3.2.3. Microscopia Ótica 72

3.3. Caracterização do clínquer utilizando a abordagem PCA 75

3.4. Ensaios de Desempenho Físico-Mecânico 77

4 Resultados e Discussão 78

4.1. Caracterização tecnológica da farinha, pó de retorno e clínquer 78

$\begin{array}{ll}\text { 4.1.1. Composição química } & 78\end{array}$

4.1.2. Composição mineralógica 79

4.1.3. Análise Microestrutural 82

4.2. Caracterização do clínquer pelo PCA 87

4.3. Ensaios de desempenho físico-mecânico 93

4.3.1. Tempo de Pega 93

4.3.2. Resistência a compressão 93

5 Conclusões $\quad 95$

6 Recomendações para Trabalhos Futuros 97

7 Referências bibliográficas $\quad 98$ 


\section{Lista de Figuras}

Figura 1-Empresas produtoras de cimento no mundo......................................... 13

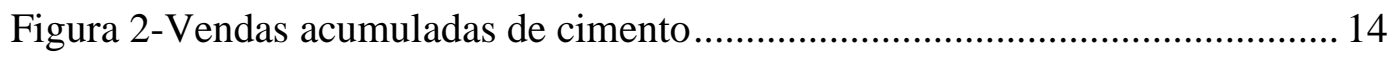

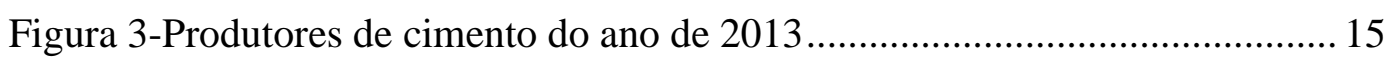

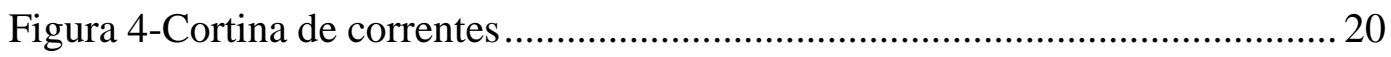

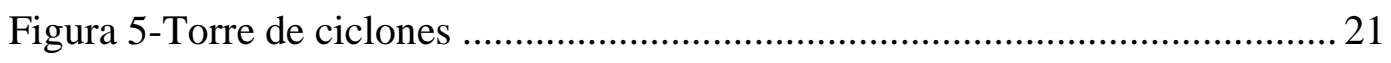

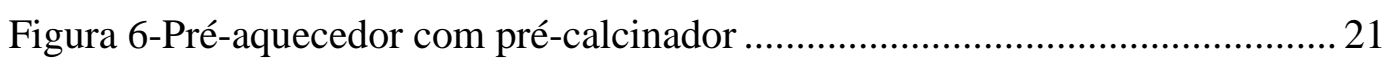

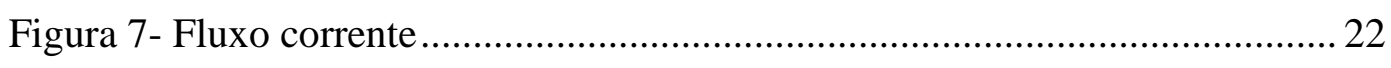

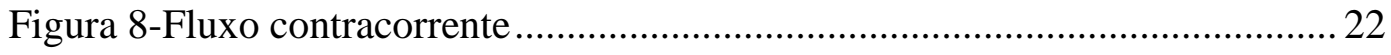

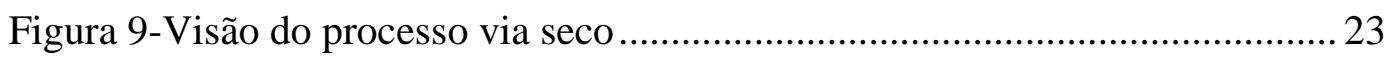

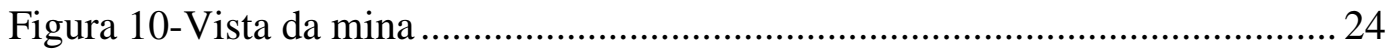

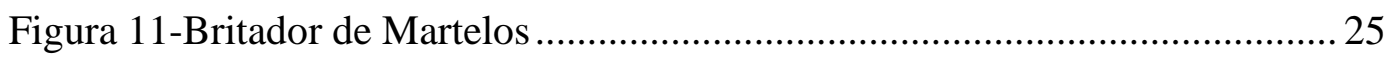

Figura 12- Matriz energética do setor de cimento ............................................. 28

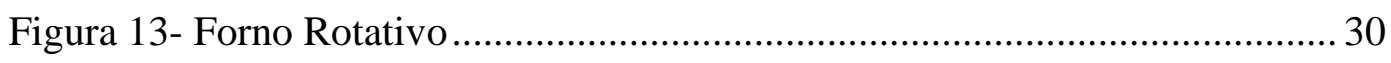

Figura 14-Ponteira do maçarico com as saídas de ar ......................................... 30

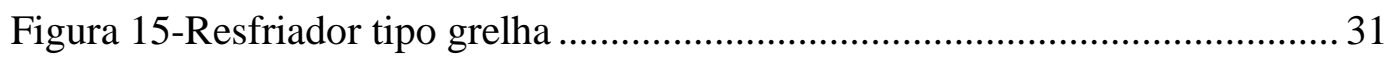

Figura 16-Resfriador tipo satélite ................................................................ 31

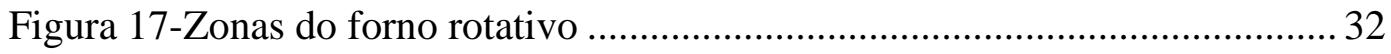

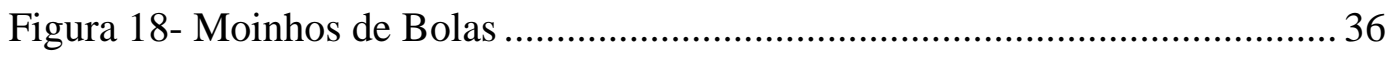

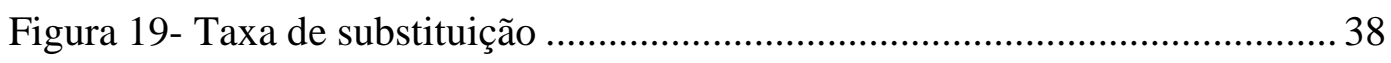

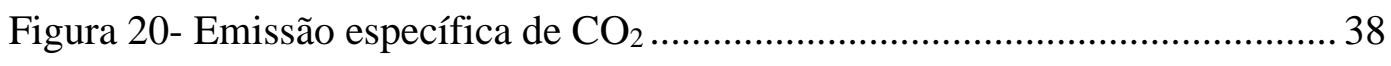

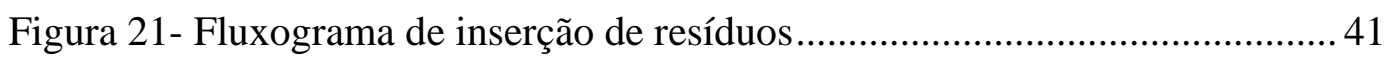

Figura 22-Evolução mineralógica do clínquer ..................................................... 42

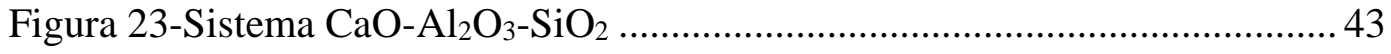

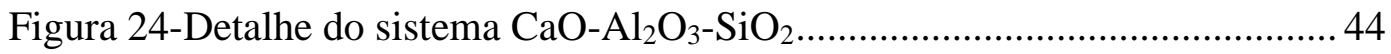

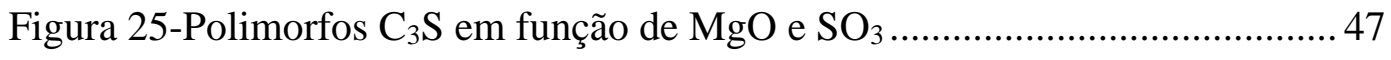

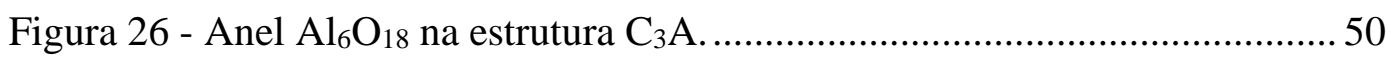

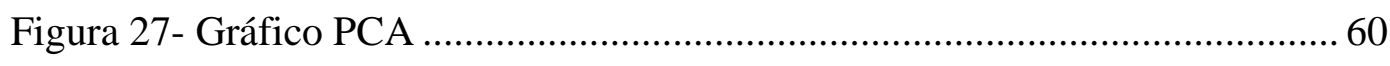

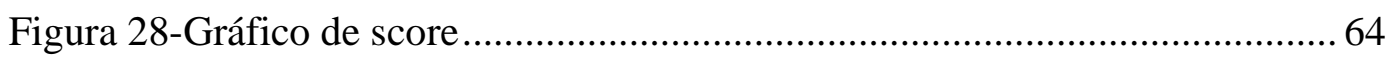

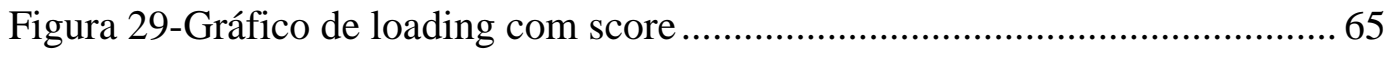

Figura 30-Biplot de qualidades artísticas de pintores .........................................6 67 


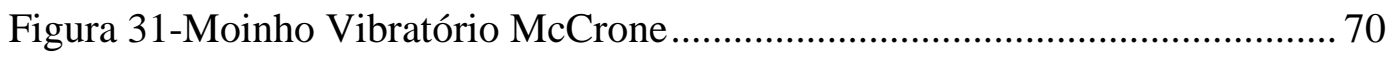

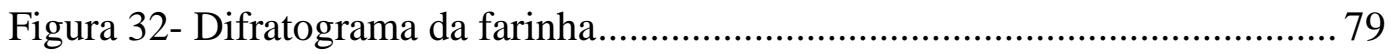

Figura 33- Difratograma do pó de retorno ….................................................... 79

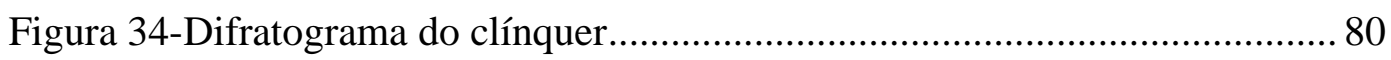

Figura 35-Pouca frequência de zonas regulares de $\mathrm{C}_{2} \mathrm{~S}$................................ 82

Figura 36-Cristais Equidimensionais de alita (A) e fase intersticial (F) .............. 83

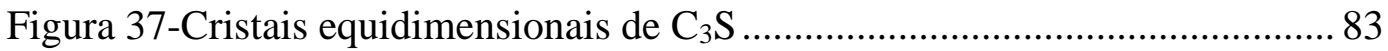

Figura 38- Cristais de $\mathrm{C}_{3} \mathrm{~S}$ subdiomórficos e $\mathrm{C}_{2} \mathrm{~S}$ em início de digitação............. 84

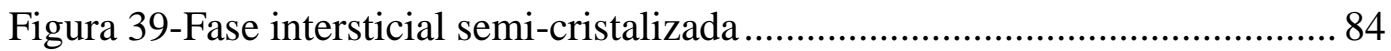

Figura 40-Cristais de C3S sub-retilíneas com leve início de digitação do $\mathrm{C}_{2} \mathrm{~S} \ldots . .85$

Figura 41-Fase semi-cristalizada sem distinção da fase intersticial ...................... 86

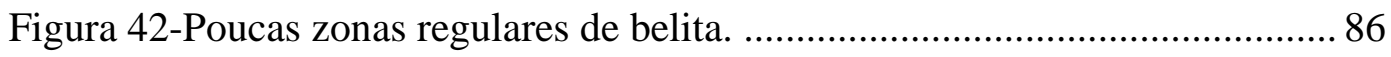

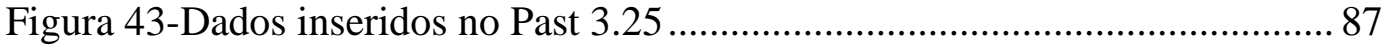

Figura 44-Variâncias dos 8 primeiros componentes principais ............................ 88

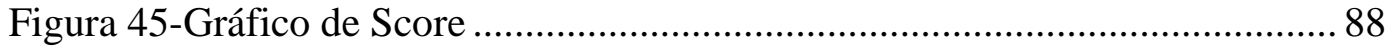

Figura 46-Gráfico em barra de loading do PC1 _.................................................. 90

Figura 47-"Screeplot" com círculo de linha preta que indica o ponto de corte..... 92 


\section{Lista de tabelas}

Tabela 1 - Teores de $\mathrm{CaO}$ no calcário argila 25

Tabela 2 - Composição química de argilas 26

Tabela 3 - Módulos químicos 27

Tabela 4 - Propriedades dos combustíveis 29

Tabela 5 - Faixas de temperatura das zonas do forno 32

Tabela 6 - Residuos industriais utilizados no coprocessamento 39

Tabela 7 - Composição do clínquer $\quad 42$

Tabela 8 - Polimorfismo da alita 45

Tabela 9 - Polimorfismo da belita 48

Tabela 10-Concentração média de elementos menores e traços encontrados no clínquer

Tabela 11-Concentração média de elementos menores em calcários e argilas 56

Tabela 12-Concentração média de elementos menores e traços em $\begin{array}{ll}\text { combustíveis } & 57\end{array}$

Tabela 13 - Condições operacionais da difração de raios X 70

Tabela 14 - Resposta ao ataque dos reagentes químicos 74

Tabela 15 - Forma e estrutura dos cristais $\quad 74$

Tabela 16 - Composição Química dos insumos 78

Tabela 17 - Comparação de valores de potenciais de Bogue com Difração de $\begin{array}{ll}\text { Raios } & 80\end{array}$

Tabela 18 - Indicadores do refinamento $\quad 81$

Tabela 19 - Valores de tempo de pega 93

Tabela 20 - Valores de resistência a compressão 94 


\section{Introdução}

Cimentos podem ser definidos como substâncias aglomerantes capazes de unir fragmentos de massa de material sólido para um compacto inteiro quando entra em contato com a água. Tal definição engloba um grande número de substâncias muito diferentes que não têm nada em comum, a não ser ter essa característica aglomerante que sejam capazes de unir pedras, tijolos na construção civil e trabalhos de engenharia (Lea, 1998).

A história remonta há 4500 anos (ABCP, 2009) com as obras de pirâmides do antigo Egito por meio da utilização do gesso calcinado e as gregas e romanas, o Panteão e o Coliseu, com base de cinzas vulcânicas que também endureciam quando misturadas à água. Apesar disso, apenas em 1824, houve o patenteamento pelo construtor inglês Joseph Aspdin do processo de fabricação do cimento Portland. Ele foi considerado o precursor do cimento moderno. O nome cimento "Portland" faz referência às mesmas propriedades de durabilidade e solidez das rochas da ilha britânica de Portland.

Certamente, o primeiro cimento elaborado por Aspdin é diferente em termos de mineralogia e atividade hidráulica. Entretanto, foi fundamental para o desenvolvimento e avanço tecnológico do cimento (Lea, 1998).

O cimento Portland é um pó fino com propriedades aglomerantes que endurece sob a ação da água. É composto de clínquer e adições. O clínquer é o principal componente e está presente em todos os tipos de cimento Portland. As adições podem variar de um tipo de cimento para outro e tem papel decisivo na definição dos diferentes tipos de cimento.

O clínquer consiste basicamente na mistura de calcário e argila que passa pelo forno a $1450^{\circ} \mathrm{C}$ e é imediatamente resfriado. Este produto do forno tem aparência granular, cinza escuro e tem como característica ser um forte ligante hidráulico quando moído. Na presença de água, este se torna pastoso, primeiramente, em seguida, acontece o endurecimento, adquirindo resistência e durabilidade. 
A indústria do cimento exerce forte influência no desenvolvimento da infraestrutura econômica e social de um país. Este setor está diretamente ligado à construção civil, portanto norteia a demanda por cimento. Portanto, o incremento da construção civil por meio de obras de construção pesada (barragens, rodovias, obras de saneamento, etc.), de edificações (habitação, prédios comerciais e industriais), de construções específicas (terraplanagem, instalações, etc.) e o setor informal (pequenas obras e reformas) influenciam no consumo do cimento no mercado interno. E por sua vez, fornece apoio ao crescimento de um país com a evolução das obras de infra-estrutura e a redução do déficit habitacional. Isto elucida que a indústria do cimento é um bom indicador do crescimento e progresso de um país.

Atualmente, o panorama mundial se mostra bastante desafiador devido à diferença de crescimento econômico entre os países do mercado emergente e as incertezas políticas globais que poderão desestabilizar os mercados maduros e cativos de forma a influenciar de forma negativa no seu crescimento. Neste cenário, os países que se destacam como grandes produtores do cimento mundial são China, Índia e Estados Unidos após a sua recuperação econômica. Os três países juntos respondem por 66 por cento de todo o cimento produzido no mundo (Mineral Commodity Summaries, 2017).

A Figura 1 demonstra a produção mundial de cimento (em milhões) por empresa dos anos 2016 e 2017. É possível observar que a LafargeHolcim é líder mundial com produção entre 100 e 120.000 .000 toneladas (Global Cement, 2017).

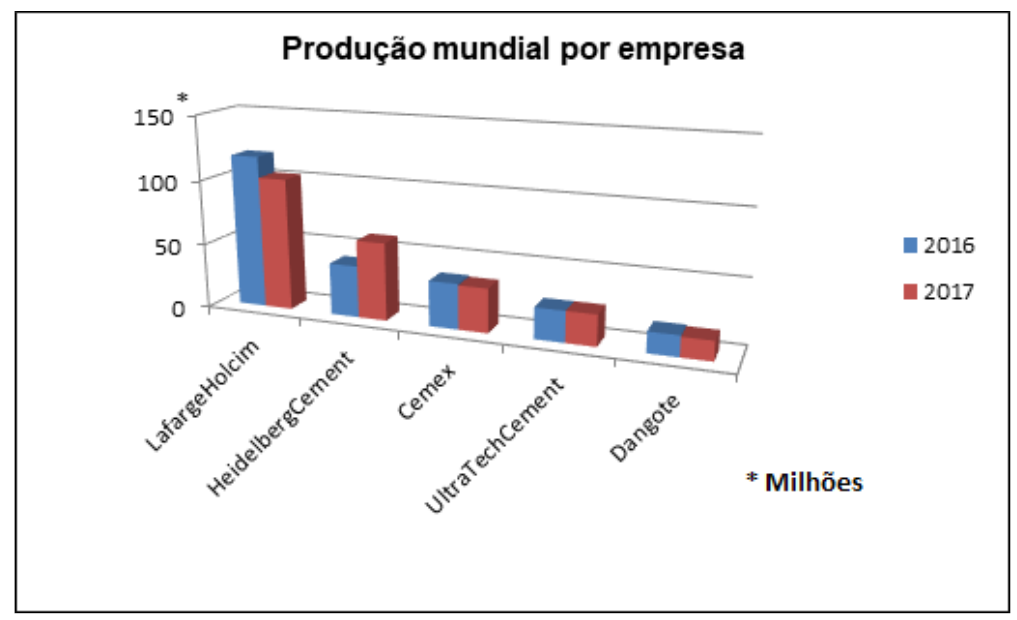

Figura 1-Empresas produtoras de cimento no mundo Fonte: Elaborado a partir de dados da Global Cement (2017) 
No panorama nacional, a partir de 2014, iniciou-se uma crise na construção civil com aumento de juros, restrição ao crédito, escândalos de corrupção envolvendo grandes empreiteiras. A rentabilidade do setor reduziu de 11,2\% em 2013 para 2,3\% em 2014. Isto refletiu diretamente no setor do cimento. Em 2015, registrou-se uma queda de 9,5\% nas vendas de cimento em relação ao ano anterior. No ano de 2016, houve uma queda de $11,7 \%$ em relação a 2015 . E finalmente, no período de janeiro a outubro de 2017, houve uma queda de 6,7\% nas vendas de cimento em relação ao mesmo período do ano anterior. Isto indica uma redução da queda que pode significar o início de uma reação. (Almeida, 2015). A Figura 2 demostra as vendas de cimento acumuladas em 12 meses

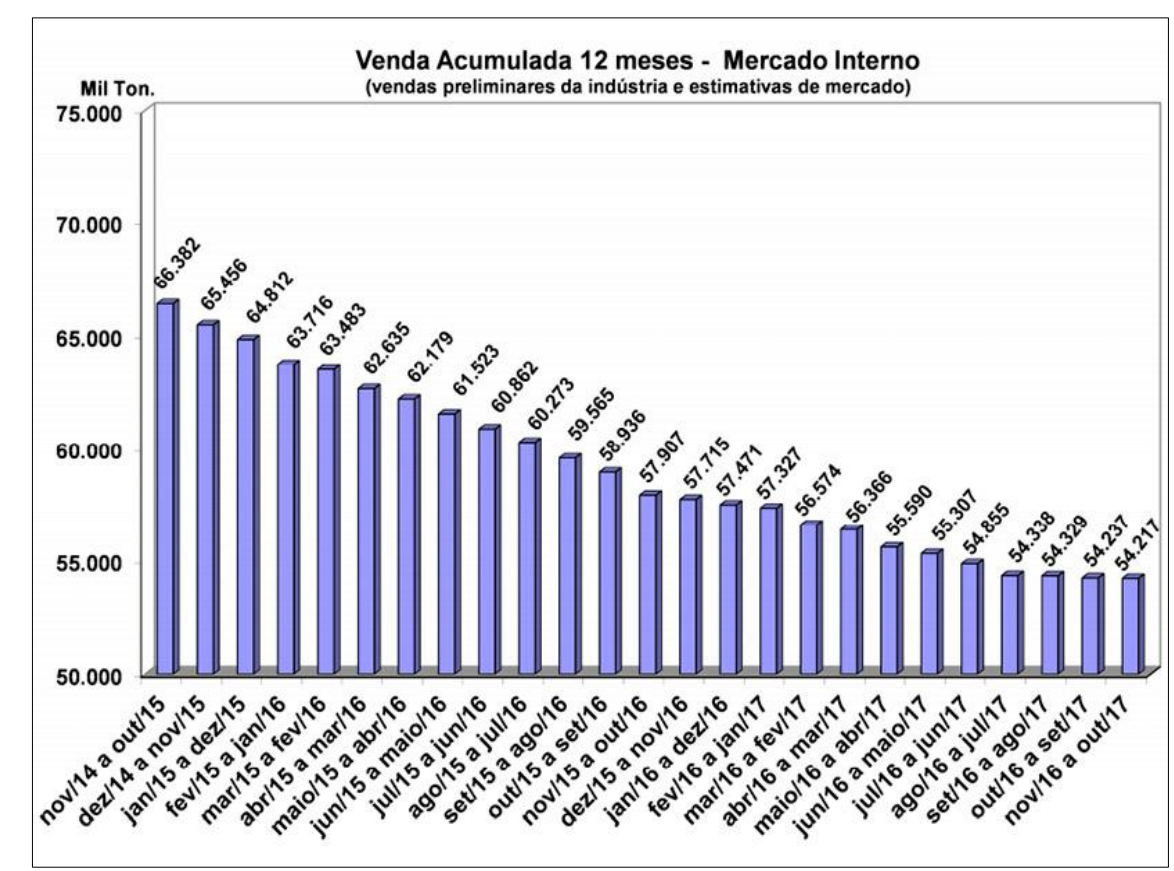

Figura 2-Vendas acumuladas de cimento

Fonte:SNIC,2017

Em 2013, o setor de cimento tinha 15 grupos de produtores nacionais e estrangeiros, com 81 fábricas distribuídas por todas as regiões brasileiras e com uma capacidade de 78 milhões de toneladas por ano (SNIC, 2017). A Figura 3 demostra as produções dos principais grupos produtores de cimento do Brasil no ano de 2013. 


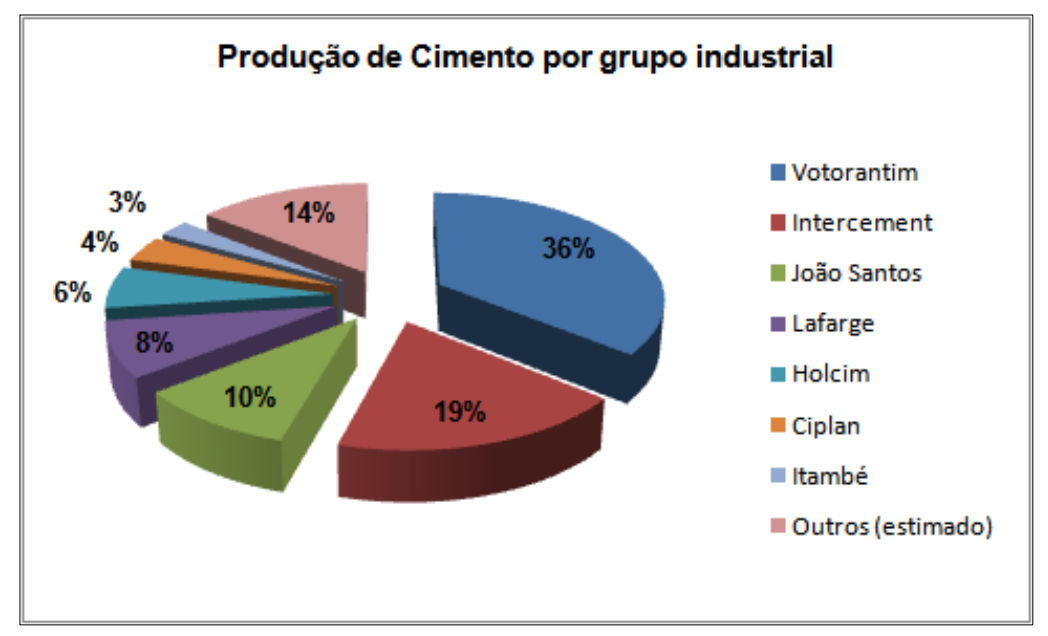

Figura 3-Produtores de cimento do ano de 2013

Fonte: Elaborada pela própria autora a partir dos dados de SNIC (2017)

No cenário nacional atual, o setor de cimento possui 100 fábricas produtoras de cimento controladas por 24 grupos industriais, a capacidade é de 100 milhões de toneladas por ano de cimento e a produção é de 57 milhões de toneladas por ano (SNIC, 2017).

No intuito de atender a crescente demanda social na busca de maior competitividade no mercado, as empresas buscam práticas para o desenvolvimento sustentável da sociedade. Estas práticas são denominadas de sustentabilidade empresarial.

A sustentabilidade empresarial é um direcionador de negócios com ações para desenvolvimento social e ambiental das comunidades no seu entorno. Esta está baseada em preceitos para sua atuação nas dimensões econômica, social e ambiental.

Desde o início dos anos 2000, a indústria de cimento global apóia um dos maiores programas de sustentabilidade já realizados por um único setor industrial. Esta iniciativa, conhecida como Cement Sustainability Inciative (CSI) é um esforço de mais de 20 grandes produtoras de cimento no mundo em prol da sustentabilidade. Nos 10 anos de história, há um esforço em focar no gerenciamento e minimização dos impactos de produção e uso do cimento tais como:

- Mudança climática

- Uso do combustível

- Saúde e segurança dos funcionários

- Emissões no ar 
Dentre outras ações formalizadas pela CSI para o alcance da sustentabilidade para os próximos 20 anos, pode-se citar: produtividade de recursos, gestão ecológica, redução das emissões, bem-estar dos funcionários e da comunidade e geração de valor para o acionista.

O coprocessamento é justamente a técnica que atende ao requisito de redução das emissões. É uma atividade amplamente utilizada na Europa, Estados Unidos, Canadá e no Japão desde a década de 70 e no Brasil, tem crescido desde a década de 90. Este consiste na substituição de parte das matérias-primas convencionais, ou dos combustíveis fósseis não renováveis, sem comprometimento do controle de qualidade do cimento. É regulamentada pelo Conselho Nacional de Meio Ambiente (CONAMA) e incorporada à PNRS, Política Nacional de Resíduos Sólidos.

Em relação ao impacto no processo, o coprocessamento causa maior variabilidade de elementos menores, com consequências nas reações de clinquerização com alterações morfológicas dos cristais de clínquer e modificações nas propriedades que por sua vez influenciam estas reações (tensão superficial, viscosidade). Portanto, o controle de qualidade se tornou mais criterioso para avaliar os efeitos na reatividade do clínquer e desempenho físico-mecânico do cimento.

A análise da reatividade do clínquer engloba avaliação e acompanhamento de variáveis desde o tipo de matéria-prima e combustível, tipo de resíduo usado em um coprocessamento até o controle de operação do forno. Em função disso, as análises químicas e físico-químicas dos insumos em laboratório, as medições de parâmetros da operação do forno e por fim, a análise da composição química, mineralógica e microestrutural do clínquer são fundamentais para o controle de qualidade do processo.

Mediante ao fato supracitado, para uma análise da reatividade do clínquer completa e profunda, não basta caracterização da composição química, deve-se também elaborar caracterizações mineralógicas e microestruturais.

Inúmeras variáveis atuam no processo de produção do clínquer tornando muito difícil definir exatamente quais são as principais variáveis. Uma metodologia estatística importante para o estudo dos processos é a Análise dos Componentes Principais, normalmente associada à sua sigla, em inglês, PCA (Principal Components Analysis). Através deste método, é possível verificar os parâmetros (variáveis) de maior representatividade no sistema do forno de clínquer que podem 
impactar de forma significativa a sua reatividade. Consequentemente, o controle de qualidade se torna mais criterioso, utilizando uma quantidade maior de ferramentas, além de fornecer maior subsídio para tomada de decisões.

\subsection{Objetivo Geral}

Estudar a fabricação do clínquer e do cimento Portland empregando um conjunto reduzido de caracterizações físico-químicas e análise dos componentes principais associados ao processo de produção do clínquer.

\subsection{Objetivos Específicos}

As caracterizações tecnológica e de cunho estatístico dos principais insumos e cimento e do Sistema Forno respectivamente abordam as seguintes técnicas:

- Caracterização da farinha, pó de retorno e clínquer por meio da Espectrometria de Fluorescência de Raios-X para análise da composição química.

- Realização de ensaios de difração de raios-X com Método de Rietveld para farinha, pó de retorno e clínquer para avaliar a composição mineralógica e tipos de estruturas cristalinas de silicatos de cálcio: $\mathrm{C}_{3} \mathrm{~S}, \mathrm{C}_{2} \mathrm{~S}, \mathrm{C}_{3} \mathrm{~A}$ e $\mathrm{C}_{4} \mathrm{AF}$.

- Elaboração de ensaios de microscopia ótica do clínquer para caracterizar a forma dos cristais dos seus principais constituintes e suas modificações. Além disso, é possível elaborar o diagnóstico do processo de fabricação do clínquer e por sua vez, possibilita previsões a respeito do desempenho do cimento. 
- Análise multivariada pelo método PCA para verificar as variáveis mais representativas no sistema forno por meio de componentes de entrada: farinha, combustível sólido, resíduos e parâmetros operacionais e componente de saída: clínquer.

- Realização de ensaios de início e final de pega e resistências a compressão nas idades de 1,3,7 e 28 dias conforme normas ABNT 7215 e 16607. 


\section{2 \\ Revisão Bibliográfica}

\subsection{Processo de Fabricação de Cimento}

\subsubsection{Aspectos Gerais}

Basicamente, o processo produtivo é uma combinação de beneficiamento e exploração mineral (calcário e argila), preparação destas matérias-primas para formar o material cru com corretivos para adequação ao controle de qualidade. Posteriormente, segue para aquecimento no sistema do forno rotativo com características de 2,4 a 6 metros de diâmetro e 2 a $4 \%$ de inclinação para formação do clínquer em cerca de $1450^{\circ} \mathrm{C}$, seguido de um resfriamento rápido. Para formação do cimento, é realizada a mistura por meio do sistema de moagem do clínquer, gesso e outros materiais conforme o tipo de cimento. E por fim, a expedição é realizada expedição é realizada com cimento ensacado de $50 \mathrm{~kg}$ ou a granel.

\subsubsection{Tipos de Sistema de Alimentação do forno rotativo}

Os tipos de processo de elaboração de mistura crua para alimentação ao forno rotativo podem ser divididos da seguinte forma: vias úmida, semi-seca e seca.

- Via Úmida

No processo por via úmida, a alimentação do forno é uma pasta que possui um teor de água entre 20 e $40 \%$ e é preparada em tambores lavadores e/ou moagem úmida. Em função disso, o forno deve ter um comprimento suficiente para que haja uma zona de evaporação e calcinação, causando uma elevação do consumo 
específico de calor que varia de 1300 a $1600 \mathrm{kcal} / \mathrm{kg}$ dependendo do teor de água da pasta. Na zona de evaporação, existe uma cortina de correntes (Figura 4) para favorecer a troca térmica entre a pasta e os gases do forno, além da granulação e transporte do material cru. A temperatura dos gases de saída está entre 150 e $180^{\circ} \mathrm{C}$.

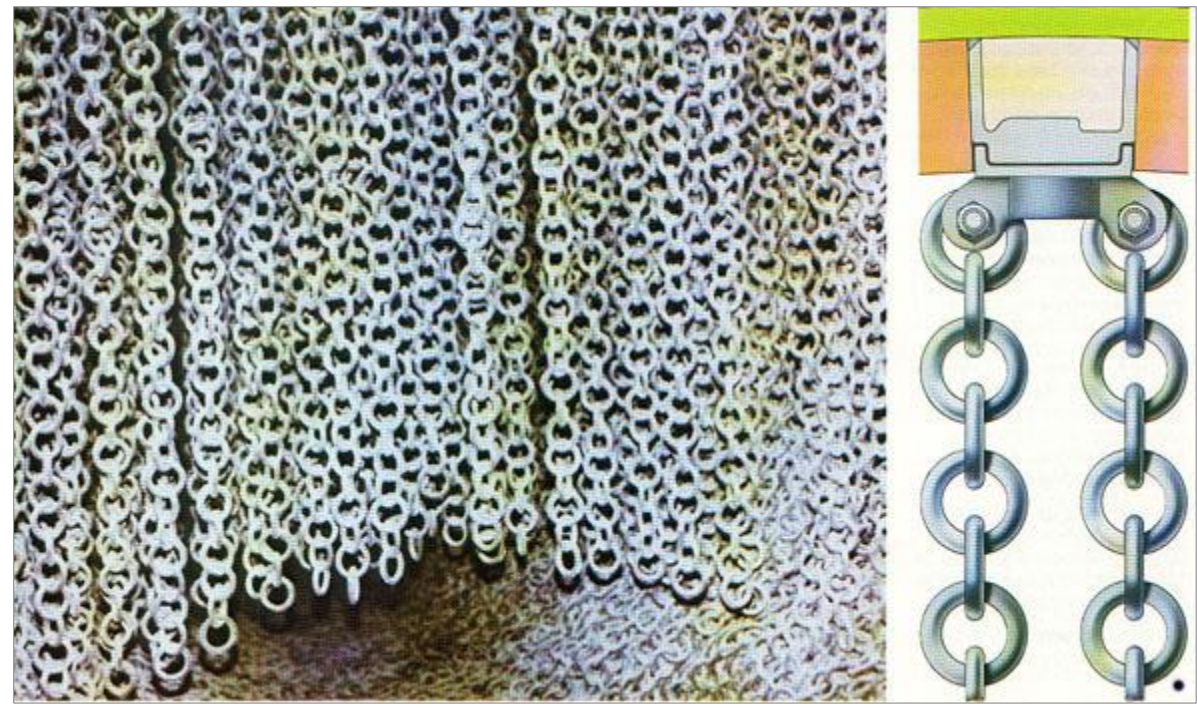

Figura 4-Cortina de correntes

Fonte: Gueiros, 2000

- $\quad \underline{\text { Via Semi-Seca }}$

A mistura crua é umedecida com 10 a $20 \%$ de água para formar nódulos por meio de uma grelha móvel que está sobre o material que fornece um leito através dos gases quentes provenientes do forno. Esta sistemática é realizada em duas passagens. Então, a temperatura dos gases de saída está entre 120 e $180^{\circ} \mathrm{C}$. O consumo específico de calor está entre 800 a 950 kcal/kg (Lea,1998).

\section{- $\quad \underline{\text { Via Seca }}$}

Neste processo a moagem das matérias-primas é realizada a seco, geralmente, com secagem simultânea (utiliza-se os gases quentes de exaustão do forno de clínquer) resultando em uma umidade menor que $1 \%$. Este sistema de alimentação pode ser apenas um pré-aquecedor ou combinado com pré-calcinador. O consumo específico de calor deste processo varia de 700 a $900 \mathrm{kcal} / \mathrm{kg}$ e comparando a via úmida é reduzido praticamente pela metade.

O pré-aquecedor ou este combinado com pré-calcinador é formado por dutos e ciclones como mostrados nas Figuras 5 e 6 respectivamente onde a transferência 
de calor ocorre em fluxo corrente no duto e em direção ao ciclone, contra-corrente (Figuras 7 e 8 respectivamente). Portanto, as partículas ficam em estado de suspensão e a troca térmica com os gases é intensa e rápida.

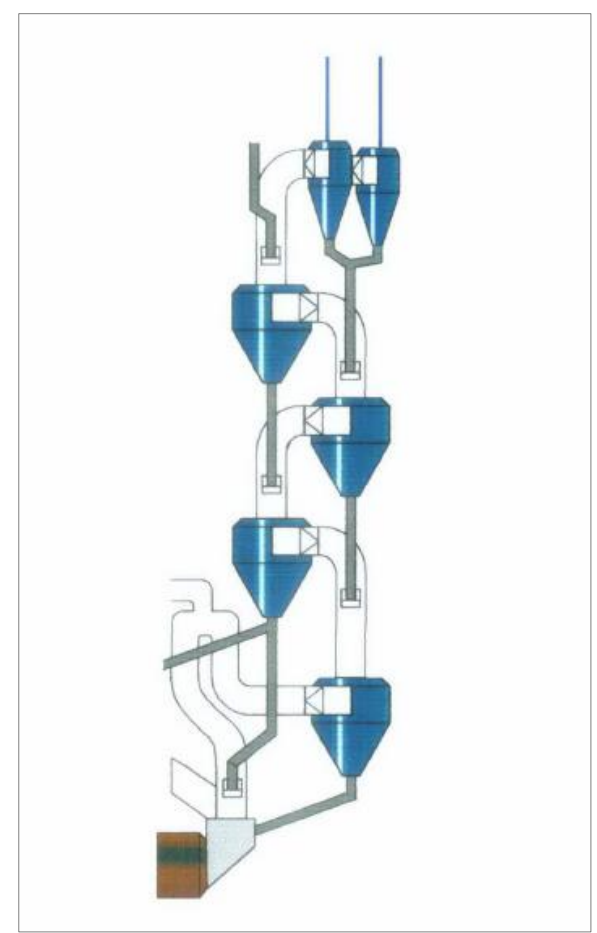

Figura 5-Torre de ciclones

Fonte: Garcia, 2002

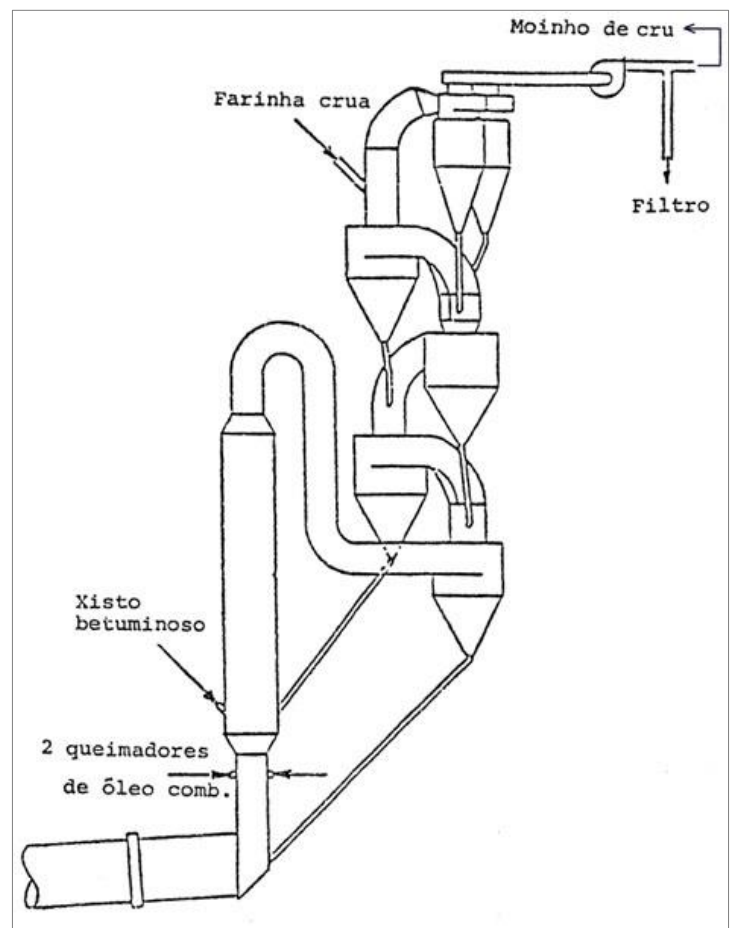

Figura 6-Pré-aquecedor com pré-calcinador Fonte: Gueiros, 2000 


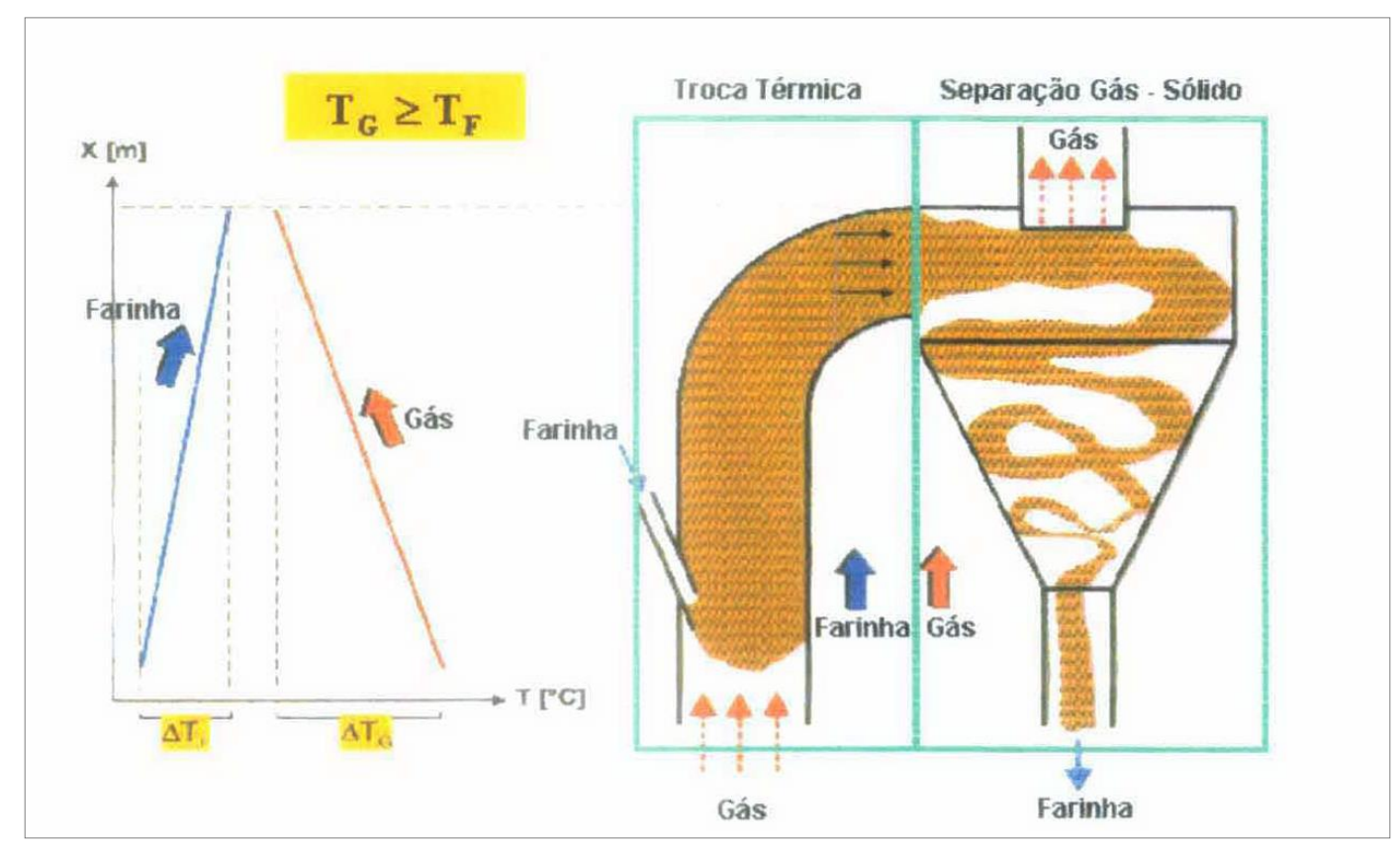

Figura 7- Fluxo corrente

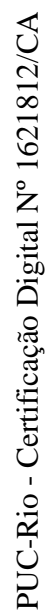

Fonte: Garcia,2003

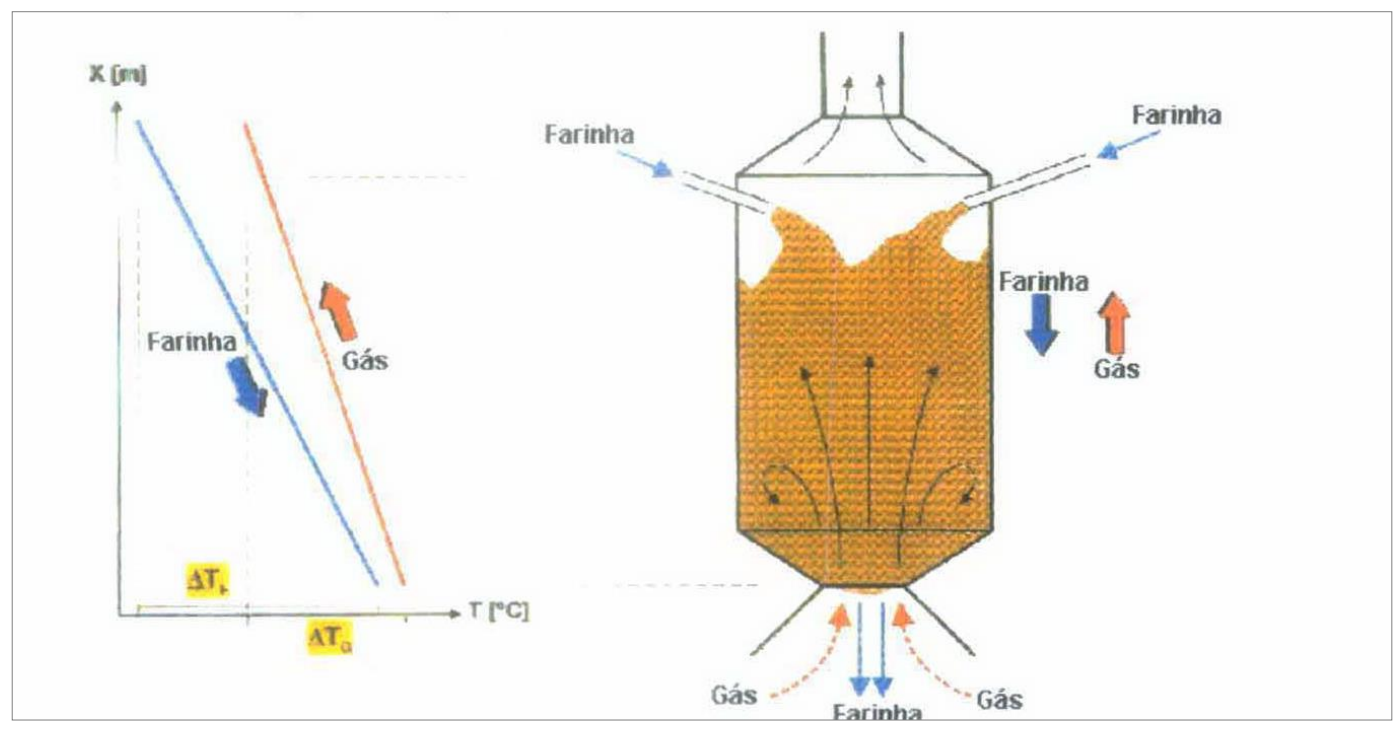

Figura 8-Fluxo contracorrente

Fonte: Garcia,2003 
A Figura 9 exibe uma visão ampla do processo de fabricação de cimento via seca com descrição das etapas e com os principais equipamentos.

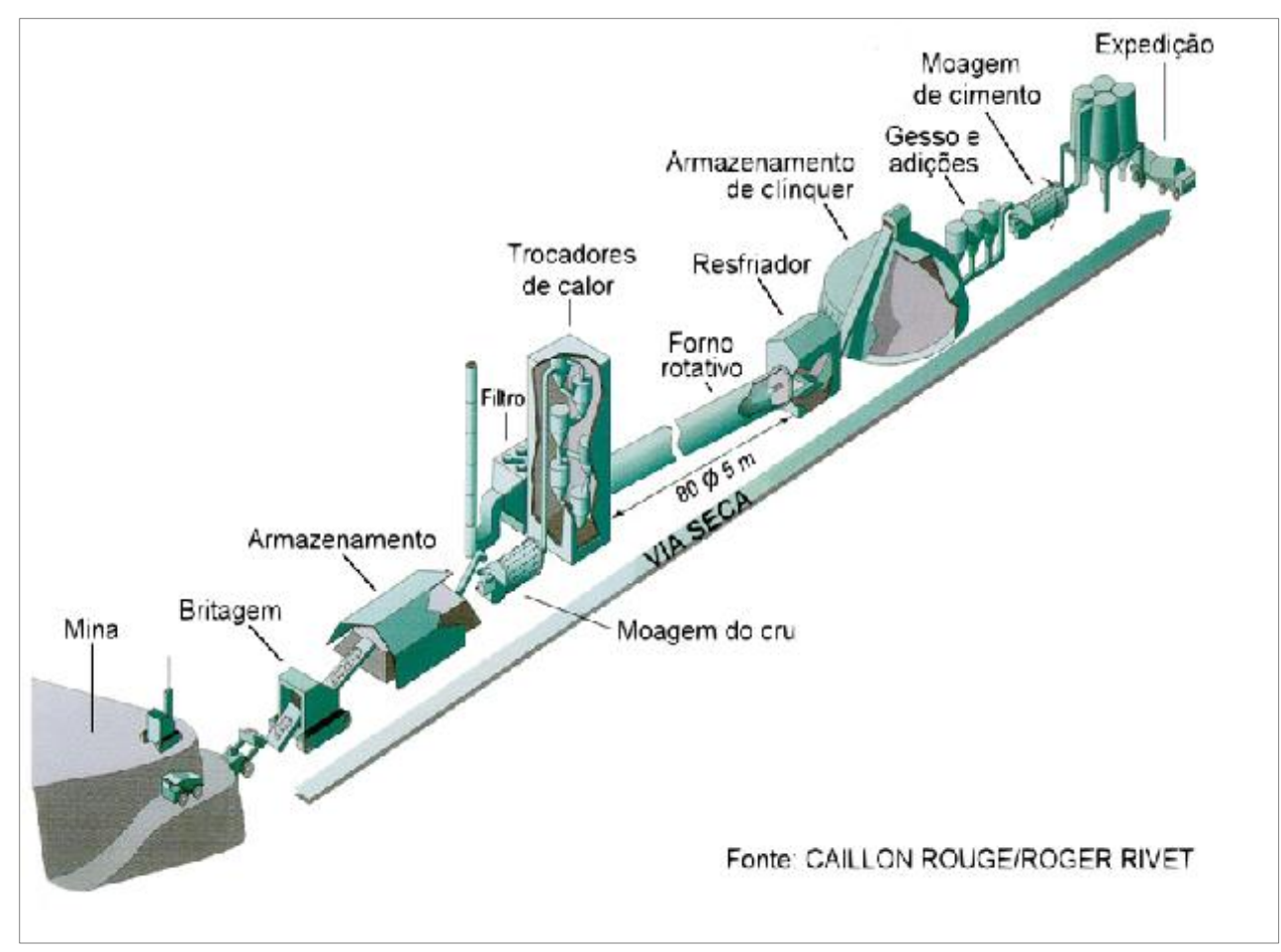

Figura 9-Visão do processo via seco

Fonte: Maringolo, 2001

\subsubsection{Matéria-Prima - Extração, dosagem e preparação}

A exploração das matérias-primas necessárias para indústria cimenteira se inicia com o mapeamento geológico para reconhecimento da área, que consiste na locação de formações e feições geológicas, tais como falhas e dobras indicando também a posição das sondagens e cubagem da jazida. Posteriormente, é realizado um plano de lavra para melhor aproveitamento econômico e estimada a vida útil da mina (Figura 10). Na lavra subterrânea ou a céu aberto são utilizadas perfuratrizes e são usadas técnicas tradicionais de desmonte da rocha por explosivos (calcário de umidade mais baixa) para posterior extração por máquinas pesadas tais como retroescavadeiras e pás carregadeira. Após esta fase, o minério é transportado à usina onde é feito o beneficiamento que em alguns casos consiste de britagem primária, peneiramento, lavagem e separação e cominuição (britagem e/ou moagem) com o objetivo de remover impurezas de forma a adequar a matéria-prima a ser processada na fábrica.( Gueiros, 2000). 


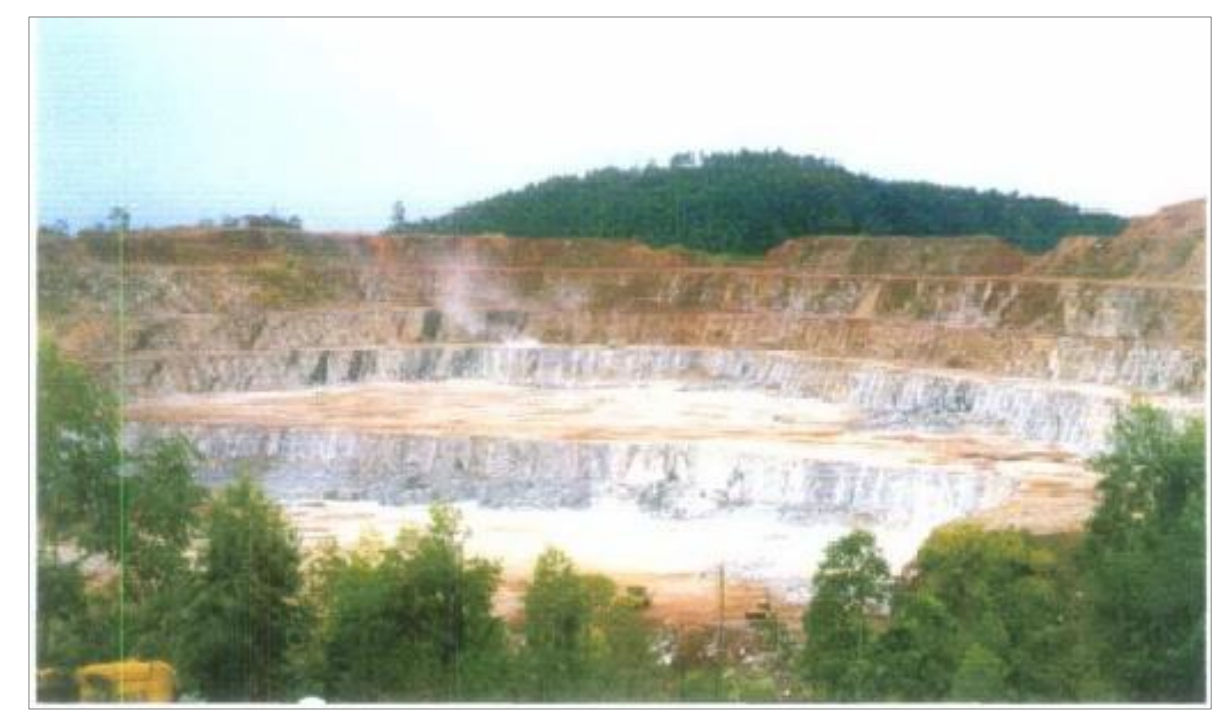

Figura 10-Vista da mina

Fonte: Garcia, 2002

As matérias-primas para fabricação de cimento portland são basicamente compostos minerais contendo os principais componentes do cimento: óxido de cálcio $(\mathrm{CaO})$, óxido de silício $\left(\mathrm{SiO}_{2}\right)$, óxido de alumínio $\left(\mathrm{Al}_{2} \mathrm{O}_{3}\right)$ e óxido de ferro $\left(\mathrm{Fe}_{2} \mathrm{O}_{3}\right)$. Estes minerais não são encontrados na natureza nas quantidades adequadas para obter a matéria-prima (farinha). Então, é necessário dosar com alta quantidade de óxido de cálcio proveniente do calcário e quantidades menores deste contendo maiores quantidades de óxido de alumínio e sílica da argila (Duda, 1975).

Alguns corretivos são usados, como minério de ferro, bauxita ou areia. Por outro lado, alguns calcários argilosos e marlas têm composições próximas a da matéria-prima, porque há uma homogeneidade. A composição química é semelhante a mistura crua do cimento Portland.

Os calcários variam em características físicas de rochas compactas de baixa porosidade (calcita e aragonita) para friável para alta porosidade como greda, que contém no mínimo 25\% de água ou marga (Taylor, 1997). O greda é uma rocha,que ao contrário da calcita ou aragonita, duras tem uma textura leve e se destina ao processo via úmida. Portanto, é dispensada a utilização de explosivos para formar as bancadas na mina e também o britador para redução de granulometria. Já a marga é uma rocha sedimentar geradas simultaneamente por carbonato de cálcio e substâncias argilosas. Em função disso, a dureza da marga é menor que o calcário. Quanto maior o conteúdo de substâncias argilosas, menor a sua dureza (Duda, 1975). 
Nos materiais crus, o componente de óxido de cálcio é geralmente representado por uma quantidade acima de $76-80 \%$. Então as propriedades físicas e químicas deste componente são de influência decisiva que vem a selecionar um método de fabricação de cimento assim como a seleção da máquina de produção (Duda, 1975). Por exemplo, se a matéria-prima for um calcário de alta dureza, então o britador a ser selecionado será o de rolos e não de martelos como mostrado na Figura 11. Porque os martelos terão um alto desgaste o que elevaria os custos da produção com troca intensa destas peças. A Tabela 1 abaixo apresenta os teores de óxido de cálcio das matérias-primas dos tipos de calcário e argila para mistura crua.

Tabela 1 - Teores de $\mathrm{CaO}$ no calcário argila

Fonte: Duda, 1975

\begin{tabular}{cc}
\hline Tipo de calcário & Teor de $\mathrm{CaO}$ \\
\hline Calcário de alto grau & $96-100 \%$ \\
\hline Rocha calcária & $90-96 \%$ \\
\hline Solo rochoso & $75-90 \%$ \\
\hline Marga & $40-75 \%$ \\
\hline Marga argilosa & $10-40 \%$ \\
\hline Argila calcária & $4-10 \%$ \\
\hline Argila & $0-4 \%$
\end{tabular}

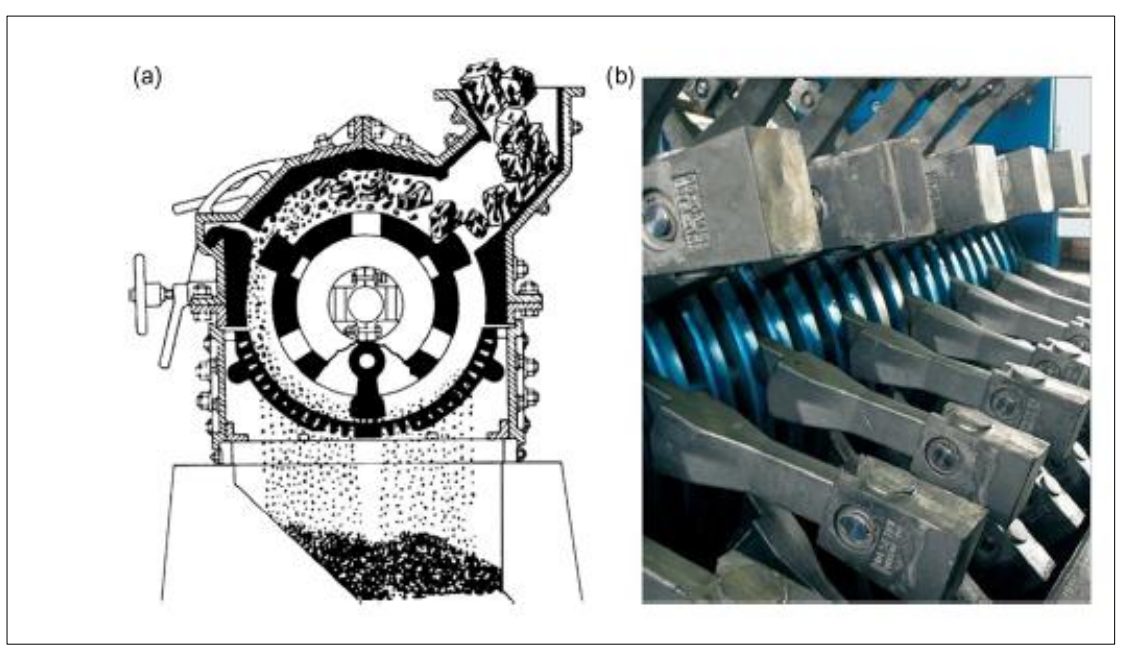

Figura 11-Britador de Martelos

Fonte: Mills,2016 
As argilas são formadas pelo intemperismo do álcali e terra alcalina e dos produtos da conversão química destes, principalmente feldspato e mica. O componente principal da argila é formado por silicatos de alumínio hidratados.

A composição química de argila deve variar desde a argila pura para uma quantidade considerável de misturas químicas como hidróxido de ferro, sulfeto de ferro, areia, carbonato de cálcio, etc. Hidróxido de ferro é o principal agente corante em argilas; também a matéria orgânica deve dar cores diferentes a argila. Argilas sem impurezas são brancas. A maior fonte de álcalis em cimentos é encontrada no componente argiloso do material cru (Duda, 1975). As composições químicas de argilas utilizadas para material cru estão mostradas conforme Tabela 2 a seguir:

Tabela 2 - Composição química de argilas

Fonte: Duda, 1975

\begin{tabular}{ccccc}
\hline Componente $(\%)$ & Argila 1 & Argila 2 & Argila 3 & Argila 4 \\
\hline Perda ao fogo & 7,19 & 8,67 & 10,40 & 6,40 \\
\hline $\mathrm{SiO}_{2}$ & 67,29 & 62,56 & 52,30 & 60,10 \\
\hline $\mathrm{Al}_{2} \mathrm{O}_{3}$ & 8,97 & 15,77 & 24,70 & 18,00 \\
$\mathrm{Fe}_{2} \mathrm{O}_{3}$ & 4,28 & 4,47 & 6,10 & 8,20 \\
\hline $\mathrm{CaO}$ & 7,27 & 4,80 & 4,40 & 0,80 \\
\hline $\mathrm{MgO}$ & 1,97 & 1,38 & 0,10 & 0,20 \\
\hline $\mathrm{SO}$ & 0,32 & - & 1,10 & 3,80 \\
\hline $\mathrm{K}_{2} \mathrm{O}$ & 1,20 & 2,35 & 0,80 & 2,50 \\
\hline $\mathrm{Na}_{2} \mathrm{O}$ & 1,51 & 2,35 & 0,80 & 2,50 \\
\hline Soma - Total & 100,00 & 100,00 & 99,90 & 100,00 \\
\hline
\end{tabular}

Durante um longo tempo, o cimento Portland foi fabricado na base da experiência prática adquirida do processo de produção. Quando foi realizada a comparação das análises químicas do cimento foram encontradas certas relações existentes entre as percentagens de óxido de cálcio por um lado e a combinação de óxido de silício, de alumínio e de ferro por outro (Duda, 1975)

Posteriormente, as relações desses óxidos serviram de base para elaboração de cimentos de boa qualidade. Não há como fornecer dados com alta exatidão 
devido a interferência de outros insumos como as cinzas de combustíveis. Portanto, são utilizadas faixas de trabalho para orientação de alcance dos melhores resultados. Os módulos químicos mais usados são apresentados na Tabela 3.

Tabela 3 - Módulos químicos

Fonte:Gueiros, 2003

\begin{tabular}{lcc}
\multicolumn{1}{c}{$\begin{array}{c}\text { Módulos } \\
\text { Químicos }\end{array}$} & Equações & $\begin{array}{c}\text { Valores } \\
\text { usuais }\end{array}$ \\
\hline $\begin{array}{l}\text { Fator de } \\
\text { saturação de } \\
\text { cal }\end{array}$ & $F S C=\frac{100 \mathrm{CaO}}{2.8 \mathrm{SiO}_{2}+1.2 \mathrm{Al}_{2} \mathrm{O}_{3}+0.65 \mathrm{Fe}_{2} \mathrm{O}_{3}}$ & $\begin{array}{c}90-95 \% * \\
95-98 \% * *\end{array}$ \\
\hline $\begin{array}{l}\text { Módulo de } \\
\text { sílica }\end{array}$ & $\mathrm{MS}=\frac{\mathrm{SiO}_{2}}{\mathrm{Al}_{2} \mathrm{O}_{3}+\mathrm{Fe}_{2} \mathrm{O}_{3}}$ & 1,9 a 3,2 \\
\hline $\begin{array}{l}\text { Módulo de } \\
\text { alumina }\end{array}$ & $\mathrm{MA}=\frac{\mathrm{Al}_{2} \mathrm{O}_{3}}{\mathrm{Fe}_{2} \mathrm{O}_{3}}$ & 1,5 a 2,5 \\
\hline
\end{tabular}

Cimento Portland Comum

**Cimento de Alta Resistência Inicial

Após a dosagem da matéria-prima, estas são transportadas para moegas para serem alimentadas aos moinhos que geralmente são os de bolas de forma a serem cominuídos. No sistema de moagem, existem separadores de alta eficiência que atuam como classificadores de partículas, ou seja, separa o material fino do grosso. No intuito de ter maior proveito do sistema, estes são em circuito fechado para que o grosso seja cominuído até atingir a finura adequada. O material muito fino é arrastado pelo exaustor do filtro de mangas. Posteriormente, a etapa de cominuição da matéria-prima que passa a ser um pó fino este é transportado até os silos de homogeneização onde existem compressores que proporcionam um insuflamento de ar a alta pressão para causar um turbilhonamento.

\subsubsection{Combustíveis}

Ao longo do tempo, a indústria cimenteira tem utilizado combustíveis nos estados sólido, líquido e gasoso, e os critérios de decisão levam em conta questões econômicas, ambientais, disponibilidade e logística.

Anteriormente aos dois choques de petróleo nos anos de 1970, a indústria brasileira também utilizava o óleo combustível cru importado. Após a desestabilização no mercado com a alta de preços do óleo, o Governo Brasileiro implementou uma política de substituição energética por meio de incentivos e subsídios para utilização do carvão mineral, do carvão vegetal ou no emprego da 
energia elétrica nos sistemas de geração de vapor (caldeiras elétricas) ou de calor (fornos, secadores, boilers) (Santi e Filho, 2004).

Em 1979, a indústria brasileira de cimento utilizava óleo combustível para suprir $93 \%$ de suas necessidades de energia para fins térmicos. Com o emprego crescente do carvão mineral nacional e do carvão vegetal, o nível de substituição do óleo combustível atingiu 94,6\% em 1985 que foi bastante intensificada pelas crises internacionais como a Revolução Islâmica no Irã e o conflito Irã/Iraque que novamente elevaram o preço do barril de petróleo. O óleo combustível só voltou a ser utilizado no início da década de 1990 com a queda do preço do barril de petróleo. Em 1995, a matriz energética da indústria do cimento era constituída por cerca de $40 \%$ de óleo combustível, e $20 \%$ distribuídos entre o equivalente entre o carvão mineral e o carvão vegetal e mais o equivalente a $34 \%$ de eletricidade.

A matriz energética voltou a ter uma alteração de forma mais intensa no final dos anos 1990 com a flexibilização do monopólio da Petrobrás entre os combustíveis e a criação da ANP (Agência Nacional de Petróleo). Essas medidas favoreceram a indústria cimenteira para ter acesso ao coque de petróleo, um combustível sólido de elevado poder calorífico e de preços competitivos (Pecchio,2013). A matriz energética da indústria do cimento está mostrada na Figura 12.

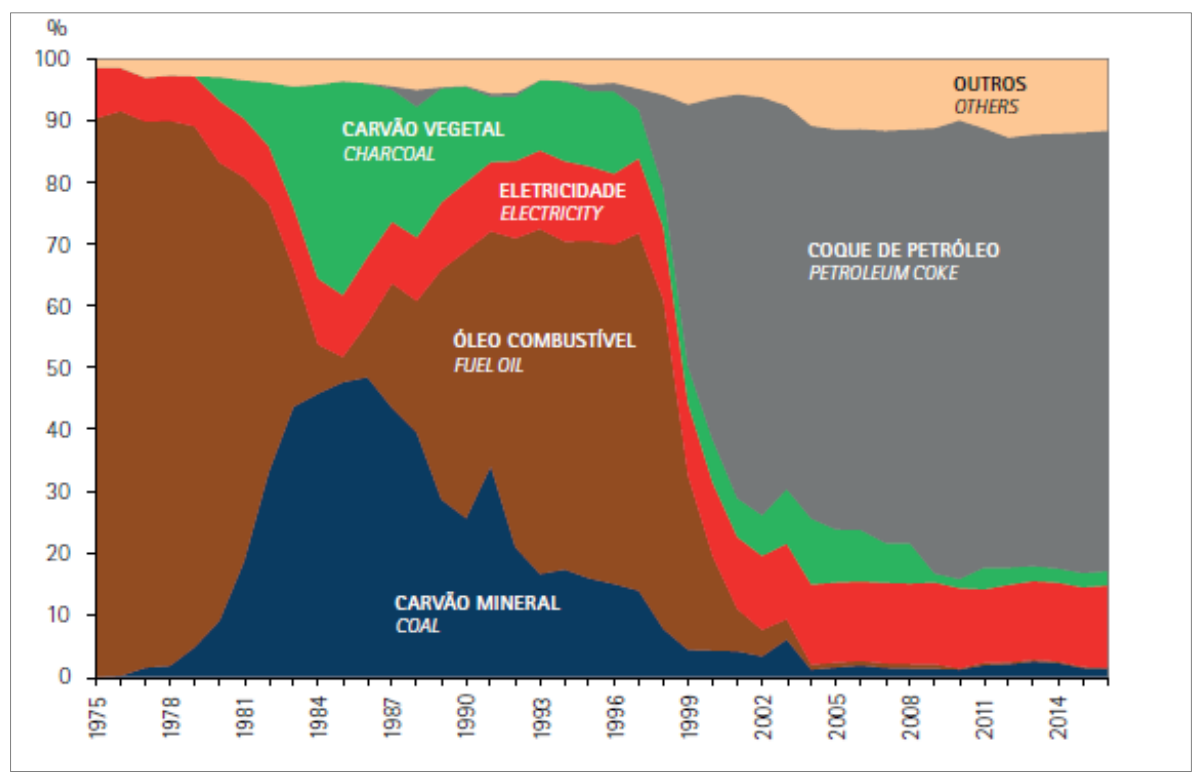

Figura 12- Matriz energética do setor de cimento Fonte: BEN, 2016

O coque mais utilizado pela indústria de cimento vem do Golfo do México, e é produzido pelas refinarias americanas e venezuelanas. Este possui como 
principal característica grande quantidade de asfaltenos, o que lhe confere um aspecto de esferas e elevados teores de enxofre, que expresso na forma de $\mathrm{SO}_{3}$ pode variar de 4 a $6 \%$ em massa. Já o coque de petróleo nacional é produzido pela Petrobrás e se caracteriza pelos conteúdos de enxofre inferior a $1 \%$ em peso (Pecchio, 2013).

\subsubsection{Processo de clinquerização}

As reações de combustão se processam no estado sólido e gasoso, e para que seja eficiente, é necessária alta temperatura, baixo tempo de queima entre a partícula e o ar de combustão, baixo excesso de ar e baixa geração de $\mathrm{CO}, \mathrm{NO}_{\mathrm{x}}$ e $\mathrm{CO}_{2}$. No intuito de chegar a esta eficiência de combustão nas fábricas são utilizadas misturas de combustíveis com foco em propriedades como poder calorífico, teores de umidade, cinza, voláteis e carbono fixo que são determinados os seus valores numa análise imediata. E por fim, para uma análise com maior exatidão do processo de combustão, são determinados os valores de propriedades de oxigênio, nitrogênio e hidrogênio, além dos supracitados. A Tabela 4 mostra algumas propriedades de dois tipos de carvão e coque de petróleo.

Tabela 4 - Propriedades dos combustíveis

Fonte: Peray, 1986

\begin{tabular}{cccc}
\hline Propriedades & Antracito & $\begin{array}{c}\text { Carvão } \\
\text { betuminoso de } \\
\text { média volatilidade }\end{array}$ & $\begin{array}{c}\text { Coque de } \\
\text { petróleo }\end{array}$ \\
\hline Carbono fixo (\%) & 87,7 & 66,8 & - \\
\hline Umidade (\%) & 2,3 & 3,1 & - \\
\hline Cinzas (\%) & 6,9 & 5,1 & 1,2 \\
\hline Voláteis (\%) & 3,1 & 25,0 & 13,0 \\
\hline PCI $(/ \mathrm{kg})$ & 7530 & 7947 & 8119 \\
\hline
\end{tabular}

A origem do volume de ar necessário para a entrada no forno rotativo (Figura 13) é composto basicamente pelo ar primário e secundário. $\mathrm{O}$ ar primário é inserido axialmente e radialmente pelo queimador (Figura 14) de forma a controlar as características da chama e estabilizá-la. Esta também deve ser a mais curta possível para facilitar o controle, a boa qualidade do clínquer e eficiência da 
combustão (Gueiros, 2003). Além disso, a chama deve ter alta temperatura que num forno de operação normal pode atingir a um valor real de $1540^{\circ} \mathrm{C}(\mathrm{Gueiros}, 2003)$.Já o chamado ar secundário é proveniente do resfriador industrial que passa através do leito do clínquer, o ar necessário para combustão é arrastado até o forno pelo exaustor que está localizado na entrada do material cru (Peray,1986). As Figuras 15 e 16 apresentam os tipos de Resfriadores Industriais: grelha e satélite. Já a Figura 17 mostra os formatos de chama.

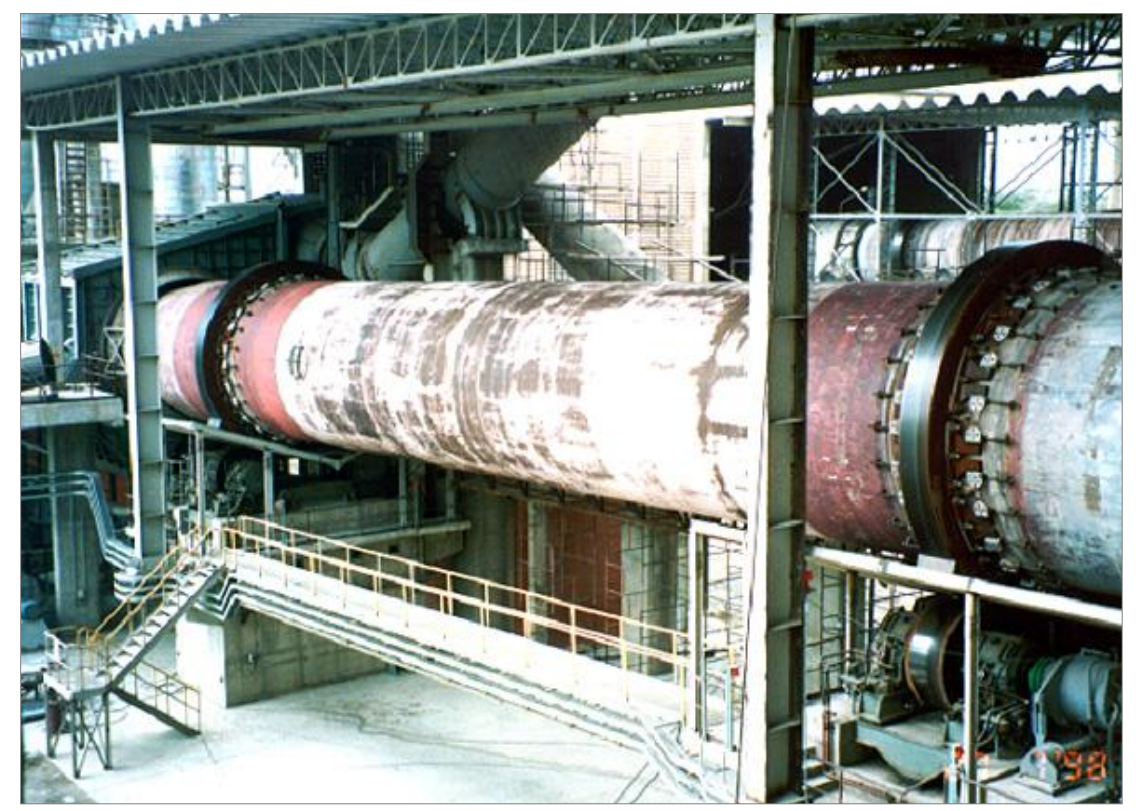

Figura 13- Forno Rotativo

Fonte: Gueiros, 2000

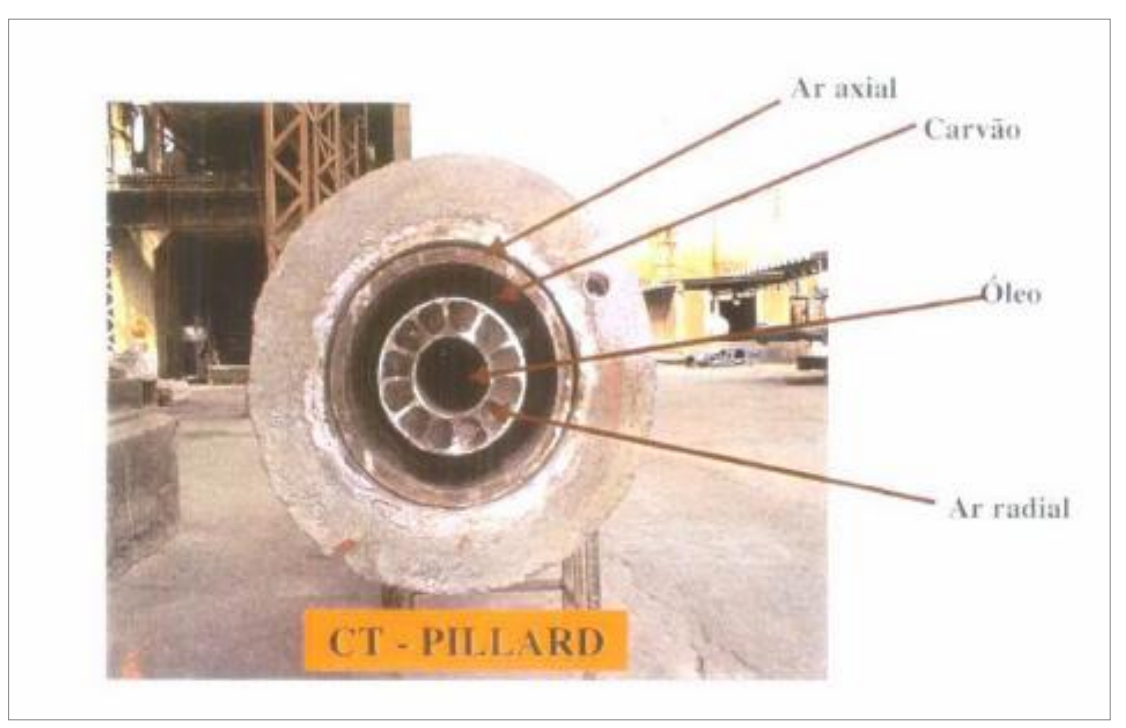

Figura 14-Ponteira do maçarico com as saídas de ar

Fonte: Garcia, 2002 


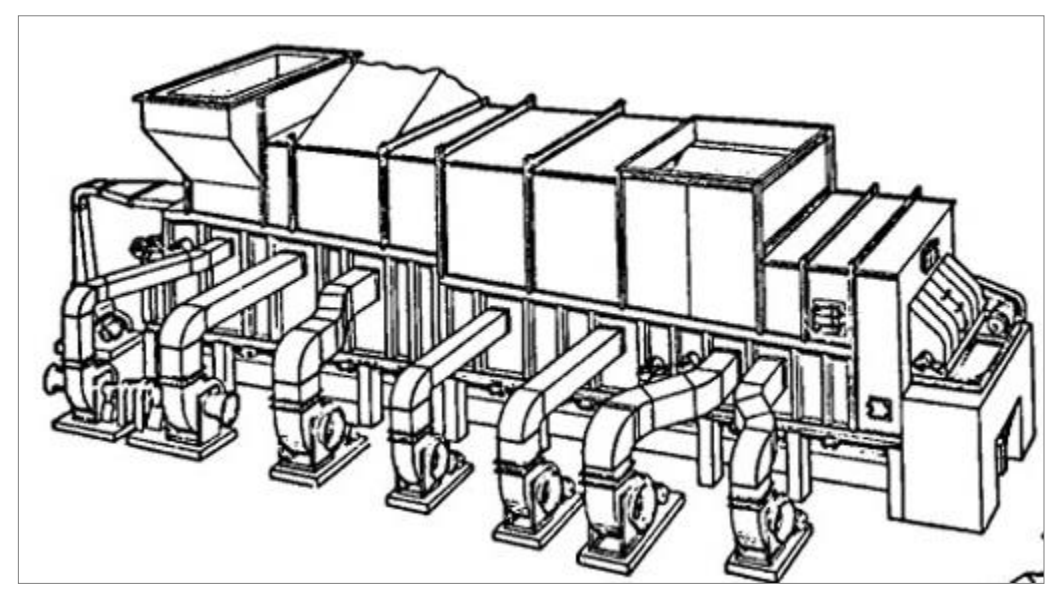

Figura 15-Resfriador tipo grelha

Fonte: Garcia, 2002

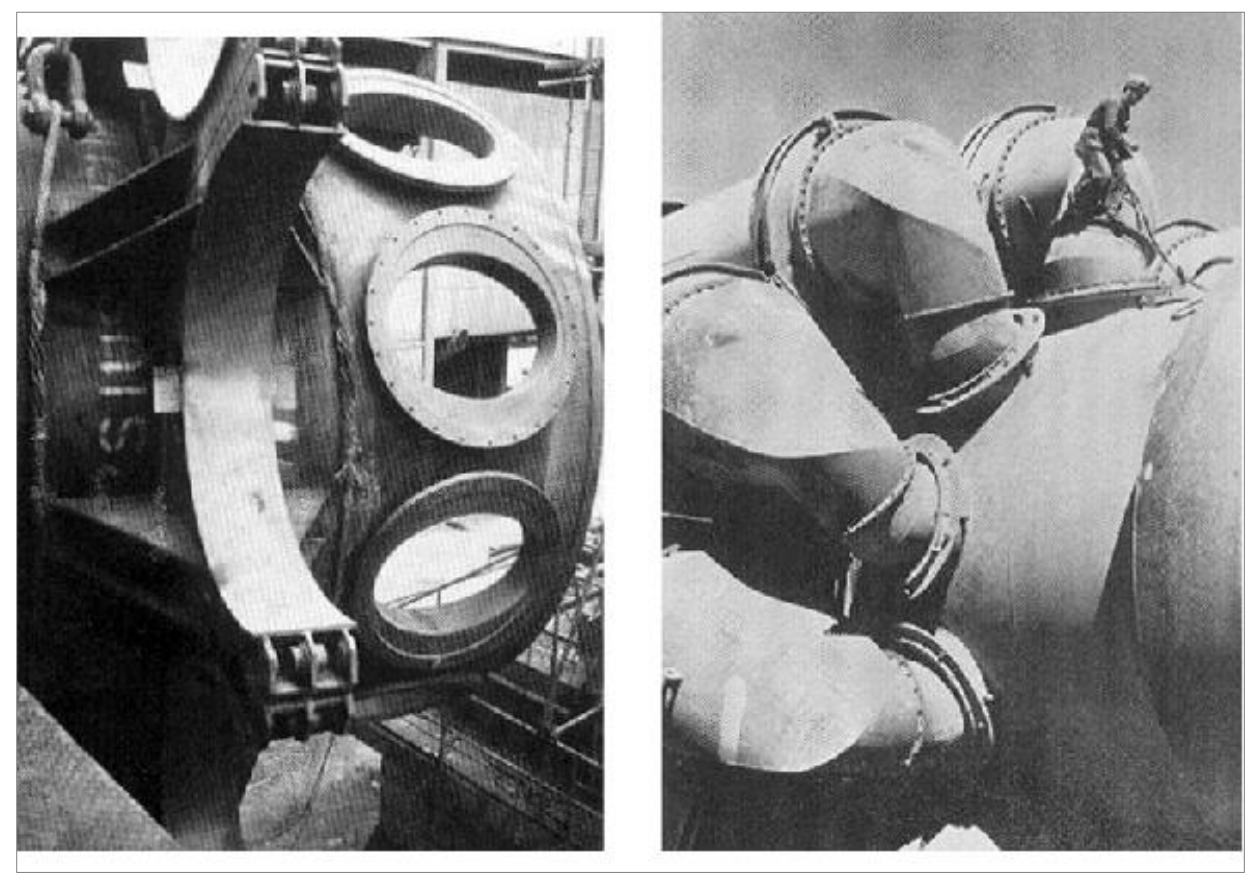

Figura 16-Resfriador tipo satélite

Fonte: Gueiros, 2000

Durante o processo de combustão, os gases da chama transferem seu calor para o ambiente do forno, principalmente por radiação e só uma pequena parte por convecção. Desses gases, $13 \%$ ocupa o volume da farinha, portanto a maior parte do calor transferido vai para o revestimento refratário (Gueiros,2000). 
O movimento da carga do forno não tem velocidade uniforme e não se move em linha reta ao longo do seu eixo pelas zonas (Peray,1986). A extensão relativa das zonas pode, no entanto, mudar variando o perfil de temperaturas ou a composição química do material cru (Garcia, 2002). Estas zonas são mostradas na Figura 17 com suas faixas de temperatura apresentadas pela Tabela 5.

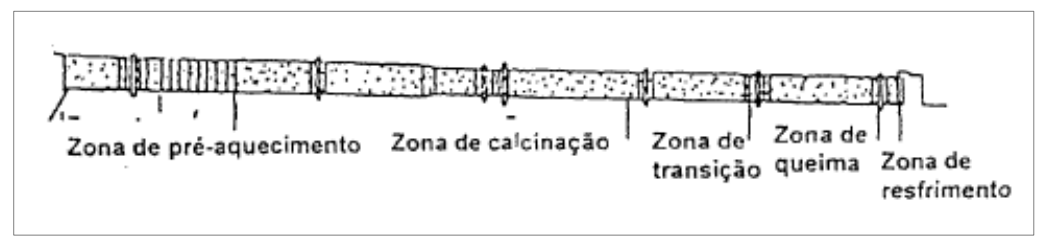

Figura 17-Zonas do forno rotativo

Fonte: Maringolo, 2001

Tabela 5 - Faixas de temperatura das zonas do forno

Fonte: Peray, 1986

\section{Zonas do forno}

Temperatura de reação

\begin{tabular}{cc}
\hline Secagem e pré-aquecimento & $150^{\circ} \mathrm{C}-850^{\circ} \mathrm{C}$ \\
\hline Calcinação & $850^{\circ} \mathrm{C}-1200^{\circ} \mathrm{C}$ \\
\hline Transição superior & $1200^{\circ} \mathrm{C}-1400^{\circ} \mathrm{C}$ \\
\hline Sinterização ou de queima & $1400^{\circ} \mathrm{C}-1510^{\circ} \mathrm{C}$ \\
\hline Resfriamento & $1510^{\circ} \mathrm{C}-1290^{\circ} \mathrm{C}$
\end{tabular}

Na zona de pré-aquecimento, a carga de alimentação avança numa ascensão e queda de acordo com a rotação do forno numa espécie de zig-zag (Peray,1986). A temperatura da carga chega a $805^{\circ} \mathrm{C}$ onde ocorre a evaporação de água livre e reações de desidroxilação de materiais argilosos. No entanto, é possível observar o início da dissociação do carbonato de sódio e de magnésio e a combinação da cal com argila, formando $\mathrm{CaO} \cdot \mathrm{Al}_{2} \mathrm{O}_{3}, 2 \mathrm{CaO} \cdot \mathrm{Fe}_{2} \mathrm{O}_{3}$ e $2 \mathrm{CaO} \cdot \mathrm{SiO}_{2}$ (belita- $\mathrm{C}_{2} \mathrm{~S}$ ). Entre 800 e $900^{\circ} \mathrm{C}$, observa-se o início da formação de $\mathrm{C}_{12} \mathrm{~A}_{7}$. Na faixa de 900 a $1100^{\circ} \mathrm{C}$, ocorre formação e decomposição de $2 \mathrm{CaO} \cdot \mathrm{Al}_{2} \mathrm{O}_{3} \cdot \mathrm{SiO}_{2}$. Inicia-se também a formação de $\mathrm{C}_{3} \mathrm{~A}$ e $\mathrm{C}_{4} \mathrm{AF}$. Grande parte destes constituintes são formados na faixa de $1100^{\circ}$ e $1200^{\circ} \mathrm{C}$. O teor de $\mathrm{C}_{2} \mathrm{~S}$ atinge seu auge nesta fase (Wagner,2004). 
Na zona de transição superior, há uma nova desaceleração na movimentação da carga que está próxima a zona de sinterização. Isto se deve ao fato de que o material cru está num estado semi-líquido (Peray,1986), ou seja, há o início da formação da fase líquida a $1260^{\circ} \mathrm{C}$. Essa constituída por aluminatos e ferro aluminatos cálcicos. Assim, belita $\left(\mathrm{C}_{2} \mathrm{~S}\right)$ e compostos de aluminato e ferrita intermediários $\left(\mathrm{C}_{2}(\mathrm{~A}, \mathrm{~F})\right)$ são mais intensamente formados.

$\mathrm{Na}$ zona de sinterização, a alimentação que está no estado semi-líquido passa a viscoso e passa por uma ação de casqueamento similar ao que ocorre na zona de desidratação (Peray, 1986). Nessa etapa, há a formação dos principais constituintes do clínquer. As reações estão na faixa de $1350-1450^{\circ} \mathrm{C}$, a belita $\left(\mathrm{C}_{2} \mathrm{~S}\right)$ combina com o $\mathrm{CaO}$ livre formando a alita $\left(\mathrm{C}_{3} \mathrm{~S}\right)$. A fase líquida formada aderida às partículas da fase sólida, isto é, pelo processo de coalescência que leva a formação de nódulos cujo tamanho está na faixa de 3-20 mm de diâmetro, sendo que o tempo de reação está em torno de 10-15 minutos (Taylor, 1998). A fase líquida adequada também favorece o transporte de íons, influenciando na cinética da formação dos silicatos cálcicos.

O resfriamento é uma fase extremamente importante na formação, porque este fornece estabilidade às fases e evita a decomposição da alita formada na zona de queima (Kihara et al, 1976).

São considerados dois tipos de resfriamento que têm influências distintas no estudo da composição e da textura mineralógica do clínquer: um que ocorre entre a zona de clinquerização e a boca de saída do forno $\left(1450-1250^{\circ} \mathrm{C}\right)$, e outro que ocorre no resfriador industrial $\left(1250\right.$ até $\left.65^{\circ} \mathrm{C}\right)$ (Kihara et al,1976).

O primeiro resfriamento, quando adequado, condiciona principalmente a estabilidade dos silicatos, ou seja, da alita e belita., além dos outros principais constituintes: $\mathrm{C}_{3} \mathrm{~A}$ e $\mathrm{C}_{4} \mathrm{AF}$. A alita é instável abaixo de $1250^{\circ} \mathrm{C}$ e o espaço de tempo desde o momento de sua formação até o final de resfriamento for longo, a alita inicialmente formada estará em desequilíbrio com a fase líquida a temperaturas mais baixas. A consequência disso, é o ataque da alita pela fase líquida, formando cristais de belita. Quanto ao segundo resfriamento, este condiciona principalmente a cristalização da fase intersticial e do periclásio (Kihara et al,1976).

Quanto aos Resfriadores Industriais, Resfriador de grelhas é o mais eficiente em troca térmica do que o de satélites. O resfriador de grelha além de ocupar $20 \%$ 
de espaço a menos, permite completo controle da temperatura do clínquer e do ar secundário. Para atingir uma temperatura de saída entre 100 e $200^{\circ} \mathrm{C}$, a temperatura de entrada do resfriador de grelha pode estar entre $1350^{\circ} \mathrm{C}$ e $1400^{\circ} \mathrm{C}$ enquanto que no satélite, a temperatura está entre $1100^{\circ} \mathrm{C}$ e $1350^{\circ} \mathrm{C}($ Gueiros,2000).

O processo de formação do clínquer se dá portanto, com as reações ocorrendo entre sólidos e líquidos e sólidos em contato entre si. Bogue (1947) afirma que a velocidade das reações depende fortemente da mudança dos estados dos sólidos com a temperatura ao longo do forno e das condições de estabilidade das redes cristalinas. Assim, os vários tempos de residência são consequências das mudanças físicas e químicas do material que ocorrem durante o processo de queima do forno. A velocidade mais baixa é na zona de queima- $24,3 \mathrm{~cm} /$ minuto- enquanto a velocidade mais alta se dá na zona de calcinação-45,6 cm/minuto (Duda,1975).

O clínquer, este material granular que sai do forno, tem como característica principal, a capacidade de desenvolver uma reação química exotérmica com a água, adquirindo elevada resistência e durabilidade, o que faz dele um ligante hidráulico muito resistente (ABCP, 2003 apud Wagner, 2004).

\subsubsection{Moagem de Cimento: tipos de cimentos e adições}

Após o resfriamento do clínquer, este é transportado até os silos de armazenagem para posteriormente, ser finamente moído. Assim como ocorre na trituração do material cru, os moinhos mais utilizados são os de bolas (Figura 18) com separadores de alta eficiência. O cimento moderno é um material bastante fino, 95\% das partículas possuem dimensão inferior a $45 \mu \mathrm{m}$ e dimensão média de 10 $\mu \mathrm{m}$ (Pecchio, 2013). Em relação à área de superfície específica, os valores variam entre 3000-4500 $\mathrm{cm}^{2} / \mathrm{g}$ conforme tipo de cimento (Taylor, 1997).

O cimento Portland moderno é classificado em comum, composto, alto forno, pozolânico, alta resistência inicial e branco, conforme norma brasileira ABNT NBR 16697 (ABR 2018). Esta classificação é baseada em propriedades úteis para sua aplicabilidade. Para atingir esse objetivo, devem ser atendidos requisitos físicos e químicos fundamentais definidos nesta norma supracitada. Em relação aos requisitos físicos, pode-se destacar a resistência mínima a compressão aos 28 dias que define sua classe e tempo de pega inicial (endurecimento). Já os requisitos 
químicos possuem limites máximos de $\mathrm{MgO}$ e $\mathrm{SO}_{3}$ que estão relacionados a mudança de volume da argamassa e por sua vez do concreto. Este requisito está diretamente relacionado a solidez (Kurdowski, 2014).

O cimento comum se subdivide em sem adição (CPI) e com adição (CPIS). O cimento sem adição pode ter apenas o gesso como aditivo que é fundamental para o controle da pega. A sua aplicabilidade é de uso geral na construção civil e está em desuso devido ao alto custo por ter quantidade elevada de clínquer. Por isso, esse tipo de cimento é quase inexistente no mercado.

Os cimentos compostos são de três tipos de adições ativas: calcário (chamado filler), escória e pozolana. Essas adições minerais participam das reações de hidratação e contribuem para os produtos formados.

As vantagens desses cimentos compostos são uma menor redução de custo em relação ao comum e ao menor calor de hidratação.

O cimento portland composto com calcário (CPII-F32) com adição de 11 a $25 \%$ causa preenchimento entre os grãos do clínquer, favorecendo a moabilidade e tornando o produto mais fino. Isto causa uma aceleração da alita e das fases do aluminato (Taylor,1997).

Já o cimento portland composto com escória granulada de alto forno (CPIIE32), subproduto da produção do ferro gusa, reage mais lentamente que a alita, então o desprendimento de calor é menor. Portanto, a velocidade de evolução de calor em poucas idades e desenvolvimento de resistência é reduzida a medida que há um aumento da proporção de escória na composição do cimento. A adição do cimento composto com escória varia entre 6 e 34\%. A escória com maior adição ao cimento varia entre 35 e $75 \%$ este origina o cimento de alto forno (CPIII).

O cimento Portland composto com escória tem sua aplicabilidade recomendada para estruturas que tenham um desprendimento de calor moderadamente lento ou que possam ser atacados por sulfatos.

São materiais pozolânicos, silicosos ou sílico-aluminosos reagem com água e $\mathrm{Ca}(\mathrm{OH})_{2}$ produzindo silicatos hidratados de cálcio $(\mathrm{C}-\mathrm{S}-\mathrm{H})$. Estes podem ser naturais e artificiais. As primeiras são representadas por cinzas volantes e sílica ativa. As cinzas volantes são resíduos das usinas termoelétricas a carvão típica a Região Sul. Já a sílica ativa, é um subproduto da produção de silício ou ligas de silício pela redução do quartzo no forno elétrico. Quanto às artificiais, estas são denominadas de pozolanas de argilas calcinadas (metacaulim). São provenientes de 
queima de argilas cauliníticas e estão concentradas nas regiões Nordeste e CentroOeste. Dentre as naturais, podem-se destacar tufos e cinzas vulcânicas. A adição de pozolana no cimento composto varia entre 6 e 14\%. A pozolana com maior adição ao cimento varia entre 15 e $50 \%$ este origina o cimento pozolânico (CPIV) (Pecchio, 2013).

Em relação ao cimento pozolânico (CPIV), este é geralmente utilizado para grandes volumes de concreto devido ao baixo calor de hidratação em obras expostas à ação de água corrente e ambientes agressivos, devido a sua baixa porosidade.

Existem tipos de cimentos que se destacam dos demais, que é o caso do $\mathrm{CP}$ V ARI. Este apresenta um rápido desenvolvimento de resistência mecânica e do clínquer Portland branco, elaborado com clínquer com baixo conteúdo de ferro.

O CP V ARI é composto por uma mistura de clínquer com elevado conteúdo de alita e gesso, podendo conter pequenas quantidades de filler calcário. Portanto, esse tipo de cimento possui uma finura mais elevada e desenvolve elevadas resistências a pequenas idades (Pecchio, 2013).

O cimento branco é elaborado com um clínquer "branco". Este é formado em condições ligeiramente redutoras no forno, evitando a formação da ferrita. Além de possuir baixos conteúdos de corantes como cromo e manganês. O rápido resfriamento é importante também para manter incorporados esses elementos na estrutura dos silicatos cálcicos (Taylor, 1997).

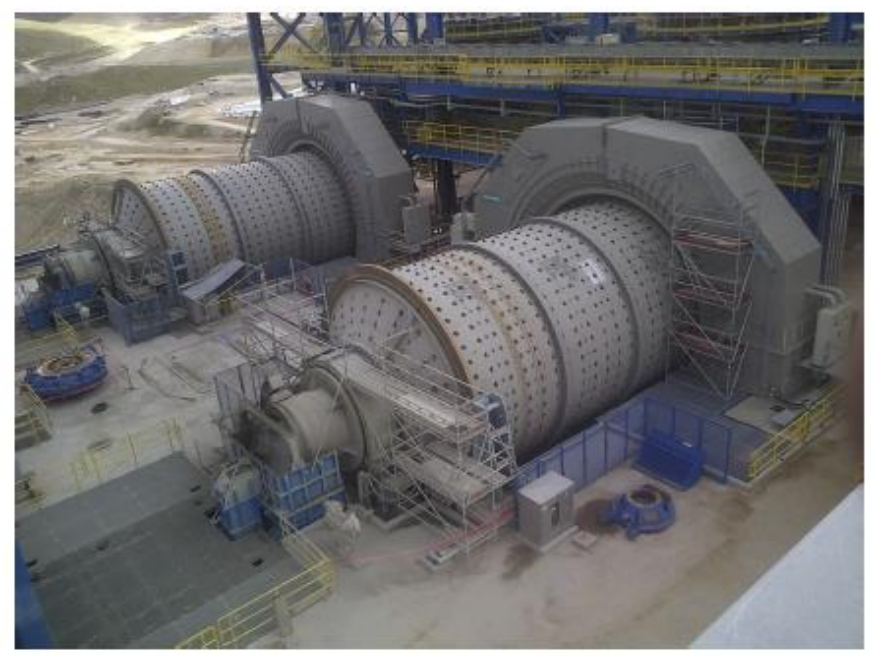

Figura 18- Moinhos de Bolas

Fonte: Wills,2016 


\subsection{Coprocessamento}

\subsubsection{Aspectos Gerais}

A fabricação de cimento Portland tem um impacto significativo ao meio ambiente devido ao consumo de energia de combustível fóssil resultando em geração de particulados e gases de efeito estufa. Dentre estes gases, destaca-se o $\mathrm{CO}_{2}$ cujo gás é o que possui maior pegada de carbono. Em torno de $850 \mathrm{~kg}$ de $\mathrm{CO}_{2}$ são emitidas por tonelada de cimento produzido. A indústria de cimento é responsável por 5-7\% de todas as emissões antropogênicas em todo o mundo (Garcia-Díaz et al,2011).

O coprocessamento tem evoluído bastante devido ao empenho da CSI juntamente com a comunidade científica de forma a minimizar a emissão de gases de efeito estufa na busca tanto do desenvolvimento sustentável como no cumprimento das provisões do Protocolo de Kyoto.

\subsubsection{Panorama do Coprocessamento no Brasil e no Mundo}

De acordo com o programa de sustentabilidade do CSI, há um banco de dados que é possível acompanhar, ano a ano, o desempenho da indústria de cimento brasileira comparativamente aos principais países ou blocos produtores de cimento cuja geração foi fundamental para a criação de 50 indicadores de performance (KPI) (SNIC, 2018). Dentre esses indicadores pode-se destacar o percentual de taxa de substituição do combustível tradicional e emissão específica de $\mathrm{CO}_{2}$ mostrados nas Figuras 19 e 20. 


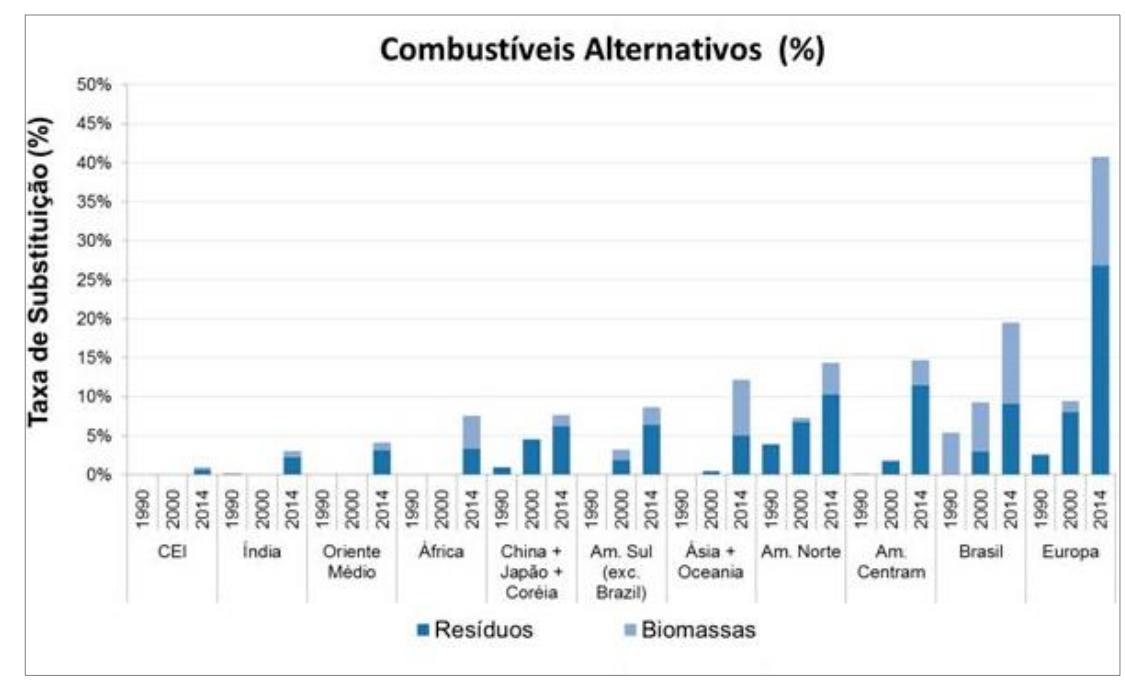

Figura 19- Taxa de substituição

Fonte: CSI apud SNIC, 2018

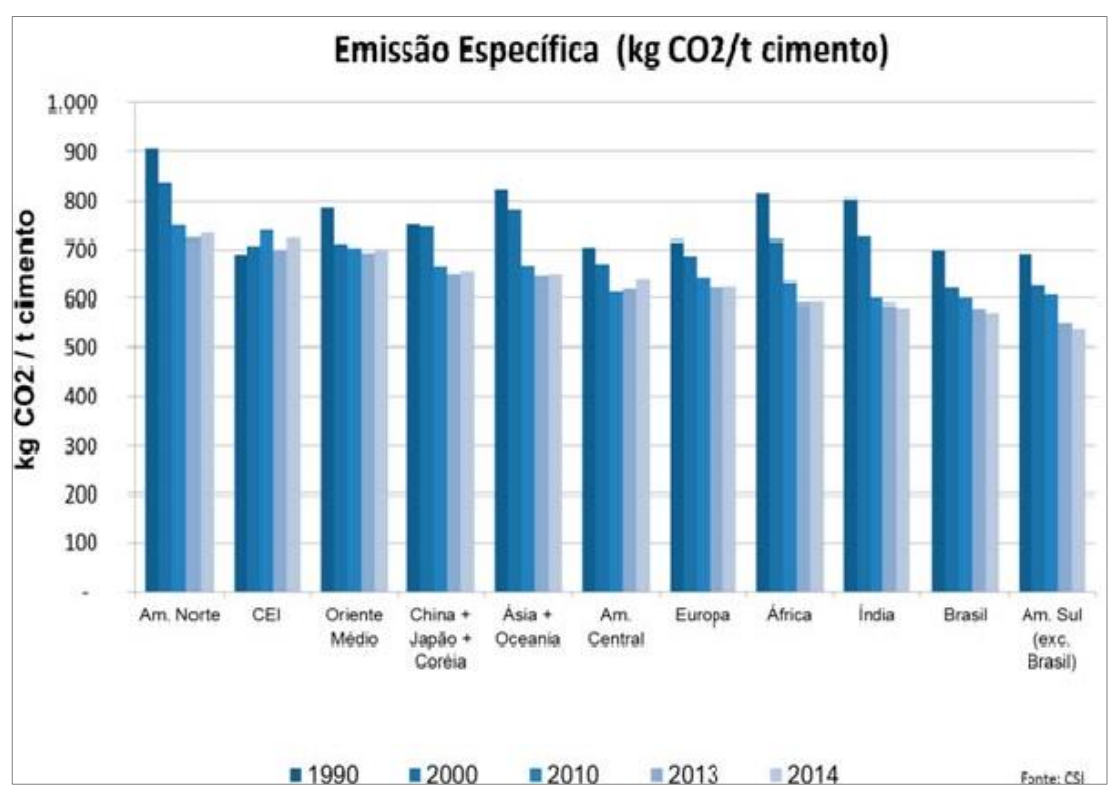

Figura 20- Emissão específica de $\mathrm{CO}_{2}$

Fonte: CSI apud SNIC, 2018

De acordo com a Figura 19, houve um progresso significativo do coprocessamento na indústria nacional, entretanto muito aquém da realidade da Europa. A contribuição dos resíduos na matriz energética está em torno de 9\%. Em 2015, foram processados pela indústria nacional 1,07 milhões de toneladas de resíduos com potencial para queima de 2,5 milhões de toneladas (SNIC, 2018). A Tabela 6 mostra a grande variedade de resíduos que vem sendo destruídos em fornos de clínquer. 
É possível observar na Figura 20 uma redução da emissão específica de $\mathrm{CO}_{2}$ no mundo de uma forma geral em relação aos anos 90. Isso é uma evidência do trabalho da CSI na sustentabilidade ambiental com o apoio do coprocessamento que conduziu a redução do uso de combustíveis fósseis. Muitas produtoras de cimento realizaram investimentos significativos para controle de suas emissões, já que a emissão de $\mathrm{CO}_{2}$ é intrínseca ao processo produtivo, seja com a transformação química da matéria prima em cimento, seja com a queima de combustíveis.

Além disso, há um aproveitamento de subprodutos de outras atividades e matérias-primas alternativas na adição aos cimentos. Esta prática está em desenvolvimento há décadas no país e no mundo de forma que não haja comprometimento na qualidade do produto (SNIC, 2017).

Tabela 6 - Residuos industriais utilizados no coprocessamento

Fonte:ABCP apud Pecchio, 2013

Substitutos de Combustível

\begin{tabular}{ll}
\hline $\begin{array}{l}\text { Resíduos com poder calorífico superior a } \\
\mathbf{2 6 0 0} \mathbf{k c a l} / \mathbf{k g}\end{array}$ & $\begin{array}{l}\text { Resíduos com poder calorífico inferior a } \\
\mathbf{2 6 0 0} \mathbf{k c a l} / \mathbf{k g}\end{array}$ \\
\hline Solventes & Resíduos aquosos \\
\hline Graxas e resíduos oleosos & Água poluída com solventes \\
\hline A Óleos usados (de carro e fábricas) & Água de processos químicos \\
\hline Lama de processos químicos & Água de plantas de pintura \\
\hline Fundos de destilação & Lama derivada de esgoto industrial \\
\hline Resíduos de empacotamento & \\
\hline Resíduos de fábrica de borracha & \\
\hline Pneus usados & \\
\hline Resíduos de picagem de veículos & \\
\hline Resíduos têxteis e plásticos & \\
\hline Serragem & \\
\hline Resíduos de fábrica de papel & \\
\hline Lama de esgoto municipal & \\
\hline Farinha e ossos de animais Seria Combustível & \\
\hline Grãos e sementes de validade vencida & \\
\hline
\end{tabular}




\begin{tabular}{ll}
\hline & Matérias-primas alternativas \\
\hline Lama com alumina (alumínio) & Resíduos da fabricação de vidros (flúor) \\
\hline Lamas siderúrgicas(ferro) & Gesso \\
\hline Areia de fundição (sílica) & Cinzas \\
\hline Terras de filtragem (sílica) & Escória \\
\hline Refratários usados (alumínio) & \\
\hline
\end{tabular}

\subsubsection{Vantagens do co-processamento}

As características do sistema de forno do clínquer junto a tecnologia envolvida no processo de fabricação de cimento quanto ao controle da operação são importantes para o aumento da eficácia na destruição dos resíduos industriais. O perfil de temperaturas no interior do forno rotativo proporciona a eliminação térmica do resíduo de forma a aquecê-lo até a temperatura adequada, além do tempo de retenção necessária para que esta reação ocorra e o fornecimento da quantidade suficiente de oxigênio para eliminá-lo (Maringolo, 2001). Outrossim, pode-se citar abaixo outras vantagens do coprocessamento em fornos de clínquer:

- Altas temperaturas e tempo de residência

- Alta turbulência

- Estabilidade térmica

- Capacidade de absorção das cinzas pelo clínquer sem alterar a qualidade do cimento

- Sistema de despoeiramento de alta eficiência

- Segurança operacional não traz riscos a saúde e segurança aos colaboradores e comunidade (CEMBUREAU, 2009 apud Stafford, et al,2015).

- Contribuição a saúde pública no combate aos focos da dengue com a destruição dos pneus inservíveis (SNIC, 2018).

De acordo com a Resolução CONAMA 264 de 1999, a atividade de coprocessamento em fornos de clínquer é permitida para resíduos, exceto os de origem domiciliares brutos, serviços de saúde, radioativos, explosivos, organoclorados, agrotóxicos e afins. 


\subsubsection{Coprocessamento do resíduo CSS50}

O resíduo sólido CSS50 utilizado por alguns grupos cimenteiros é diversificado de origem vegetal e de derivados de petróleo tais como pedaço de madeira, galho, plástico e óleo. De acordo com a Figura 21, este é inserido na caixa de fumaça localizado entre a saída da torre intercambiadora do forno e sua entrada. É denominado como resíduo sólido grosso.

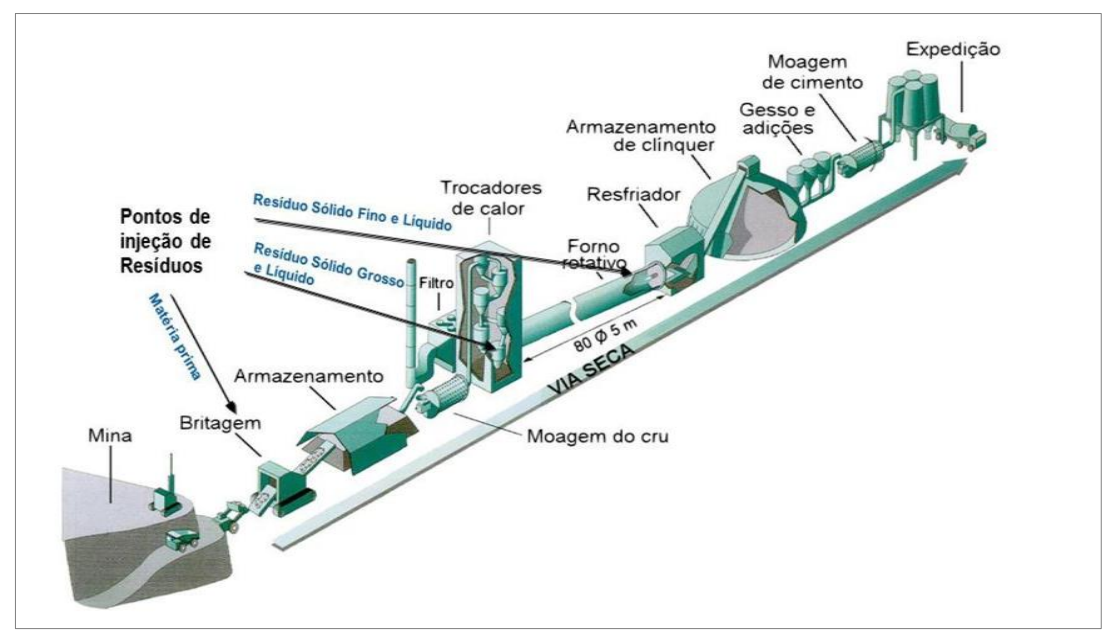

Figura 21- Fluxograma de inserção de resíduos Fonte: Votorantim

\subsection{Mineralogia do clínquer}

O clínquer é composto basicamente de óxidos metaestáveis proveniente do resfriamento rápido, conforme elucidado anteriormente. É constituído de $\mathrm{C}_{3} \mathrm{~S}, \mathrm{C}_{2} \mathrm{~S}$, $\mathrm{C}_{3} \mathrm{~A}$ e $\mathrm{C}_{4} \mathrm{~A}$ que perfazem $90-97 \%$ em massa. Os demais 3-10\% são normalmente constituídos por óxidos de magnésio, álcalis ( $\mathrm{K}$ e $\mathrm{Na}$ ), enxofre e uma grande variedade de elementos menores (Pecchio, 2013). 
A Tabela 7 mostra a faixa de composição do clínquer de cimento Portland (Taylor,1997):

Tabela 7 - Composição do clínquer

Fonte: Taylor,1997

\begin{tabular}{lcc}
\hline \multicolumn{2}{c}{ Composto } & $\begin{array}{c}\text { Percentagem } \\
\text { (peso \%) }\end{array}$ \\
\cline { 1 - 2 } Abreviatura e Nomes químicos & Fórmula Molecular & $50-70 \%$ \\
\hline $\mathrm{C}_{3} \mathrm{~S}$ (alita) - Silicato tricálcico & $3 \mathrm{CaO} . \mathrm{SiO}_{2}$ & $15-30 \%$ \\
\hline $\mathrm{C}_{2} \mathrm{~S}$ (belita) - Silicato dicálcico & $2 \mathrm{CaO} . \mathrm{SiO}_{2}$ & $5-10 \%$ \\
\hline $\mathrm{C}_{3} \mathrm{~A}$ - Aluminato tricálcico & $3 \mathrm{CaO} . \mathrm{Al}_{2} \mathrm{O}_{3}$ & $5-15 \%$ \\
\hline $\mathrm{C}_{4} \mathrm{AF}$ Ferroaluminatotetracálcico & $4 \mathrm{CaO} \cdot \mathrm{Al}_{2} \mathrm{O}_{3} \cdot \mathrm{Fe}_{2} \mathrm{O}_{3}$ &
\end{tabular}

Em menores proporções e dependendo da temperatura de queima, da taxa de resfriamento e da composição química da farinha, poderão se formar as fases cristalinas: cal livre, periclásio e vários sulfatos alcalinos (Pecchio,1997). A Figura 22 apresenta a evolução da mineralogia do clínquer com o aumento da temperatura (Wolter, 1985 apud Garcia, 2002).

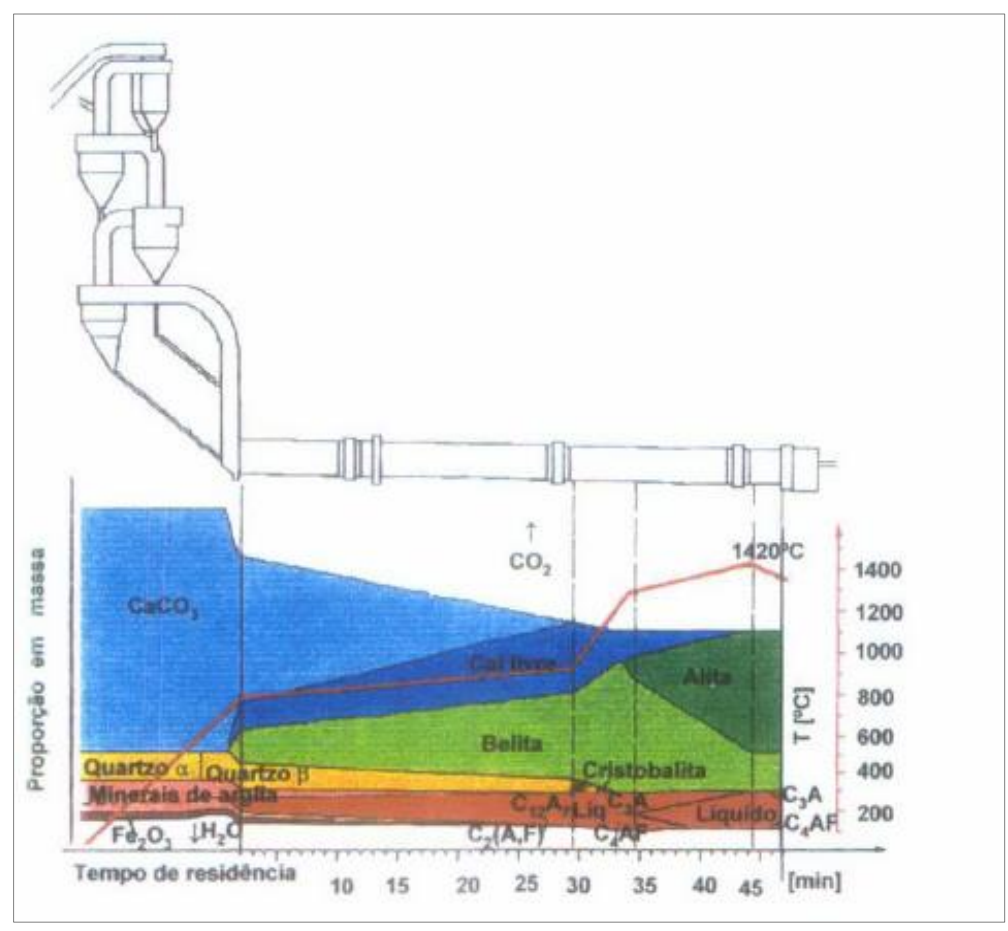

Figura 22-Evolução mineralógica do clínquer

Fonte: Wolter,1985 apud Garcia,2002 
Na reação de formação dos minerais do clínquer, o estado líquido representa aproximadamente $20 \%$ da massa total o que torna necessário a utilização de elevadas temperaturas para promover sua homogeneidade e a obtenção de um equilíbrio entre as fases (Pecchio, 2013).

$\mathrm{O}$ diagrama ternário da Figura 23 se refere ao sistema $\mathrm{CaO}-\mathrm{Al}_{2} \mathrm{O}_{3}-\mathrm{SiO}_{2}$ e traz uma primeira aproximação da evolução mineralógica das principais fases do clínquer com exceção dos compostos de ferro (Pecchio, 2013).

As composições da maior parte dos clínqueres do cimento Portland no sistema $\mathrm{CaO}-\mathrm{Al}_{2} \mathrm{O}_{3}-\mathrm{SiO}_{2}$ podem ser observadas no ponto $\mathrm{P}$ (Figura 24) que está num triângulo cujos vértices são $\mathrm{C}_{3} \mathrm{~S}, \mathrm{C}_{2} \mathrm{~S}$ e um líquido de composição $\mathrm{X}$. Considerando-se o estado de equilíbrio a $1500^{\circ} \mathrm{C}$, é possível predizer quais fases sólidas, ou seja, silicatos que estarão presentes na forma cristalizada após o resfriamento. Quando a composição $\mathrm{P}$ fundida é resfriada, ambos os $\mathrm{C}_{3} \mathrm{~S}$ e $\mathrm{C}_{2} \mathrm{~S}$ cristalizam e a composição química se move ao longo dessa fronteira até a isoterma de $1500^{\circ} \mathrm{C}$ (Taylor, 1997).

De acordo com a composição química do material cru, pode-se ter variações dentro desta região triangular. A composição no ponto $\mathrm{Q}$ representa, nas mesmas condições de equilíbrio a $1500^{\circ} \mathrm{C}, \mathrm{C}_{2} \mathrm{~S}$ cristalizado e um líquido na composição entre X e Y. Quanto ao ponto $\mathrm{R}$, este representa o $\mathrm{C}_{3} \mathrm{~S}$ cristalizado e um líquido na composição entre $\mathrm{X}$ e Z J Já o ponto $\mathrm{S}$, indica $\mathrm{C}_{3} \mathrm{~S}$ cristalizado e mais cal livre devido ao excesso de cal (Taylor, 1997).

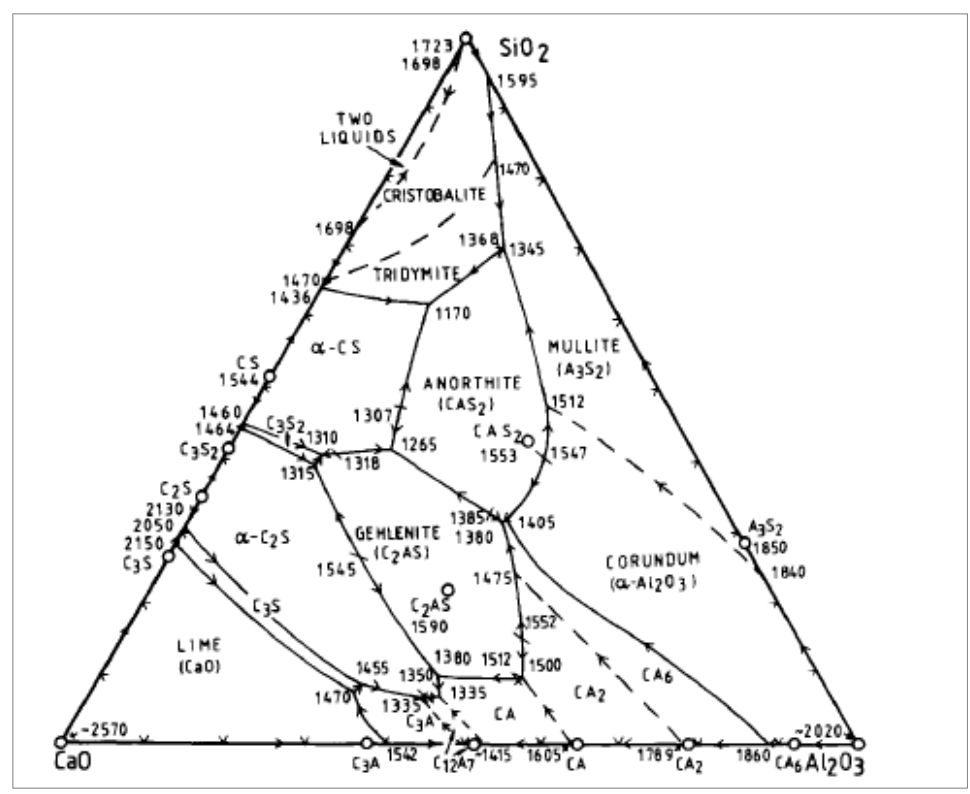

Figura 23-Sistema $\mathrm{CaO}-\mathrm{Al}_{2} \mathrm{O}_{3}-\mathrm{SiO}_{2}$ 
Fonte: Taylor, 1997

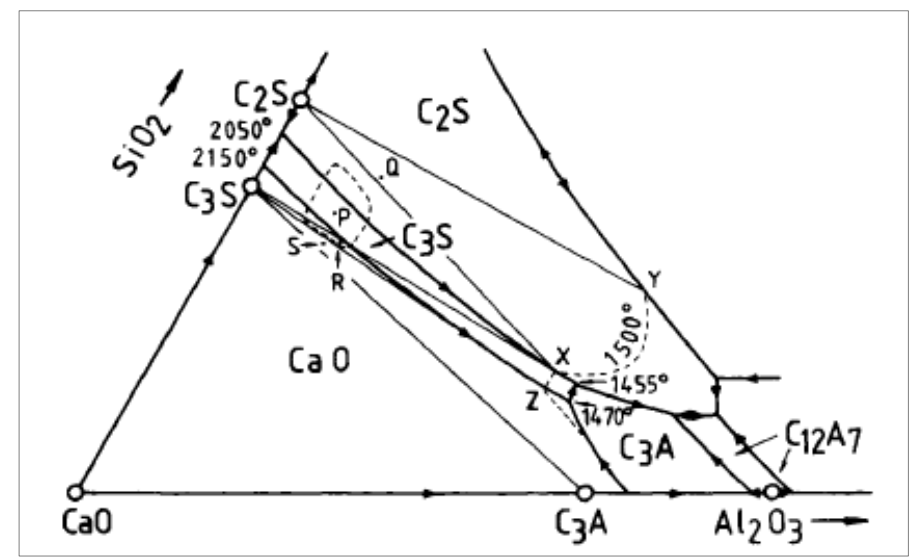

Figura 24-Detalhe do sistema $\mathrm{CaO}-\mathrm{Al}_{2} \mathrm{O}_{3}-\mathrm{SiO}_{2}$

Fonte: Taylor, 1997

\subsubsection{Alita ou silicato tricálcico $\left(\mathrm{C}_{3} \mathrm{~S}\right)$}

Alita é o constituinte mais importante de todos os clínqueres de cimentos e compõe 50-70\% em massa. É silicato tricálcico $\left(\mathrm{Ca}_{3} \mathrm{SiO}_{5}\right)$ modificado na composição e estrutura cristalina por substituições iônicas. Os cristais são idiomórficos, vítreos, compactos e normalmente hexagonais. O tamanho dos cristais está entre 25 e $65 \mu \mathrm{m}$ e a densidade está entre 3,13 e 3,22 mg/m³ (Campbell, 1999).

Este cristal reage relativamente de forma rápida com a água de forma a liberar alto calor de hidratação e em cimentos Portland, é o mais importante das fases constituintes para desenvolvimento de resistência para todas as idades; incluindo idades acima de 28 dias (Taylor, 1997).

$\mathrm{O} \mathrm{C}_{3} \mathrm{~S}$ puro contém $73,7 \%$ de $\mathrm{CaO}$ e 26,3 de $\mathrm{SiO}_{2}$. As alitas em clínqueres tipicamente contém 3-4\% de óxidos substitutos. Os mais importantes substituintes são $\mathrm{Na}^{+}, \mathrm{K}^{+}, \mathrm{Mg}^{+2}$ e Fe ${ }^{+3}$ para $\mathrm{Ca}^{+2}$, e de $\mathrm{Al}^{+3}, \mathrm{P}^{+5} \mathrm{e} \mathrm{S}^{+6}$ para Si+ ${ }^{4}$ (Taylor, 1997).

As primeiras determinações da estrutura de cristal de alita foram realizadas por Jeffery (1952). Ele mostrou que as formas agora conhecidas como R (romboédrica), $\mathrm{T}_{1}$ (triclínica) e $\mathrm{M}_{3}$ (monoclínica), são consideradas similares (Tabela 8) e determinou a forma pseudoestrutural ou aproximada de todos os três. Essa estrutura é construída a partir de íons de $\mathrm{Ca}^{+2}, \mathrm{SiO}_{4}{ }^{-4}$ e $\mathrm{O}^{-2}$, estes últimos ligados somente aos seis íons $\mathrm{Ca}^{+2}$, como no $\mathrm{CaO}$ (Taylor, 1997). 
Posteriormente, outros autores (Maki apud Centurione e Kihara) estabeleceram que o silicato tricálcico puro pudesse assumir a seguinte sequência de transições polimórficas reversíveis apresentadas pela Tabela 8 quando aquecido a partir da temperatura ambiente até sua fusão.

Tabela 8 - Polimorfismo da alita

Fonte: Taylor, 1997

\begin{tabular}{cc}
\hline Fase polimórfica & $\begin{array}{c}\text { Temperatura de Conversão } \\
\left({ }^{\circ} \mathbf{C}\right)\end{array}$ \\
\hline $\mathrm{R}$ & 1070 \\
\hline $\mathrm{M}_{3}$ & 1060 \\
\hline $\mathrm{M}_{2}$ & 990 \\
\hline $\mathrm{M}_{1}$ & 980 \\
\hline $\mathrm{T}_{3}$ & 920 \\
\hline $\mathrm{T}_{2}$ & 620 \\
\hline $\mathrm{T}_{1}$ & 20 \\
\hline \multicolumn{2}{c}{$\mathrm{T}_{1} \leftrightarrow \mathrm{T}_{2} \leftrightarrow \mathrm{T}_{3} \leftrightarrow \mathrm{M}_{1} \leftrightarrow \mathrm{M}_{2} \leftrightarrow \mathrm{M}_{3} \leftrightarrow \mathrm{R}$}
\end{tabular}

Onde T=triclínico, $\mathrm{M}$ = monoclínico, $\mathrm{R}=$ romboédrico

De acordo com a Tabela 8, nenhum polimorfo estável a temperatura quando este é resfriado para temperatura ambiente, passa a ser $T_{1}$. Nos clínqueres industriais, devido a incorporação de íons substituintes, a forma presente em temperatura ambiente normalmente se aproxima para $\mathrm{M}_{1}$ ou $\mathrm{M}_{3}$ ou uma mistura dos dois, raramente, $T_{2}$ é encontrado (Taylor, 1997). Então, os diferentes polimorfos são influenciados pelos seguintes fatores, além da temperatura de formação, composição, incorporação de elementos menores e taxa de resfriamento (Maki apud Centurione e Kihara).

As diferenças estruturais entre os polimorfos afetam a coordenação dos íons $\mathrm{Ca}^{+2}$ e os átomos de $\mathrm{O}$ do tetraedro $\mathrm{SiO}_{4}^{-4}$. Para cada polimorfo, há várias posições distintas de $\mathrm{Ca}^{+2}$ com diferentes coordenações, e para uma dada posição, a coordenação poderá variar entre átomos individuais devido a desordem orientacional nas vizinhanças dos tetraedros. Os números de coordenação do Ca são arbitrários, pois estão em função de variações dos comprimentos das ligações, por exemplo: $\mathrm{Na}$ forma $\mathrm{R}$ a $1200^{\circ} \mathrm{C}$, os átomos de $\mathrm{Ca}^{+2} \mathrm{em}$ cada uma das posições pode ser considerada como coordenação 7 quando as ligações possuem comprimento de 
$0,296 \AA$ A enquanto a coordenação é 5 se não tiver este comprimento. O número de coordenação médio do Ca é 5,66 no polimorfo R, 6,15 em $\mathrm{M}_{3}$ e 6,21 em $\mathrm{T}_{1}$ (Taylor, 1997).

Maki e colaboradores (apud Taylor, 1997) estudaram a cristalização da alita utilizando seções delgadas por meio do microscópico ótico de alta temperatura com análises térmica e de difração de Raios-X. A alita se cristaliza como polimorfo $\mathrm{R}$ a aproximadamente $1450^{\circ} \mathrm{C}$ transformando-se em formas de mais baixa temperatura por meio do resfriamento.

Em faixa de temperatura de normal a alta de recristalização, pequenos cristais são formados e há aumento destes com alto conteúdo de íons substituintes que podem se transformar no polimorfo $\mathrm{M}_{3}$ durante o resfriamento até a temperatura ambiente. Já os cristais formados em faixa de temperatura baixa, possuem tamanho grande e são pobres em íons substituintes e podem transformar-se parcial ou completamente no polimorfo $\mathrm{M} 1$, ou raramente para $\mathrm{T}_{2}$.

Os teores de $\mathrm{MgO}$ e $\mathrm{SO}_{3}$ do clínquer são importantes no controle da transformação para $\mathrm{M}_{1}$ (Figura 25). Altas concentrações de $\mathrm{MgO}$ e $\mathrm{SO}_{3}$ favorecem a nucleação ao invés do crescimento, resultando na formação de cristais euhedrais de $\mathrm{M}_{3}$. Por outro lado, baixas concentrações desses constituintes favorecem o rápido e instável crescimento, produzindo cristais grandes e de formas irregulares do polimorfo $\mathrm{M}_{1}$. Esses podem ser esqueletais ou dendríticos com alto conteúdo de inclusões de fase e pequenos cristais de belita e cal livre. Cristais contendo $\mathrm{M}_{3}$ e $\mathrm{M}_{1}$ podem ocorrer e são frequentemente zoneados, com núcleos de $\mathrm{M}_{1}$ e regiões periféricas de $\mathrm{M}_{3}$. $\mathrm{O}$ zoneamento ocorre porque o líquido do clínquer vai progressivamente enriquecendo em $\mathrm{MgO}$ com o decorrer da cristalização fazendo com que o material se deposite tardiamente, seja $\mathrm{M}_{3}$. A transformação de $\mathrm{M}_{3}$ paraM 1 é também influenciada pelas taxas de resfriamento, de modo que resfriamentos lentos favorecem o aparecimento de $\mathrm{M}_{1}$ (Taylor,1997). 


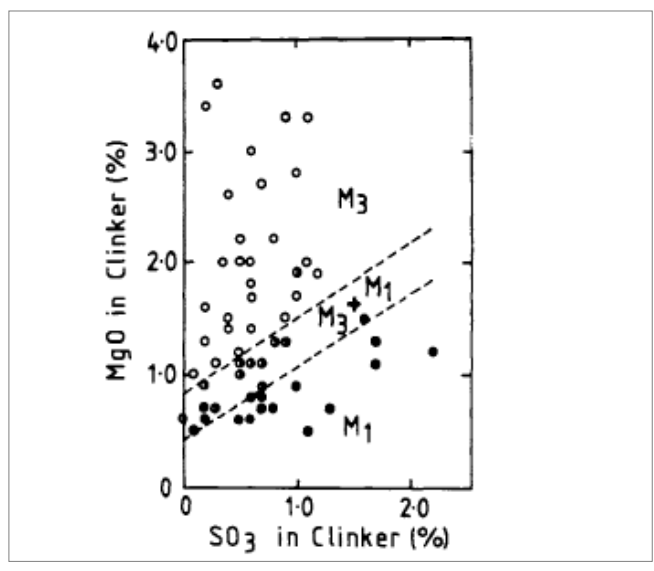

Figura 25-Polimorfos $\mathrm{C}_{3} \mathrm{~S}$ em função de $\mathrm{MgO}$ e $\mathrm{SO}_{3}$

Fonte: Taylor, 1997

Num aquecimento prolongado a altas temperaturas, os grandes cristais de alita crescem a custas dos menores e nesse processo o conteúdo de íons substituintes decresce, favorecendo a transformação de $\mathrm{M}_{3}$ para $\mathrm{M}_{1}$ ou $\mathrm{T}_{2}$. Clínqueres industriais são suficientemente ricos em $\mathrm{MgO}$ para evitar essas transformações, apesar de ocorrer possíveis recristalizações. As recristalizações podem influenciar de forma significativa a relação entre temperatura de formação e tamanho de cristal (Taylor,1997).

A alita como principal responsável pelo desenvolvimento de toda a resistência mecânica no cimento, é o foco principal do controle de qualidade das cimenteiras. Experimentos realizados utilizando métodos como Difratometria de Raios-X ou outros, demonstraram que $70 \%$ dos cristais de alita reagem com a água até os 28 dias e praticamente todos os cristais em 1 ano (Taylor, 1997). Esse processo produz hidróxido de cálcio e um silicato hidratado amorfo, chamado de C-S-H $\left(\mathrm{CaO} \cdot \mathrm{SiO}_{2} \cdot \mathrm{H}_{2} \mathrm{O}\right)$, que possui propriedades similares a de um gel rígido.

\subsubsection{Belita ou Silicato bicálcico( $\left.\mathrm{C}_{2} \mathrm{~S}\right)$}

A belita é o segundo constituinte mais importante dos clínqueres de cimentos Portland e compõe 15-30\% em massa. É silicato bicálcico $\left(\mathrm{Ca}_{2} \mathrm{SiO}_{5}\right)$ modificado por substituições iônicas e normalmente presente como o polimorfo $\beta$. Os cristais são idiomórficos, vítreos e normalmente arredondados. O tamanho está entre 1 e $4 \mu \mathrm{m}$ abaixo de $1300^{\circ} \mathrm{C}$, mas recristaliza a alta temperatura (aproximadamente $1500^{\circ} \mathrm{C}$ ). A densidade da belita é 3,07 Mg/m 3 (Campbell,1999) 
Este cristal reage de forma mais lenta com a água de forma que há liberação de menor calor de hidratação em relação ao $\mathrm{C}_{2} \mathrm{~S}$. Há pouca contribuição para a resistência durante os primeiros 28 dias, mas aumenta substancialmente as resistências em longas idades. De acordo com experimentos com a Difratometria de Raios-X e outros métodos, $30 \%$ dos cristais de $\mathrm{C}_{2} \mathrm{~S}$ reagem durante os primeiros 28 dias e até $90 \%$ em 1 ano (Taylor, 1997).

$\mathrm{O}_{2} \mathrm{~S}$ puro contém $65,1 \%$ de $\mathrm{CaO}$ e $34,9 \%$ de $\mathrm{SiO}_{2}$. As belitas em clínqueres contém tipicamente $4-6 \%$ de óxidos substitutos. Normalmente, os principais substitutos são $\mathrm{Al}_{2} \mathrm{O}_{3}$ e $\mathrm{Fe}_{2} \mathrm{O}_{3}$.

As análises térmicas e de Difração ou Fluorescência de Raios-X mostram cinco polimorfos de $\mathrm{C}_{2} \mathrm{~S}$ existentes em pressões ambientes como podem ser vistas na Tabela 9 .

Tabela 9 - Polimorfismo da belita

Fonte: adaptado de Taylor,1997

\begin{tabular}{cc}
\hline Fase polimórfica & $\begin{array}{c}\text { Temperatura de Conversão } \\
\left({ }^{\circ} \mathbf{C}\right)\end{array}$ \\
\hline$\alpha$ & 20 \\
$\alpha_{\mathrm{H}}$ & 1425 \\
$\alpha_{\mathrm{L}}$ & 1160 \\
$\beta$ & $630-680$ \\
$\gamma$ & $\alpha \leftrightarrow \alpha_{\mathrm{H}} \leftrightarrow \alpha_{\mathrm{L}} \leftrightarrow \beta \leftrightarrow \gamma$ \\
\hline
\end{tabular}

As estruturas de todas as fases são constituídas de íons $\mathrm{Ca}^{+2}$ e $\mathrm{SiO}_{4}{ }^{-2}$. Os arranjos desses íons são aproximadamente similares nos polimorfos $\alpha, \alpha_{\mathrm{H}}^{\prime}, \alpha_{\mathrm{L}}^{\prime}$ e $\beta$, mas o $\gamma-\mathrm{C}_{2} \mathrm{~S}$ é diferente (Taylor, 1997). O $\gamma-\mathrm{C}_{2} \mathrm{~S}$ é muito menos denso e pode levar a pulverização do clínquer, pois sua transformação ocorre com um aumento de volume de $13 \%$. Além disso, o $\gamma-\mathrm{C}_{2} \mathrm{~S}$ resulta em um composto de baixíssima reatividade hidráulica. Como os clínqueres industriais têm incorporação de elementos menores que atuam de forma estabilizadora, raramente há a transformação do $\beta-C_{2} S$ para a forma $\gamma-C_{2} S$ (Shukuzawa, 1986). 
A forma cristalográfica do $\mathrm{C}_{2} \mathrm{~S}$ varia de acordo com a velocidade de resfriamento entre $1400^{\circ} \mathrm{C}$ e $1000^{\circ} \mathrm{C}$. À medida que o resfriamento se processa, a forma $\alpha$ de mais alta temperatura passa a $\alpha$, estabilizando finalmente na forma $\beta$, que é a normalmente encontrada no clínquer. Hidraulicamente, a forma $\alpha$ é a mais reativa, razão pela qual este autor considera que clínqueres resfriados rapidamente tendem a apresentar maiores resistências mecânicas. Os cristais arredondados obtidos através de resfriamento rápido são os que mais contêm $\alpha-C_{2} S$, enquanto os cristais digitados, decorrentes de um resfriamento lento, são os formados essencialmente por $\beta-C_{2} S$ (Ono apud Shukuzawa, 1986).

As estruturas dos polimorfos $\alpha_{H}^{\prime}, \alpha_{L}^{\prime}$ e $\beta$ são derivados de $\alpha-C_{2} S$ pela redução progressiva da simetria pelas mudanças na orientação do tetraedro $\mathrm{SiO}_{4}{ }^{-4} \mathrm{e}$ pequenos movimentos de íons $\mathrm{Ca}^{+2}$. Assim como ocorre com a polimorfismo do $\mathrm{C}_{3} \mathrm{~S}$, há uma diferença no número da coordenação do íon $\mathrm{Ca}^{+2} \mathrm{em}$ cada polimorfo. $\mathrm{O} \beta-\mathrm{C}_{2} \mathrm{~S}$, por exemplo, alguns íons $\mathrm{Ca}^{+2}$ têm sete ou oito oxigênios (Taylor, 1997).

\subsubsection{Aluminato tricálcico $\left(\mathrm{C}_{3} \mathrm{~A}\right)$}

Aluminato constitui 5-10\% em peso do clínquer da maior parte dos cimentos Portland. É aluminato tricálcico $\left(\mathrm{Ca}_{3} \mathrm{Al}_{2} \mathrm{O}_{6}\right)$, substancialmente modificado em composição e às vezes também em estrutura por substituições iônicas (Taylor, 1997). Este reage rapidamente com água, então atua no desenvolvimento de resistências iniciais. Além disso, pode causar o indesejável tempo de pega rápido, a menos que haja uma adição de um agente controlador de pega, geralmente, o gesso. $\mathrm{O}$ controle de pega origina a formação de uma capa protetora com aspecto de gel $\left(3 \mathrm{CaO} \cdot \mathrm{Al}_{2} \mathrm{O}_{3} \cdot 3 \mathrm{CaSO}_{4} \cdot 31 \mathrm{H}_{2} \mathrm{O}\right)$. Esta envolve as partículas do cimento reduzindo a hidratação, causando o retardamento do início de pega.

$\mathrm{O}$ aluminato compõe junto com o $\mathrm{C}_{4} \mathrm{AF}$, a chamada fase intersticial, preenchendo os espaços compreendidos entre os cristais de $\mathrm{C}_{3} \mathrm{~S}$ e $\mathrm{C}_{2} \mathrm{~S}$ e desempenham importante papel, como fase líquida, na formação e desenvolvimentos dos silicatos durante a clinquerização. Podem ocorrer bem diferenciados, isto é, cristalizados ou sob a forma de textura vítrea, onde se torna impossível a sua distinção (Shukuzawa, 1986). 
A presença dos óxidos de ferro e alumínio é fundamental como fundentes, facilitando as reações de clinquerização e reduzindo a temperatura de formação do clínquer o que conduz à uma economia de energia térmica do processo de clinquerização.

$\mathrm{O} \mathrm{C}_{3} \mathrm{~A}$ não apresenta polimorfismo. $\mathrm{O} \mathrm{C}_{3} \mathrm{~A}$ contém $62,3 \% \mathrm{CaO}$ e $37,7 \%$ $\mathrm{Al}_{2} \mathrm{O}_{3}$ em massa. Proporções substanciais de $\mathrm{Ca}$ e $\mathrm{Al}$ são então substituídos, o conteúdo total de óxidos substituintes sendo em torno de 13\% para o cúbico e acima de aproximadamente $20 \%$ para a modificação ortorrômbica. O conteúdo de $\mathrm{Na}_{2} \mathrm{O}$ equivalente $\left(\mathrm{Na}_{2} \mathrm{O}+0,66 \mathrm{~K}_{2} \mathrm{O}\right)$ aparece para estar em torno de $1 \%$ para a forma cúbica e 2-4\% para a forma ortorrômbica.

Vale destacar a estrutura cúbica formada por íons $\mathrm{Ca}^{+2}$ e anéis de tetraedros de $\mathrm{AlO}_{4}$, cuja fórmula pode ser expressa por $\mathrm{Al}_{6} \mathrm{O}_{18}{ }^{-18}$ (Mondal e Jeferry, 1975 apud Taylor, 1997-Vide Figura 26). Esta estrutura pode ser vista na Figura 26. A célula unitária é composta por 64 subcélulas. Dessas subcélulas, oito são ocupadas por $\mathrm{Al}_{6} \mathrm{O}_{18}{ }^{-18}$, os íons $\mathrm{Ca}^{+2}$ estão localizados nos centros do corpo de algumas das subcélulas remanescentes e próximos das arestas de outras subcélulas.

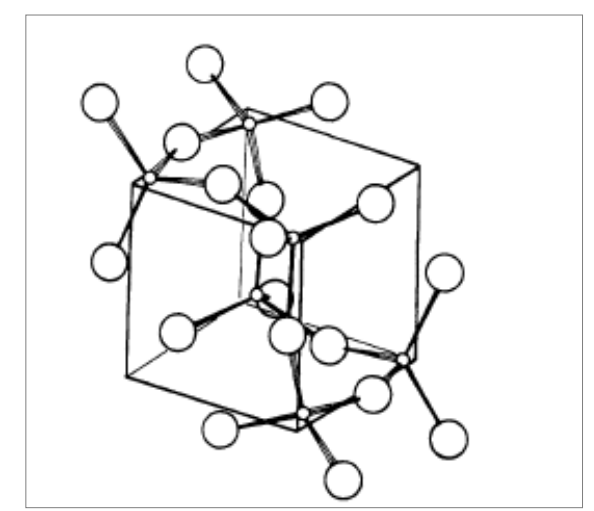

Figura 26 - Anel $\mathrm{Al}_{6} \mathrm{O}_{18}$ na estrutura $\mathrm{C}_{3} \mathrm{~A}$.

Fonte: Mondal e Jeferry,1975 apud Taylor, 1997

$\mathrm{O} \mathrm{C}_{3} \mathrm{~A}$ pode incorporar um íon $\mathrm{Na}^{+}$por substituição do íon $\mathrm{Ca}^{+2}$ com inclusão de um segundo íon $\mathrm{Na}^{+}$que está numa posição diferente de vacância, então fornece soluções sólidas de fórmula genérica $\mathrm{Na}_{2 \mathrm{x}} \mathrm{Ca}_{3-\mathrm{x}} \mathrm{Al}_{2} \mathrm{O}_{6}$. A substituição ocorre sem mudança na estrutura até o limite de $1 \%$ de $\mathrm{Na}_{2} \mathrm{O}$ (Taylor, 1997).

Proporções significativas de íons $\mathrm{Al}^{+3}$ podem ser substituídas por outros íons, principalmente por $\mathrm{Fe}^{+3}$ e $\mathrm{Si}^{+4}$ nessas estruturas (Taylor, 1997). Lee et al encontrou os limites de substituição dentro das condições de equilíbrio para estarem 
em aproximadamente $2 \%$ para a $\mathrm{SiO}_{2}$ e $3-4 \%$ para o $\mathrm{Fe}_{2} \mathrm{O}_{3}$. No caso de maiores teores de substituição, estes serão obtidos dentro de condições de não equilíbrio. A literatura contém muitas referências para um suposto composto $\mathrm{NC}_{8} \mathrm{~A}_{3}\left(\mathrm{~N}=\mathrm{Na}_{2} \mathrm{O}\right)$. Esta fórmula corresponde a um suposto conteúdo de $\mathrm{Na}_{2} \mathrm{O}$ de $7.6 \%$ que não poderá ser incorporado em $\mathrm{C}_{3} \mathrm{~A}$ substituindo somente com $\mathrm{Na}^{+}$. Entretanto, se Si estiver presente, o limite máximo de substituição de $\mathrm{Na}^{+}$é próximo a este valor.

Com relação à substituição significativa de $\mathrm{K}^{+}$, este pode estabilizar o clínquer juntamente com outros íons em condições de não equilíbrio. Maki conseguiu preparar a incorporação de $\mathrm{K}^{+}$pelo $\mathrm{C}_{3} \mathrm{~A}$ em resfriamento rápido moderado resultando em cristais ortorrômbicos. Ele considerou que a presença de Si na fase líquida do clínquer favorece as condições de super resfriamento e a formação de $\mathrm{C}_{3} \mathrm{~A}$ nas formas ortorrômbicas ou monoclínicas (Taylor, 1997).

\subsubsection{Ferroaluminato tetracálcico $\left(\mathrm{C}_{4} \mathrm{AF}\right)$}

A ferrita constitui 5-15\% em massa de clínqueres de cimento Portland normais. É ferroaluminato tetracálcico $\left(\mathrm{Ca}_{2} \mathrm{AlFeO}_{5}\right)$, substancialmente modificada em composição pela variação na razão $\mathrm{Al} / \mathrm{Fe}$ e de substituições iônicas. As velocidades com que reagem om água são ligeiramente variáveis, talvez devido a diferenças na composição ou outras características, mas em geral é alta inicialmente e baixa ou muito baixa em idades mais avançadas (Taylor,1997). É importante na resistência a corrosão química, além de ser o responsável pela coloração acinzentada do clínquer, dada a presença do ferro. Clínquer branco não contém $\mathrm{C}_{4} \mathrm{AF}$ (Centurione, 1990).

A fase ferrita faz parte da composição das séries de solução sólida $\mathrm{Ca}_{2}\left(\mathrm{Al}_{\mathrm{x}} \mathrm{Fe}_{1-\mathrm{x}}\right)_{2} \mathrm{O}_{5}$ onde $0<\mathrm{x}<0.7$. A composição $\mathrm{C}_{4} \mathrm{AF}$ é somente um ponto nestas séries com $\mathrm{x}=0.5$. $\mathrm{O}$ membro extremo $\mathrm{C}_{2} \mathrm{~A} \operatorname{com} \mathrm{x}=1$ só é viável a sua preparação a $2500 \mathrm{MPa}$. Enquanto que o outro extremo com $\mathrm{x}=0$ é representado por $\mathrm{Ca}_{2} \mathrm{Fe}_{2} \mathrm{O}_{5}$.

A estrutura cristalina aproximada de $\mathrm{C}_{4} \mathrm{AF}$ é ortorrômbica. Esta é caracterizada onde cada íon $\mathrm{Ca}^{+2} \mathrm{em} \mathrm{C}_{4} \mathrm{AF}$ tem 7(sete) vizinhos de oxigênio. Os átomos de alumínio e ferro são ambos distribuídos entre sites tetraédricos e octaédricos. A fração do alumínio em sites tetraédricos dentro de condições de equilíbrio decresce com a temperatura. Num experimento com valores de $\mathrm{x}$ da 
fórmula $\mathrm{Ca}_{2}\left(\mathrm{Al}_{\mathrm{x}} \mathrm{Fe}_{1-\mathrm{x}}\right)_{2} \mathrm{O}_{5}$ de 0,$285 ; 0,36$ e 0,5 em que as determinações de estrutura por Difração de Raios-X foram executadas, $75-76 \%$ do conteúdo total de alumínio foi encontrado em sites tetraédricos. Estas preparações foram mostradas por estarem em equilíbrio a $750^{\circ} \mathrm{C}$; para uma preparação de $\mathrm{C}_{4} \mathrm{AF}$ aquecida de $1290^{\circ} \mathrm{C}$, o espectro de Mossbauer indicou que somente 68\% do alumínio estava em sites tetraédricos.

A típica composição difere de forma significativa daquele de $\mathrm{C}_{4} \mathrm{AF}$ (46.1\% $\mathrm{CaO} ; 21,0 \% \mathrm{Al}_{2} \mathrm{O}_{3} ; 32,9 \% \mathrm{Fe}_{2} \mathrm{O}_{3}$ ). Este contém cerca de $10 \%$ de óxidos substitutos. Isto se aproxima de $\mathrm{Ca}_{2} \mathrm{AlFe}_{0.6} \mathrm{Mg}_{0.2} \mathrm{Si}_{0.15} \mathrm{Ti}_{0.05} \mathrm{O}_{5}$, que é derivado daquele de $\mathrm{C}_{4} \mathrm{AF}$ pela substituição de alguns dos íons $\mathrm{Fe}^{+3}$ pelo $\mathrm{Mg}^{+2}$ e uma quantidade igual por $\mathrm{Si}^{+4}$ e $\mathrm{Ti}^{+4}$.

\subsubsection{Cal livre, periclásio e os sulfatos alcalinos.}

A cal livre, o periclásio e os sulfatos alcalinos são considerados elementos secundários do clínquer Portland, porém, sua presença pode apresentar influências no comportamento reológico e desempenho do cimento.

A cal livre é um elemento residual do processo de fabricação, que se cristaliza a partir do $\mathrm{CaO}$ que não reagiu com a sílica ou alumínio para a formação dos componentes principais. A cal livre é normalmente encontrada em teores que variam de 0,5 a 2,0\% em peso, podendo atingir em alguns clínqueres industriais teores de até $6 \%$. Nesses casos, há possibilidades reais de que houve algum problema no processo. Em função disso, o teor de cal livre no clínquer tem sido utilizado como um importante parâmetro de avaliação da eficiência do processo de clinquerização (Kihara, 1990 apud Pecchio, 2013).

A forma cristalográfica da cal livre é arredondada com cor esbranquiçada, idiomórficos, separados, agrupados em zonas regulares ou irregulares ou como inclusões em aluminatos ou alita. As densidades dos cristais estão em torno de 3,32 $\mathrm{mg} / \mathrm{m}^{3}$. A microestrutura indica condições operacionais, tais como: dispersão dos grãos de cal livre (fator de saturação muito alto). Quanto à forma de cristais em zonas, esta indica finura da moagem e uniformidade do material cru. Portanto, seas zonas forem irregulares, indica uma homogeneização inadequada de grãos grossos de calcita no material cru (Campbell, 1999). 
Em teores elevados (acima de 3\% em peso), a cal livre influencia negativamente o desenvolvimento de resistência mecânica, aumenta o calor de hidratação e pode causar sérios problemas de expansibilidade, já que sua transformação em $\mathrm{Ca}(\mathrm{OH})_{2}$ é acompanhada por um aumento de volume de mais de 95\% (Pechio, 2013).

O periclásio é o $\mathrm{MgO}$ livre cuja decorrência é da utilização de calcários dolomíticos com teores acima de 1,5 a 2\% de $\mathrm{MgO}$ em suas composições (Kihara,1990). Este é encontrado no estado cristalizado, resultante do resfriamento lento do clínquer. Esta sofre hidratação lenta, formando a brucita $\operatorname{Mg}(\mathrm{OH})_{2}$ causadora de expansão do cimento endurecido. As formas dos cristais podem ser idiomórficos (retangular ou octaédrico) ou xenomórficos (irregulares ou dendríticos conforme condições de resfriamento (Campbell, 1999). Os idiomórficos indicam condições de resfriamento lento enquanto os subdiomórficos e irregulares, condições mais rápidas de resfriamento. Os cristais são pequenos, variando de $1 \mathrm{a}$ $10 \mu \mathrm{m}$, de cor rosa e apresentam uma densidade de $3,58 \mathrm{mg} / \mathrm{m}^{3}$.

O modo de ocorrência dos cristais: dispersos ou agrupados em zonas dependem fundamentalmente das condições de moagem das matérias-primas (Kihara,1990). As zonas de periclásio associados à cal livre indicam grãos grosseiros oriundo de uma moagem inadequada e quanto os cristais individuais e dispersos indicam moagem adequada (Campbell,1999).

O periclásio juntamente com a cal livre são os principais responsáveis pelos fenômenos de expansão dos cimentos. Difere da cal livre pela velocidade mais lenta e caráter mais expansivo da reação (118\% para periclásio) (Kihara,1990). Entretanto, de acordo com o estudo de Kihara, os valores de correlação entre os teores de $\mathrm{MgO}$ e os valores de expansão em cura normal (10 anos) ou em autoclave são baixos e que a expansão é fortemente influenciada pelo cal livre. Nas normas brasileiras, o limite máximo de $\mathrm{MgO}$ é de 6,5\% e os valores são semelhantes no resto do mundo.

Os sulfatos alcalinos presentes no clínquer devido a incorporação do enxofre e álcalis provenientes da matéria-prima e combustível sólido. O enxofre, especificamente, é derivado do coque que contém 4 a $6 \%$ deste conforme item 2.1.4.

Os sulfatos de sódio e potássio estão presentes em percentuais baixos no clínquer, mas tem efeitos importantes que ocorrem nas primeiras ações de hidratação devido a solubilidade muito alta destas fases. Quanto à visualização no 
microscópico de luz transmitida, variedades de sulfato alcalino são difíceis de distinguir, ocorrendo em muitos casos nas formas transparentes, irregulares e em estruturas multifásicas de cristais de intercrescimento que somente podem ser visualizados em seções muito finas (Campbell,2004).

O excesso desses materiais acarreta pertubações consideráveis no sistema do forno rotativo quando ocorre a circulação dos voláteis. O pó que não é absorvido pelo clínquer é arrastado de volta com os gases quentes para as áreas mais frias do sistema. Estes ciclos de voláteis são reorganizados no pré-aquecedor e podem formar depósitos sólidos ou semi-sólidos. Estes depósitos podem restringir o movimento do material e dos gases. Dentro do forno, eles formam anéis de colagem (Taylor, 1997). Como exemplos de sulfatos alcalinos, pode-se destacar: arcanita $\left(\mathrm{K}_{2} \mathrm{SO}_{4}\right)$, cálcio langbeinita $\left(\mathrm{K}_{2} \mathrm{SO}_{4} \cdot 2 \mathrm{CaSO}_{4}\right)$ e aphthitalita $\left[\left(\mathrm{K}_{2} \mathrm{Na}\right)_{2} \mathrm{SO}_{4}\right]$.

\subsection{Influência dos elementos menores no clínquer}

De acordo com Rompps Chemie-Lexicon (1987 apud Bhatty, 1995) classifica elementos maiores com concentrações acima de 5\% em peso que é o caso de $\mathrm{Ca}, \mathrm{Si}, \mathrm{Al}, \mathrm{Fe}, \mathrm{O}, \mathrm{C}$ e N. Enquanto que os elementos secundários e menores estão presentes em 1-5\% e abaixo de 1\% no clínquer (Miller,1976 \& Gartner, 1980 apud Bhatty, 1995), respectivamente. $\mathrm{E}$, finalmente, os traços de elementos estão presentes no teor abaixo de 0,02\% (Blaine et al, 1965 apud Bhatty, 1995).

A Tabela 10 apresenta concentrações médias de elementos menores e traços no clínquer (Moir e Glasser (1992) apud Pecchio, 2013). 
Tabela 10-Concentração média de elementos menores e traços encontrados no clínquer (Moir e Glasser, 1992 apud Pechio, 2013)

\begin{tabular}{cc}
\hline Elementos menores & Concentração (ppm) \\
\hline $\mathrm{Mg}$ & 8900 \\
\hline $\mathrm{K}$ & 6100 \\
$\mathrm{~S}$ & 3200 \\
\hline $\mathrm{Na}$ & 1200 \\
\hline $\mathrm{Ti}$ & 1600 \\
\hline $\mathrm{Mn}$ & 420 \\
\hline $\mathrm{P}$ & 440 \\
\hline $\mathrm{Sr}$ & 590 \\
\hline $\mathrm{Zn}$ & 96 \\
\hline $\mathrm{Cr}$ & 70 \\
\hline $\mathrm{V}$ & 56 \\
\hline $\mathrm{Cl}$ & 90 \\
\hline $\mathrm{As}$ & 42 \\
\hline $\mathrm{Cu}$ & 44 \\
\hline $\mathrm{Pb}$ & 15 \\
\hline $\mathrm{Cd}$ & 0,5 \\
\hline $\mathrm{Tl}$ & 0,3
\end{tabular}

As fontes de elementos menores são provenientes da matéria-prima e combustíveis e de forma significativa pelos corretivos de módulos químicos. A Tabela 11 apresenta os teores médios de elementos menores presentes em calcários e argilas utilizados como matéria-prima [Sprung(1985); Weisweiler e Kromar(1989) apud Bhatty, 1995] 
Tabela 11-Concentração média de elementos menores em calcários e argilas

(Fonte: Sprung, 1985 apud Bhatty, 1995)

\begin{tabular}{ccc}
\hline Elementos menores & Calcário $(\mathbf{p p m})$ & Argila $(\mathbf{p p m})$ \\
\hline $\mathrm{As}$ & $0,2-12$ & $13-23$ \\
\hline $\mathrm{Be}$ & 0,5 & 3 \\
$\mathrm{Cd}$ & $0,035-0,1$ & $0,016-0,3$ \\
\hline $\mathrm{Cr}$ & $1,2-1,6$ & $90-109$ \\
$\mathrm{~Pb}$ & $0,4-13$ & $13-22$ \\
\hline $\mathrm{Hg}$ & 0,03 & 0,45 \\
\hline $\mathrm{Ni}$ & $1,5-7,5$ & $67-71$ \\
\hline $\mathrm{Se}$ & 0,19 & 0,5 \\
\hline $\mathrm{Ag}$ & $n . a \cdot *$ & 0,07 \\
\hline $\mathrm{Tl}$ & $0,05-0,5$ & $0,7-1,6$ \\
\hline $\mathrm{V}$ & $10-80$ & $98-170$ \\
\hline $\mathrm{Zn}$ & $22-24$ & $59-115$ \\
\hline $\mathrm{Cl}$ & $50-240$ & $15-450$ \\
\hline $\mathrm{F}$ & $100-940$ & $300-990$ \\
\hline $\mathrm{Br}$ & 5,9 & $1-58$ \\
\hline $\mathrm{I}$ & $0,25-0,75$ & $0,2-2,2$ \\
\hline
\end{tabular}

Já os resíduos são a segunda fonte desses elementos, mas importantes que podem substituir parcial ou totalmente o combustível primário.

No Brasil, conforme item 2.1.4, os combustíveis, na sua matriz energética, têm uma predominância do coque verde de petróleo que aporta quantidades significativas de enxofre, vanádio e níquel. A Tabela 12 exibe concentração média de elementos menores e traços em combustíveis. 
Tabela 12 - Concentração média de elementos menores e traços em combustíveis Fonte: Sprung, 1985 and Weisweiller and Kromar, 1989 apud Bhatty, 1995.

Elementos menores Carvão Óleos usados Coque de petroleo (ppm)

\begin{tabular}{|c|c|c|c|}
\hline $\mathrm{Sb}$ & 1,19 & n.d. ${ }^{*}$ & 0,043 \\
\hline As & $9-50$ & $<0,01-100$ & 0,6 \\
\hline $\mathrm{Ba}$ & 24,5 & $0-3.906$ & 8,4 \\
\hline $\mathrm{Be}$ & 2,27 & n.d. & n.d. \\
\hline $\mathrm{Cd}$ & $0,1-10$ & 4 & n.d. \\
\hline $\mathrm{Cr}$ & $5-80$ & $<5-50$ & 11,0 \\
\hline $\mathrm{Pb}$ & $11-270$ & $<10-21.700$ & 8,7 \\
\hline $\mathrm{Hg}$ & 0,24 & n.d. & n.d. \\
\hline $\mathrm{Ni}$ & $20-80$ & $3-30$ & 208,0 \\
\hline $\mathrm{Se}$ & 3,56 & n.d. & 0,1 \\
\hline $\mathrm{Ag}$ & 0,06 & n.d. & n.d. \\
\hline $\mathrm{Tl}$ & $0,2-4$ & $<0,02$ & 0,1 \\
\hline $\mathrm{V}$ & $30-50$ & n.d. & 778,0 \\
\hline $\mathrm{Zn}$ & $16-220$ & $240-3.000$ & n.d. \\
\hline $\mathrm{Sr}$ & n.d. & n.d. & 4,3 \\
\hline $\mathrm{Cl}$ & $100-2.800$ & $10-2.200$ & n.d. \\
\hline $\mathrm{F}$ & $50-370$ & n.d. & n.d. \\
\hline $\mathrm{Br}$ & $7-11$ & n.d. & n.d. \\
\hline I & $0,8-11,2$ & n.d. & n.d. \\
\hline
\end{tabular}

A presença dos elementos menores pode ter os seguintes efeitos:

- Redução da temperatura da formação da fase líquida;

- Alterações na viscosidade e tensão superficial da fase líquida;

- Mudança na atividade hidráulica dos minerais do clínquer;

- Estabilização termodinâmica e composição das fases cristalinas;

- Modificação da morfologia dos cristais.

Ao longo do processo de clinquerização, as reações de estado sólido e cal livre encontram-se na fase intersticial ou líquida para geração da nucleação e crescimento da alita. A cinética dessas reações depende de propriedades tais como 
quantidade da fase líquida, viscosidade, tensão superficial e mobilidade iônica da fase.

O papel da fase líquida nas reações de clinquerização é aumentar a condutividade iônica, funcionando como "ponte" para os íons na formação ou decomposição de cristais (Christensen \& Johansen, 1979 apud Centurione, 1999).

As substâncias que têm a capacidade de aumentar a taxa de formação do clínquer são os chamados fundentes ou mineralizantes. Os fundentes reduzem a temperatura de formação da fase líquida e elevam o conteúdo total de fase. A ação desses fundentes é na aceleração das reações no estado sólido (descarbonatação de $\left.\mathrm{CaCO}_{3}\right)$ o que favorece o aumento do conteúdo da fase líquida. Quanto aos mineralizantes, estes favorecem as reações dentro do estado líquido ou na interface sólido-líquido, sem alterar a temperatura de formação e a quantidade da fase líquida (Singhet al.,1997 apud Centurione, 1999). Pode-se citar como exemplos de mineralizantes: $\mathrm{F}^{-}, \mathrm{SO}_{3}, \mathrm{Na}_{2} \mathrm{O}, \mathrm{BaO}$ e $\mathrm{Cl}^{-}$.

As propriedades de tensão superficial e viscosidade são alteradas na presença de fundentes ou mineralizantes. Em geral, a taxa de clinquerização é acelerada com a redução da viscosidade e aumento da tensão superficial (Osokin, 1986 in Singh et al, 1997 apud Centurione, 1999). A viscosidade influi na taxa de dissolução do $\mathrm{CaO}$ e do $\mathrm{C}_{2} \mathrm{~S}$ na fase líquida além da difusão dos íons $\mathrm{Ca}^{+2}, \mathrm{O}^{-2}$, $\mathrm{SiO}_{4}^{-4}$, que favorecem a formação do $\mathrm{C}_{3} \mathrm{~S}$. Já a tensão superficial influencia as reações do estado sólido especificamente para controlar a penetração do líquido nos poros das partículas de $\mathrm{CaO}$ resultantes da reação de descarbonatação do $\mathrm{CaCO}_{3}$.

A atividade hidráulica do clínquer é influenciada fundamentalmente pelos seguintes processos: introdução de defeitos ou tensões no retículo cristalino dos principais constituintes do clínquer, estabilização à temperatura ambiente de polimorfos de alta temperatura mais reativos e desenvolvimento de reações durante o processo de hidratação.

Estudos (Timashev, 1980 et al Moir \& Glasser, 1992 apud Centurione, 1999) foram realizados para demonstrar a influência dos componentes menores na viscosidade e tensão superficial. Os resultados estão citados abaixo:

- Elementos fortemente eletropositivos e eletronegativos- Elementos fortemente eletropositivos como $\mathrm{K}^{+}$e $\mathrm{Na}^{+}$aumentam a viscosidade da 
fase líquida enquanto que os fortemente eletronegativos como $\mathrm{Cl}^{-}$e $\mathrm{F}^{-}$ reduzem-na.

- Elementos da camada s e p - A tensão superficial cresce com o aumento da eletronegatividade dos elementos da camada "s" (alcalinos e alcalinos terrosos), mas decrescem com o aumento da eletronegatividade dos elementos da camada "p" (flúor, alumínio, silício, cloro, por exemplo).

- Metais de transição - Verifica-se que a viscosidade e tensão superficial são reduzidas à medida que o estado de oxidação dos elementos aumenta (na ordem $\mathrm{Cd}^{+2}>\mathrm{Zn}>\mathrm{Ni}>\mathrm{Cu}>\mathrm{Co}>\mathrm{Fe}>\mathrm{Mn}$ $>\mathrm{Ti}>\mathrm{Cr}>\mathrm{V}>\mathrm{W}>\mathrm{Mo}^{+6}$ ) que corresponde também ao enfraquecimento de suas propriedades ácidas e fortalecimento da ligação metal-oxigênio.

Vale mencionar que os metais de transição têm um efeito marcante no processo de sinterização, na estrutura cristalina e textura dos minerais do clínquer e nas reações de hidratação (Kakali et al., 1998 apud Maringolo, 2001). Esta forte característica é devido a múltiplos estados de oxidação, dimensões pequenas e formação de íons de cargas elevadas.

\subsection{Fundamentos de PCA}

\subsubsection{Definição}

O PCA é uma técnica multivariada que busca reduzir a dimensionalidade de variáveis com a formação de uma outra base para que seja possível visualizá-los num subespaço próximo de duas dimensões. A ideia é transformar a base de dados experimentais com variáveis inter-relacionados em uma nova série com menos variáveis não correlacionadas chamadas componentes principais. Estes são ordenados de tal forma que as primeiras variáveis desta nova base manterão a maior parte da variabilidade presente de todas as variáveis originais. 
A vantagem desta ferramenta é a possibilidade de analisar tendência, padrões, outliers num espaço reduzido, fazer a interpretação de forma prática e definir as variáveis mais importantes de um sistema experimental. A figura 27 abaixo mostra o gráfico de PCA.

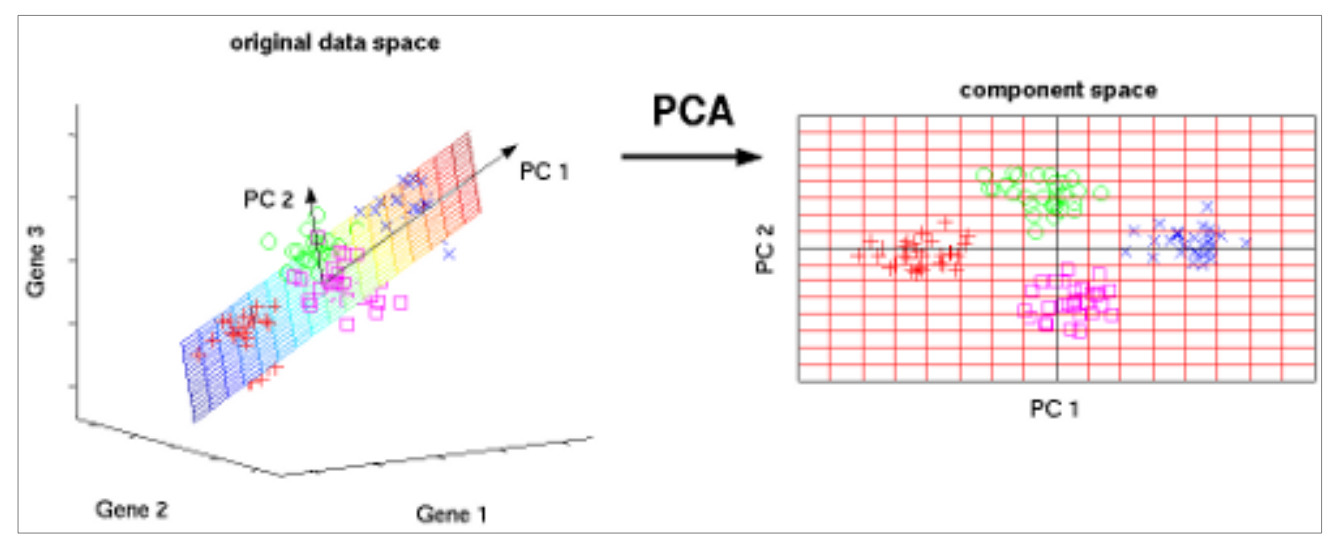

Figura 27- Gráfico PCA

Fonte: Matthias Scholz, Ph.D.thesis

A transformação da base de dados envolve fundamentos de álgebra linear. Imagine uma matriz $X$, dimensão $\mathbf{m} \mathbf{x} \mathbf{1}$, onde as linhas $\mathbf{m}$ são as amostras (observações). O objetivo é a partir da matriz $\boldsymbol{X}$, obter a matriz $\boldsymbol{Z}$ de dimensão $\mathbf{m} \mathbf{x}$ $\mathbf{n}$, por meio da matriz $\boldsymbol{A}$, de dimensão $1 \mathbf{x} \mathbf{n}$.

$$
Z=A X \text { (eq. } 1)
$$

Esta equação representa uma mudança de base. Multiplicando as colunas de A que são os vetores de coluna $\mathrm{a}_{1}, \mathrm{a}_{2}, \ldots \mathrm{a}_{\mathrm{n}}$, e as linhas de $\boldsymbol{X}$ que são os vetores de linha $\mathrm{x}_{1}, \mathrm{x}_{2}, \ldots \mathrm{x}_{\mathrm{m}}$, então temos um espaço vetorial real de dimensão finita expresso pelo produto interno desses vetores, cujo resultado $\boldsymbol{Z}$ é uma nova base de dados por meio da projeção de $\boldsymbol{X}$ sobre $\boldsymbol{A}$. A matriz $\boldsymbol{A}$ faz a rotação durante a transformação de $\boldsymbol{X}$ para $\boldsymbol{Z}$. As colunas de $\boldsymbol{A}$ são uma nova base de vetores para expressar as linhas de $\boldsymbol{X}$.

A preservação da variabilidade com mesmas variâncias, ou covariâncias, e correlações nas primeiras variáveis num espaço reduzido pelos componentes principais em relação aos dados originais pode ser expressa na seguinte função linear:

$$
\left.\alpha_{1}^{\prime} x=\alpha_{11} x_{1}+\alpha_{12} x_{2}+\cdots+\alpha_{1 p} x_{p}=\sum \alpha_{1 j} x_{j} \text { (eq. } 2\right)
$$


onde $\mathbf{x}$ é um vetor de variáveis aleatórias, sendo que os elementos de $\mathbf{x}$ têm máxima variância onde $\alpha_{1}$ é um vetor de constantes $\mathbf{p} \alpha_{11}, \alpha_{12, \ldots, \alpha_{1 p}}$ e 'significa transposta. É o primeiro componente principal. Tomando a outra função linear $\alpha_{2}{ }^{\prime} \mathrm{x}$ que é independente de $\alpha_{1}^{\prime}$ x com o segundo valor de variância, é o segundo componente principal, e assim por diante até a $\alpha_{\mathrm{k}}{ }^{\prime} \mathrm{x}, \mathrm{o} \mathrm{k}^{\text {th }}$ componente principal. Além disso, sabe-se que num total de p PCs, existem m PCs que contemplam a maior parte da variação de $\mathrm{x}$ onde $\mathbf{m}<<\mathbf{p}$.

A não-correlação ou independência linear entre as variáveis desta nova base está relacionado justamente com a preservação da variância da base de dados original. Os vetores vão direcionar ao valor de máxima variância. Esta independência será melhor explicada no cálculo para obtenção da matriz de covariância e pré-requisitos para sua construção (item 2.5.2.2).

\subsubsection{Conceitos "Score" e "Loading"}

Sejam as combinações lineares PC1 e PC2 citados abaixo:

$\mathrm{PC} 1=\alpha_{1} \mathrm{X}_{1}+\alpha_{2} \mathrm{X}_{2}$ e PC2 $=\beta_{1} \mathrm{X}_{1}+\beta_{2} \mathrm{X}_{2}($ eq.3)

Onde:

PC1 e PC2 = scores ou dados originais transformados na nova base

$\mathrm{X}_{1}$ e $\mathrm{X}_{2}=$ dados originais

$\alpha_{1}$ e $\alpha_{2}=$ loadings ou coeficientes dos dados originais que geram os scores.

\subsubsection{Sistemática de processamento de dados}

\subsubsection{Tratamento prévio de dados}

Antes de dar início aos cálculos para encontrar os PCs, é necessário normalizar o banco de dados original, devido as diferenças de escala destes que podem interferir nos resultados. Para isso, é necessário tomar cada dado e subtrair pela média e dividir pelo desvio padrão desses dados conforme relação abaixo: 


$$
X^{*}=\frac{X-\mu}{\sigma}(e q .4)
$$

Para checar se a normalização foi bem realizada, basta observar se a média e o desvio padrão são iguais a zero e um, respectivamente.

\subsubsection{Cálculo da Matriz de Covariância}

Seja a matriz de dados $\boldsymbol{X}$ com $\mathbf{m}$-linhas e $\mathbf{n}$-colunas, a matriz de covariância S é:

$$
S=\operatorname{cov}(X)=\left(\frac{1}{m-1}\right) * X^{\prime} X(e q .5)
$$

No caso de $\mathbf{n}$ dimensões de uma série de dados, haverá $\frac{n !}{2(n-2) !}$ valores de covariância. Como exemplo da matriz de covariância S, cita-se uma série de dados de três dimensões $(\mathrm{x}, \mathrm{y}, \mathrm{z})$ :

$$
\begin{array}{rll}
\operatorname{cov}(x, x) & \operatorname{cov}(x, y) & \operatorname{cov}(x, z) \\
S=\operatorname{cov}(y, x) & \operatorname{cov}(y, y) & \operatorname{cov}(y, z)(\text { eq. } 6) \\
\operatorname{cov}(z, x) & \operatorname{cov}(z, y) & \operatorname{cov}(z, z)
\end{array}
$$

Observa-se que foram calculadas todas as possíveis pares de covariâncias entre as três variáveis. Na diagonal principal, tem-se as variâncias e nos elementos exteriores à aquela diagonal, obtém-se as covariâncias. Portanto, essa matriz é conhecida como Matriz de Covariância.

O pressuposto fundamental do método PCA é que a não-correlação destas diferentes variáveis são próximas ou iguais a zero. Portanto, pode-se concluir que $\mathrm{S}$ é uma matriz diagonal (simetria devido a $\operatorname{cov}(\mathrm{a}, \mathrm{b})=\operatorname{cov}(\mathrm{b}, \mathrm{a})$ ) Além disso, é importante mencionar que são necessários os seguintes requisitos para construção da matriz de covariância $\mathbf{S}$ :

-Maximização do sinal medido pela variância (diagonal principal)

-Minimização da covariância entre variáveis (elementos exteriores à diagonal principal). 


\subsubsection{Cálculo dos autovalores e autovetores da matriz de covariância}

Os autovalores e autovetores de uma matriz $S$ que são o escalar $\lambda$ e o vetor $\mathrm{V}$ que atendem a seguinte equação:

$$
\mathrm{SV}-\lambda \mathrm{V}=0 \text { onde } \mathrm{V}>0 \text { (eq.7) }
$$

Onde $\boldsymbol{\lambda}$ é o autovalor correspondente ao autovetor $\boldsymbol{V}$ e $\boldsymbol{S}$ a matriz de covariância. Outra forma de visualizar esse cálculo dos autovalores e autovetores é diagonalizar a matriz de covariância $S$ pelo método da decomposição de valor singular (SVD): Suponha que a matriz $\boldsymbol{P}\left(\mathrm{p}_{1}, \mathrm{p}_{2}, \ldots \mathrm{p}_{\mathrm{m}}\right)$ seja ortogonal. Considerando a relação da matriz de covariância $S$ e sabendo que Y está em função de X e Y, substitui-se o Y na matriz de covariância supracitada. Um fundamento de álgebra linear diz que a matriz simétrica $\sum$ de tamanho $\mathbf{m}$ é $\sum=\mathbf{X X}^{\mathbf{T}}$ (Demonstração em Richardson, 2009). Portanto, temos:

$$
\sum=B P B^{T}(\text { eq. } 8)
$$

Onde:

$\boldsymbol{B}=$ matriz $\mathrm{B}$ ortonormal $\mathrm{m} \times \mathrm{m}=$ as colunas são os autovetores ortonormais de $\sum$ (direção das máximas variâncias).

$\boldsymbol{P}=$ matriz diagonal $=$ a diagonal principal são os autovalores de $\sum$ (máximas variâncias naquela direção)

$B^{T}=$ matriz transposta de B.

Neste método de diagonalização da matriz de covariância é possível obter os autovetores e seus respectivos autovalores e também organizar os autovalores em ordem decrescente, especificamente na diagonal de D. Isto está coerente por meio da função linear mencionada anteriormente (item 2.5.1) com o primeiro componente principal ter a máxima variância, o segundo componente com segunda maior variância e assim por diante.

\subsubsection{Cálculo das matrizes "scores" e "loadings"}

A matriz de "scores" é definida da seguinte forma: 


$$
[X]\left(\left[P^{T}\right]\right)^{-1}=[T](e q .9)
$$

Onde:

$\left[X_{n x m}\right]=$ matriz de observações (matriz de dados originais normalizados)

$[P \mid m \times m]=$ matriz quadrada de autovetores ou matriz de loading .

$\left[T_{n x m}\right]=$ matriz de scores definido nos componentes principais

\subsubsection{Interpretação dos resultados do PCA}

As informações fornecidas pelos gráficos das matrizes de score e loading descrevem a relação entre as observações (amostras) e entre variáveis, respectivamente no sistema. A análise dos dois gráficos juntos é possível identificar as relações entre amostras e variáveis.

Como exemplo, os gráficos (Figuras 28 e 29) abaixo tratam de 4 observações (amostras) e 17 variáveis. O caso a ser avaliado é mostrar a média de consumo em gramas (por pessoa, por semana) de 17 diferentes tipos de alimentos em 4 países.

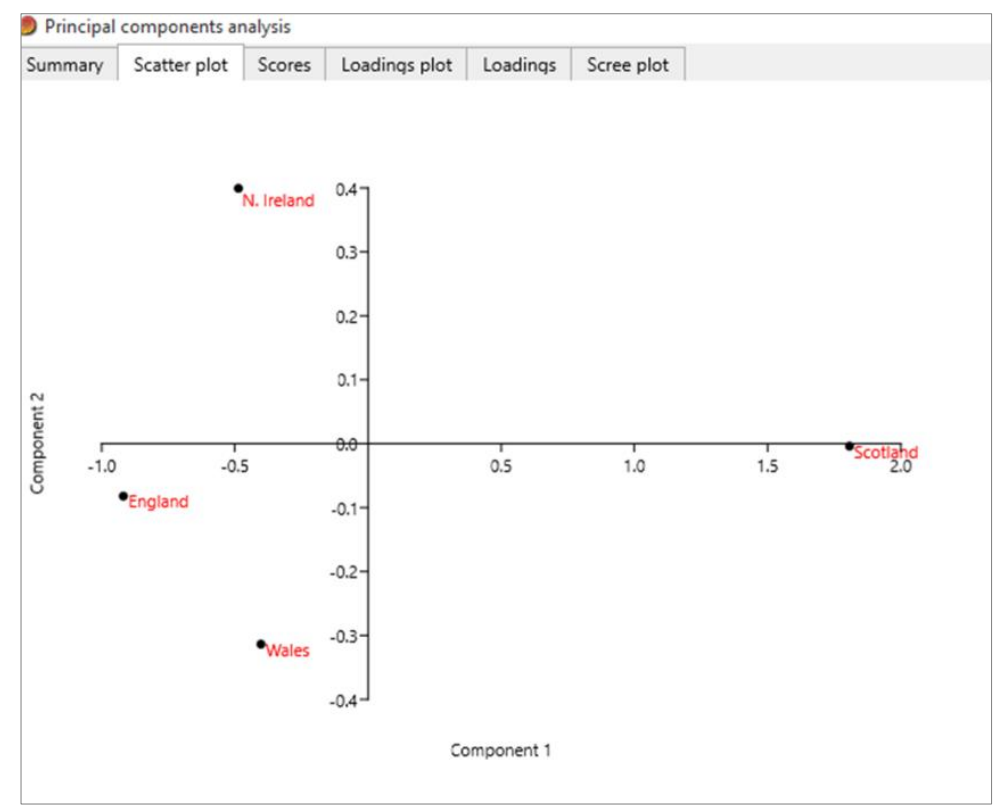

Figura 28-Gráfico de score

Fonte: Dados de Richardson, 2009 e gráfico feito no Past 3.25 pela autora

Na Figura 28 acima há uma demonstração de comportamento similar entre os países da Inglaterra, Irlanda do Norte e País de Gales formando um aglomerado 
enquanto que a Escócia está afastada deste aglomerado, isto é, tem um comportamento diferente.

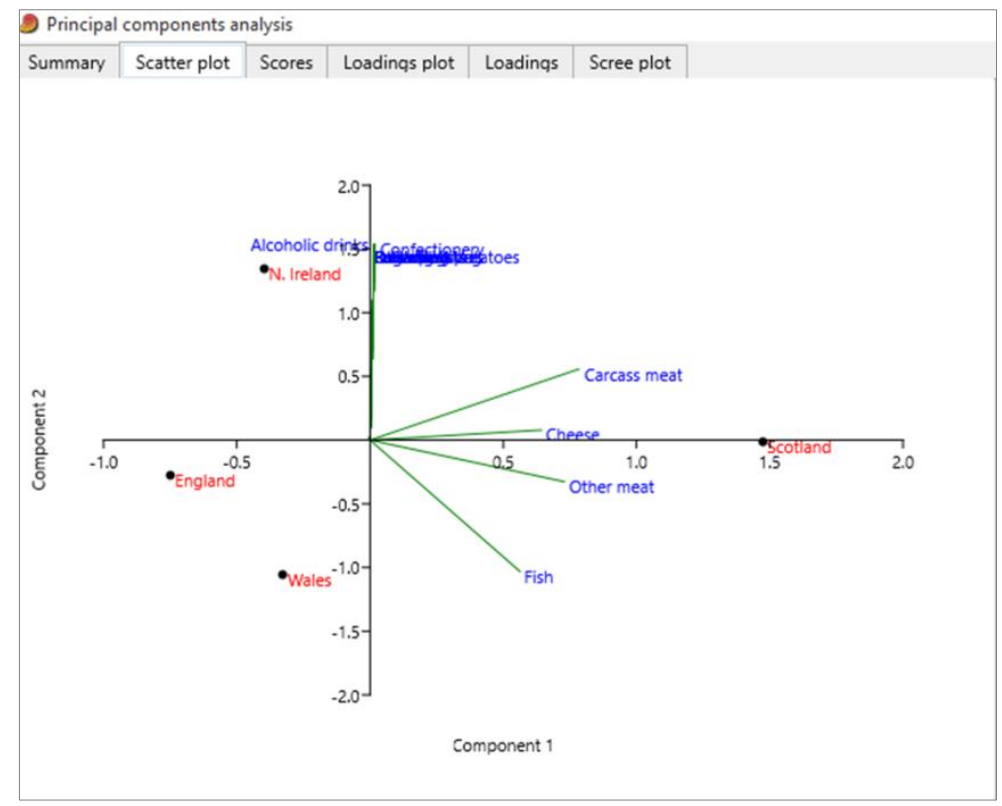

Figura 29-Gráfico de loading com score

Fonte: Dados de Richardson, 2009 e gráfico feito no Past 3.25 pela autora

Quanto à Figura 29 acima, é possível observar um aglomerado de variáveis na posição superior , ou seja, há uma indicação de uma forte correlação entre estas. Já as variáveis: "Carcass meat", "Cheese", "Other meat" e "Fish" prenunciam uma correlação mais fraca em relação ao primeiro grupo.

Derivada do método de análise de componentes principais, uma representação gráfica que exibe simultaneamente as n observações e p variáveis no mesmo espaço em duas dimensões é denominado de biplot. Este dispensa a necessidade de análise de vários gráficos em duas dimensões, isto é, torna a avaliação direta e bastante aproximada a uma série de dados original mais ampla. Além disso, o biplot fornece informação também sobre as relações entre as observações e variáveis. Ainda é possível analisar em três dimensões com auxílio de gráficos de computação interativa. Quanto maior o número de dimensões, mais difícil observar o gráfico de maneira mais clara e consequentemente interpretá-lo.

Existem variações de biplots, mas será analisado o biplot clássico desenvolvido por Gabriel (1971 apud Jolliffe, 2002). Estes são baseados na mesma teoria mencionada no item 2.5.2.3 - Decomposição do Valor Singular (SVD). 
Considera-se uma matriz $\boldsymbol{X}(\mathbf{n x p})$ de $\mathbf{n}$ observações em $\mathbf{p}$ variáveis medidos sobre as médias das amostras que são escritas desta forma:

$$
X=U L A^{T} \quad \text { (eq. 10) }
$$

Onde $\boldsymbol{U}$ (nxr), $\boldsymbol{A}$ (pxr) são matrizes ortonormais, respectivamente e $\boldsymbol{L}$ é uma matriz diagonal (rxr). De acordo com a demonstração que pode ser vista em Jolliffe (2002), a matriz $\boldsymbol{X}$ pode ser definida como:

$$
x_{i j}=\sum_{k=1}^{r} u_{i k} l_{k}^{1 / 2} a_{j k}
$$

Esta relação pode ser igualada a $x_{i j}=g_{i}^{\prime} h_{j}$ onde $\mathrm{g}$ e $\mathrm{h}$ correspondem as linhas de G e H (Demonstrado em Jolliffe, 2002). Escolhendo um subespaço de $\mathrm{m}$ dentro de r, temos:

$$
m x_{i j}^{\tilde{i}}=\sum_{k=1}^{m} g_{i k} h_{j k}=g_{i}^{*^{\prime}} h_{j}^{*} \text { (eq. 12) }
$$

Os $g_{i}{ }^{*} e h_{j}{ }^{*}$ equivalem aos primeiros m elementos de $g_{i}$ e $h_{i}$. Escolhendo $\mathrm{m}=2$, o $\mathrm{x}_{\mathrm{ij}} \tilde{\mathrm{C}}^{2}$ é uma boa aproximação de $\mathrm{x}_{\mathrm{ij}}$, $\mathrm{g}^{{ }^{* \prime}}$ e $\mathrm{h}_{\mathrm{j}}{ }^{*}$ juntos fornecem uma representação gráfica adequada em duas dimensões das n observações e p variáveis.

De acordo com a fatorização da forma (12), utilizando o escalar $\alpha=0$ (Vide demonstração em Jolliffe, 2002), temos HH'. Então os comprimentos $h_{j}^{\prime} h_{j} d o s$ vetores são proporcionais às variâncias das variáveis $\mathrm{x}_{1}, \mathrm{x}_{2}, \ldots \mathrm{X}_{\mathrm{p}}$ e os cosenos dos ângulos entre esses $h_{j}$ correspondem às correlações entre variáveis.

O exemplo de biplot (Vide Figura 30-Jolliffe,2002) abaixo demonstra uma série de dados com 54 pintores (observações) e 4 características (variáveis) com objetivo de analisar as qualidades artísticas de pintores. Os pontos representam os pintores e vetores, as características cujas denominações são composição (V1), desenho (V2), cor (V3) e expressão (V4). É possível observar que composição (V1) e expressão (V4) tem correlação relativamente forte positiva. Já desenho (V2) e cor (V3) estão em quadrantes opostos e têm forte correlação negativa.

Quanto às posições simultâneas dos pintores e variáveis, é possível observar a proximidade dos pintores 9 e 15 localizados abaixo do eixo positivo de x com a direção definida por V4, portanto nesta direção estes pintores têm pontuações altas. Já os pintores 16 e 19, estes têm a mesma posição localizados no fundo do quadrante do lado esquerdo. A direção V3 indica valores altos de pontuação para estes pintores supracitados. 


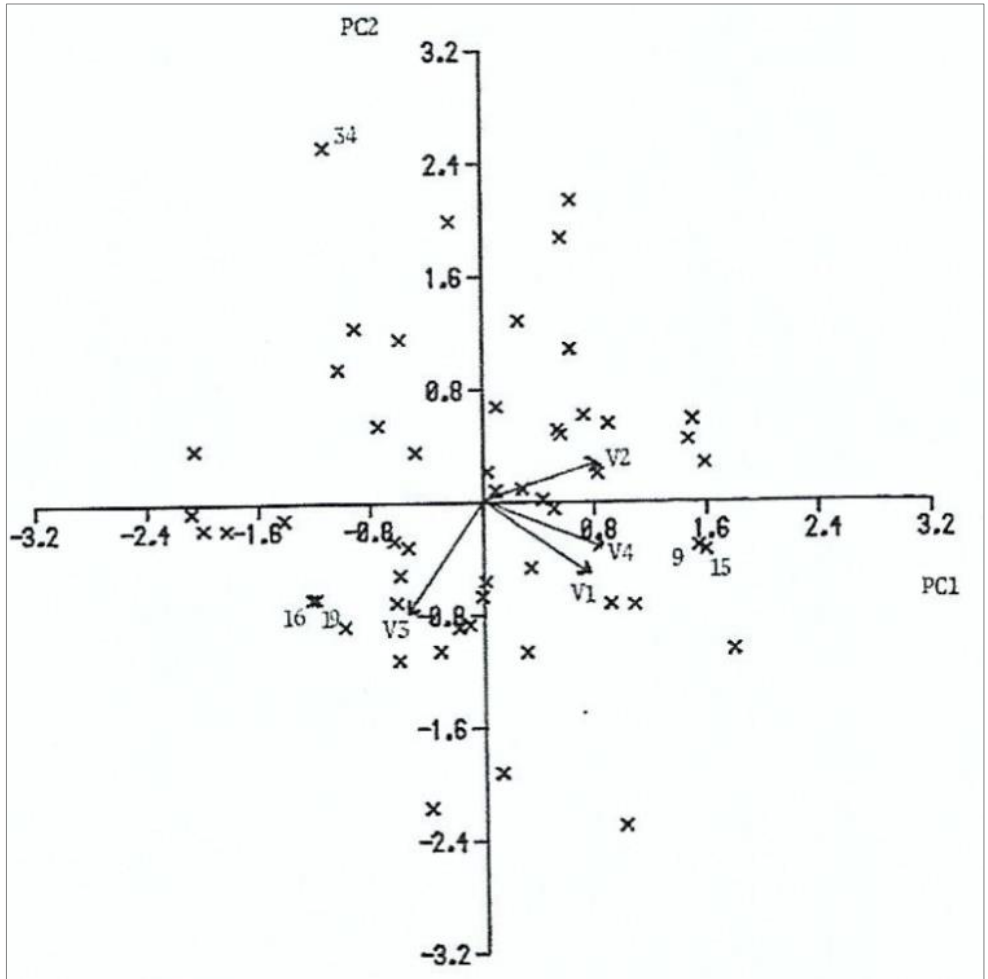

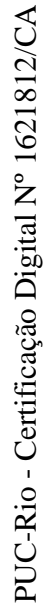

Figura 30-Biplot de qualidades artísticas de pintores

Fonte:Jolliffe,2002 


\section{3 \\ Metodologia Experimental}

No intuito de aproximação das condições reais de operação, foram utilizados os insumos/produtos: farinha, pó de retorno, clínquer e cimento cedidos pela Votorantim Cantagalo.

\subsection{Amostragem}

Foram coletadas amostras de farinha, pó de retorno e clínquer nos seguintes pontos respectivamente: entrada da Torre Intercambinadora, saída do filtro de mangas e transportador de clínquer do Resfriador de Grelhas do Sistema do Forno 2. A coleta foi realizada simultaneamente baseada no tempo de residência de cerca de 40 minutos do forno. O tempo total de coleta foi de 200 minutos. Após esta coleta, foi executada a amostragem média da farinha, pó de retorno e clínquer para análise química no Espectrômetro de Fluorescência de Raios X.

Quanto ao cimento, após operação estável do Moinho de Cimento 2, foi utilizado este clínquer e feita mistura com gesso e calcário. A mistura de cimento formada foi um CPI-S conforme norma ( $80 \%$ calcário, $10 \%$ calcário e $10 \%$ gesso). No intuito de alcance de resultados adequados de tempo de pega e resistência a compressão do cimento, foram verificadas através de ensaios rotineiros a finura e a superfície específica (conhecida como blaine) do cimento. Após essa checagem, foi realizada a amostragem média para execução dos ensaios de pega e resistência à compressão. Vale ressaltar que na preparação de amostras para os ensaios, foram realizadas homogeneização e quarteamento. 


\subsection{Ensaios de Caracterização Tecnológica}

\subsubsection{Espectrometria de Fluorescência de Raios-X}

A técnica de Fluorescência de Raios-X se baseia na absorção pela matéria o que gera excitação dos átomos e emissão de radiação eletromagnética na faixa de comprimento de raios-X. Esta é uma radiação característica, porque esta está relacionada com o tipo de átomo envolvido.

O equipamento utilizado foi o Espectrômetro de Fluorescência de Raios-X da série DY $\mathrm{n}^{\circ} 1122$ localizado na unidade Votorantim em Cantagalo no estado do Rio de Janeiro.

\subsubsection{Difração de Raios-X}

A técnica de Difração de Raios-X é baseada no processo de interferência construtiva causada pela incidência de um feixe de Raios $X$ em direção a um a material com estrutura atômica periodicamente arranjada no espaço, característica de uma estrutura cristalina.

A redução das amostras a um pó muito fino de farinha, pó de retorno e clínquer foi realizada no moinho vibratório de micronização de partículas da marca MaCrone (Figura 31) como pode ser observado na figura abaixo. Para preservar as amostras de forma que não haja deformação estrutural nos cristais pela energia decorrente da moagem, os materiais foram misturados com álcool isopropílico a 99\%. O tempo de moagem foi de 10 minutos. Após a moagem, as amostras foram submetidas a secagem na estufa durante 24 horas. Depois de secas, foram trituradas pelo gral. As amostras estavam passantes a 600 mesh. A preparação dessas amostras foi realizada no Centro Tecnológico da Mineração localizado na Cidade Universitária do Rio de Janeiro. 


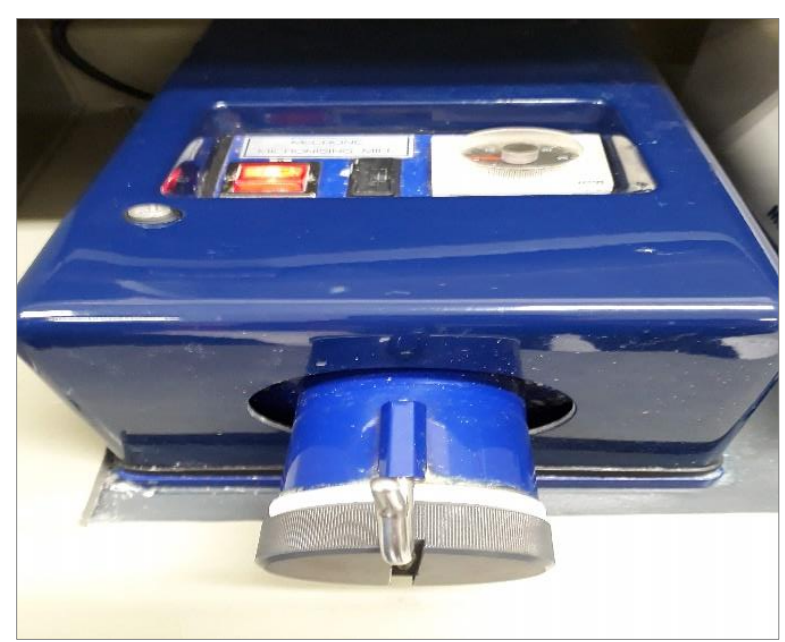

Figura 31-Moinho Vibratório McCrone

Fonte: CETEM

As amostras preparadas foram analisadas no Difratômetro D8-Discover da marca BRUKER localizado no Departamento de Engenharia de Processos Químicos e de Materiais da PUC-Rio. As condições de análise foram:

Tabela 13 - Condições operacionais da difração de raios X

Análise Quantitativa (Método de Rietveld)

Geometria Bragg- Brentano (1 $\theta-2 \theta$ acoplada)

Filtro de $\mathrm{Ni}$, tubo $\mathrm{Cu}$

Tensão e corrente do tubo - $40 \mathrm{KV}$ e $40 \mathrm{~mA}$

Passo $2 \theta-0,02^{\circ}$

Tempo por ângulo-0,5 s (farinha e pó de retorno) e 2 s(clínquer)

Detetor - LynxEye 


\subsubsection{Método de Rietveld}

Existem dois métodos quantitativos de análise do difratograma. A primeira se baseia na sua decomposição em difratogramas individuais. Trata-se do conhecimento das formas e posições dos picos de difração que não requer informação estrutural ou da composição. Assim, uma vez separado em padrões individuais, se atribuem às áreas integradas a cada componente (La Torre, 2003).

Já o segundo método é o chamado Rietveld que considera o difratograma total como uma soma de padrões individuais sem realizar separação em componentes. A partir desta ideia, o método é utilizado para refinamento das estruturas cristalinas por meio de dados de difração de nêutrons (La Torre, 2003).

O refinamento consiste na minimização da diferença entre o difratograma calculado e o experimental que não utiliza a integração de áreas e sim o ajuste ponto a ponto $(2 \theta)$ do calculado com o experimental. Isto evita a intensa sobreposição de raias das principais fases do clínquer, concentradas em um intervalo angular de $2 \theta$ $25^{\circ}$ a $50^{\circ}(\mathrm{Cu} \mathrm{K \alpha})$, somadas à presença de diversos polimorfos e aos problemas de cristalinidade tornam as quantificações utilizando esses parâmetros impossíveis (Taylor et al, 1999 apud Pecchio).

A minimização pelo método dos mínimos quadrados, fazendo um ajuste dos parâmetros fundamentais de difração de Raios-X (DRX), permite a obtenção de resultados quantitativos. Desta forma, baseando-se nas áreas relativas das fases presentes, a partir da DRX, quantifica percentualmente em massa das fases presentes, deformações da rede cristalina e distribuição de tamanho dos grãos.

A qualidade do refinamento é verificada através de indicadores estatísticos que são utilizados durante o processo iterativo (cálculos) e após o término deste, para verificar se o refinamento está sendo realizado de forma satisfatória. São utilizados os seguintes indicadores: $\mathrm{R}_{\mathrm{wp}}$ (perfil em peso residual) e GOF (Goodness of Fit) que estão com suas fórmulas descritas abaixo:

$$
\begin{array}{r}
R w p=100 x \sqrt{\frac{\sum_{i=1}^{n} w i(y i(o)-y i(c))^{2}}{\sum_{i=1}^{n} w_{i} y_{i(o)}^{2}}} \\
\mathrm{Yi}(\mathrm{o})=\text { valor observado } \\
\mathrm{Yi}(\mathrm{c})=\text { valor calculado }
\end{array}
$$


wi $=$ peso de cada dado

$$
\begin{aligned}
& \operatorname{Rexp}=\left[\frac{(N-P)}{\sum w_{i y_{i o}^{2}}}\right] \\
& \qquad \begin{array}{l}
\mathrm{N}=\text { número de parâmetros sendo refinados } \\
\mathrm{P}=\text { número de observações }
\end{array}
\end{aligned}
$$

$$
G O F=\frac{R w p}{R \exp }=X^{2}
$$

O perfil em peso residual representa o somatório da diferença entre dados calculados e observados sobre o somatório de todos os pontos. Já o goodness-of-fit (GOF) é definido pela razão entre $\mathrm{R}_{\mathrm{wp}}$ e $\mathrm{R}_{\exp }$ (valor estatisticamente esperado para o $R_{w p}$ ) para todos e para cada ponto do difratograma e deve ser equivalente a 1,0 em um refinamento ideal (Pecchio, 2013).

Aplicou-se o método de Rietveld aos difratogramas das amostras de farinha, pó de retorno e clínquer utilizando o programa TOPAS versão 2.1.

\subsubsection{Microscopia Ótica}

Os microscópicos são dispositivos dotados de um sistema ótico complexo, cuja principal finalidade é a de possibilitar a visualização de detalhes e feições de materiais de dimensões reduzidas, cuja observação macroscópica não é possível. Existem dois tipos básicos de microscópico ótico segundo o tipo de iluminação: o de luz refletida e o de luz transmitida. Como o material analisado neste trabalho é o clínquer cuja característica é ser opaco (não permite a perfeita passagem de luz), será usado o microscópico de luz refletida (ABCP, 2004).

A técnica microscópica ótica para indústria cimenteira consiste no estudo das características texturais e estruturais dos constituintes mineralógicos do clínquer, permitindo estabelecer suas condições de fabricação e verificação de possíveis anormalidades (ABCP, 2004). Na década de 70, a técnica se intensificou pelas 
indústrias brasileiras, tornando-se uma importante ferramenta no controle de qualidade nas fábricas de cimento (Gobbo,2003).

A observação microscópica do clínquer por luz refletida pode ser dividida em dois campos: um qualitativo referente a formação, natureza e distribuição dos constituintes e outro quantitativo, relativo às medições por análise modal dos compostos. A análise qualitativa é baseada em fatores estruturais como forma de distribuição, morfologia e dimensão dos cristais, polimorfismo, entre outros que exercem forte influência sobre as propriedades do clínquer (Gobbo, 2003). O estudo microscópico do clínquer é realizado na identificação dos quatro constituintes: $C_{3} S$, $\mathrm{C}_{2} \mathrm{~S}, \mathrm{C}_{3} \mathrm{~A}$ e $\mathrm{C}_{4} \mathrm{AF}$. Quanto ao cal livre e ao periclásio, esses são fases secundárias residuais sem atividade hidráulica.

Para preparação das amostras, foi realizada uma amostragem pontual por meio da seleção de três grãos de clínquer do Forno 2. Posteriormente, foram elaboradas seções polidas com a utilização da resina para embutimento de forma que os poros sejam preenchidos e facilite sua observação. Após o endurecimento, foram realizados os lixamentos com números de 220, 320, 400 e 600, utilizando como meio lubrificante álcool isopropílico. $\mathrm{Na}$ sequência, as amostras foram polidas em discos apropriados com pasta de diamante. Foi utilizado o microscópico ótico da marca Olympus BH- 2 localizado na Votorantim Cantagalo e da marca ZEISS Axio Lab.A1 no Laboratório de Metalografia da PUC-Rio. As diferentes feições do clínquer e sua textura foram reveladas por meio do uso de reagentes químicos que respondem de modo diferente em cada uma das fases conforme apresentados na Tabela 14. 
Tabela 14 - Resposta ao ataque dos reagentes químicos

\begin{tabular}{|c|c|c|c|c|c|c|c|}
\hline \multirow{2}{*}{ Reagente } & \multirow{2}{*}{ Concentração } & \multirow{2}{*}{$\begin{array}{c}\text { Tempo de } \\
\text { ataque }\end{array}$} & \multirow{2}{*}{ Tipo } & \multicolumn{4}{|c|}{ Resposta } \\
\hline & & & & Alita & Belita & $\mathrm{C}_{3} \mathrm{~A}$ & Ferrita \\
\hline $\mathrm{NH}_{4} \mathrm{Cl}$ & $0,1 \%$ & $8 s$ & Colorimétrico & $* * *$ & $* *$ & - & - \\
\hline \multirow[t]{2}{*}{$\mathrm{HNO}_{3}$} & $1 \%$ & $4 s$ & Colorimétrico e & $* *$ & $* * *$ & - & - \\
\hline & & & Estrutural & & & & \\
\hline
\end{tabular}

A tabela 15 mostra a forma/tamanho dos cristais de cada constituinte principal do clínquer e o respectivo diagnóstico do processo no microscópico.

Tabela 15 - Forma e estrutura dos cristais

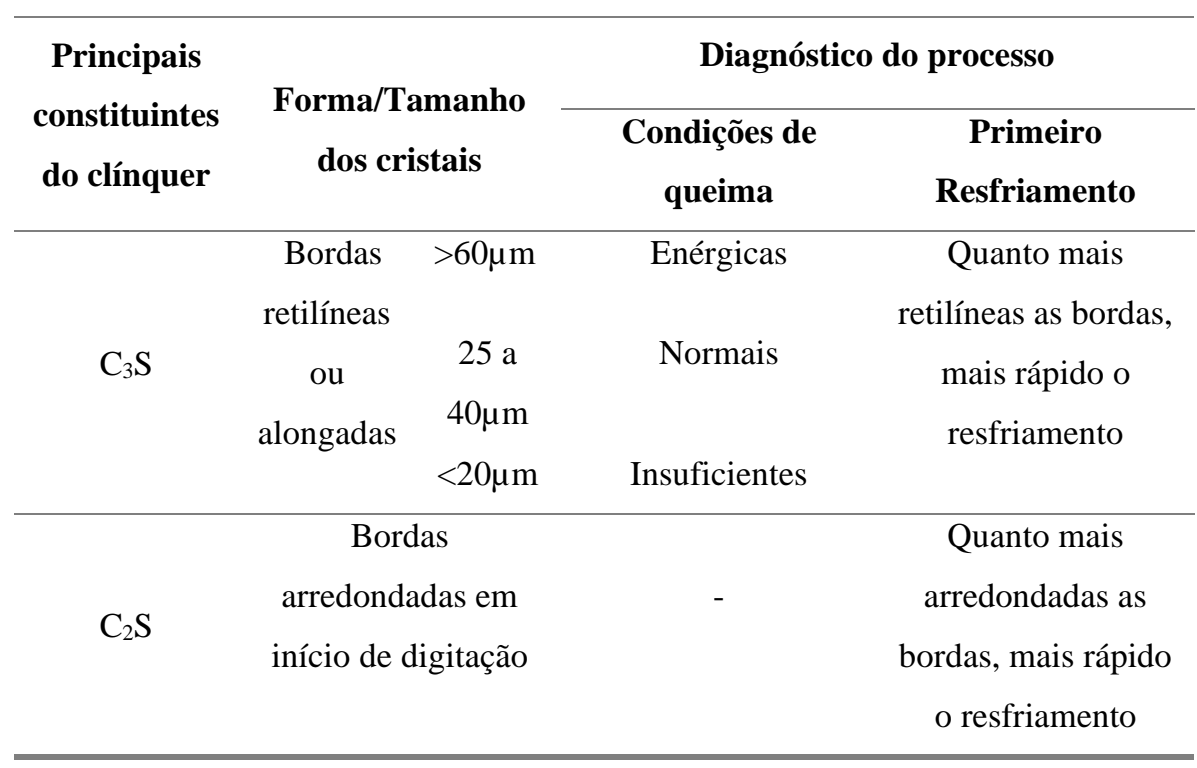

-Cúbica-

equidimensionais

-Orthorômbica- Segundo Resfriamento - lento

$\begin{array}{ccc}\mathrm{C}_{3} \mathrm{~A} / \mathrm{C}_{4} \mathrm{AF} & \text { ripas geminadas } & \\ \text { (fase } & & \\ \text { intersticial) } & \text { Má formação de } & \\ \text { *Não podem } & \mathrm{C}_{3} \mathrm{~A} \text { e inter- } & \text { Segundo Resfriamento -normal } \\ \text { ser } & \text { crescidos com } & \\ \text { observados } & \mathrm{C}_{4} \mathrm{AF} & \\ & * \text { Muito pequenos e } & \\ & \text { mal formados) } & \text { Segundo Resfriamento- rápido }\end{array}$




\subsection{Caracterização do clínquer utilizando a abordagem PCA}

Foram tomadas 30 observações equivalentes a um mês de operação do Forno 2 da Votorantim Cantagalo e 45 variáveis para utilizar a técnica multivariada PCA. O programa utilizado foi o Past 3.25.

São tomados os seguintes componentes de entrada e saída no sistema Forno de Clínquer para análise da correlação estatística:

\section{Componentes de entrada (E)}

- Farinha (E1)

$\checkmark$ Composição química (Teores de $\mathrm{SiO}_{2}, \mathrm{CaO}, \mathrm{Al}_{2} \mathrm{O}_{3}, \mathrm{Fe}_{2} \mathrm{O}_{3}$, $\mathrm{SO}_{3}, \mathrm{~K}_{2} \mathrm{O}, \mathrm{Na}_{2} \mathrm{O}$ e $\mathrm{MgO}$ em \%)-Subtotal de 8 variáveis;

- Combustível (E2)

$\checkmark$ Consumo $(\%)$

$\checkmark$ Finura (\#170)

$\checkmark$ Teor de $\mathrm{SO}_{3}(\%)$

$\checkmark$ Teor de Cinzas (\%)

$\checkmark$ PCS (Poder Calorífico Superior-Kcal/kg)-Subtotal de 5 variáveis;

- Resíduo CSS50 (E3)

$\checkmark$ Consumo $(\%)$

$\checkmark$ Teor de Umidade(\%)-Subtotal de 2 variáveis;

- Resíduo Líquido (E4)

$\checkmark$ Consumo (\%) - Subtotal de 1 variável;

- Resíduo de pneu (E5)

$\checkmark$ Consumo (\%) - Subtotal de 1 variável; 
- Parâmetros operacionais (E6)

$\checkmark$ Corrente do motor principal (\%)

$\checkmark$ Grau de enchimento (\%)

$\checkmark$ Rotação do forno (rpm)

$\checkmark$ Teor de $\mathrm{CO}(\mathrm{ppm})$

$\checkmark$ Teor de $\mathrm{NO}_{2}(\mathrm{ppm})$

$\checkmark$ Teor de $\mathrm{SO}_{2}(\mathrm{ppm})$

$\checkmark$ Temperatura de entrada no forno $\left({ }^{\circ} \mathrm{C}\right)$

$\checkmark$ Temperatura da saída da zona de resfriamento $\left({ }^{\circ} \mathrm{C}\right)$

$\checkmark$ Temperatura da saída dos gases $1\left({ }^{\circ} \mathrm{C}\right)$

$\checkmark$ Temperatura da saída dos gases $2\left({ }^{\circ} \mathrm{C}\right)$

$\checkmark$ Temperatura do ar secundário $\left({ }^{\circ} \mathrm{C}\right)$ - Subtotal de 11 variáveis;

\section{Componentes de saída (S)}

- Clínquer (S)

$\checkmark \quad$ Produção (toneladas)

$\checkmark$ Composição química (Teores de $\mathrm{SiO}_{2}, \mathrm{CaO}, \mathrm{Al}_{2} \mathrm{O}_{3}, \mathrm{Fe}_{2} \mathrm{O}_{3}, \mathrm{SO}_{3}$, $\mathrm{K}_{2} \mathrm{O}, \mathrm{Na}_{2} \mathrm{O}$ e $\mathrm{MgO}$ em \%);

$\checkmark$ Teor de alita (M1 e M3 em \%);

$\checkmark$ Teor de belita (\%);

$\checkmark$ Teor de $\mathrm{C}_{3} \mathrm{~A}$ (cúbica e orthorômbica-\%)

$\checkmark$ Teor de $\mathrm{C}_{4} \mathrm{AF}$

$\checkmark$ Teor de Periclásio (MgO livre-\%)

$\checkmark$ Teor de Cal livre(\%) - Subtotal de 17 variáveis;

Antes de executar o processamento de dados no programa Past 3.25, foram normalizados os dados para retirar a diferença de unidades e ordem de grandeza das variáveis para não interferir nos resultados conforme item 2.5.2.1. 


\subsection{Ensaios de Desempenho Físico-Mecânico}

As reações de hidratação denotam a totalidade da mudança que ocorrem quando um cimento anidro, ou uma das fases constituintes, é misturado com água. Estas reações se apresentam mais complexas do que outras conversões mais simples. Uma mistura de cimento e água em tais proporções que pegam e endurecem é chamada de pasta. A relação água/cimento (w/c) ou água/sólido (w/s) se referem a proporções de massa; para uma pasta, é tipicamente 0.3-0.6. As condições em que estas reações de hidratação estão suscetíveis, ou seja, as reações ocorrem em câmara úmida e com alta umidade de ar. Pega é enrijecimento sem desenvolvimento significativo de resistência a compressão, e tipicamente ocorre em poucas horas. Endurecimento é desenvolvimento significativo de resistência a compressão, e é normalmente um processo mais lento (Taylor, 1997).

Em relação a resistência a compressão de uma pasta de cimento, pode-se citar alguns fatores que influenciam esta propriedade.

- as características do cimento, tal como composição do clínquer e microestrutura, conteúdo do gesso e distribuição do tamanho da partícula;

- a razão w/c (water-cement) e os conteúdo de gesso e os conteúdos de ar e de algumas misturas presentes no mix;

- condições de mistura;

- condições de cura, especialmente temperatura e RH;

- a idade;

- a maneira de testar, inclui o conteúdo da água da espécie.

Além da resistência aos 28 dias que define a classe do cimento, foram realizados os ensaios nas idades de 3 e 7 dias conforme norma ABNT NBR 16697, além de 1 dia exigido apenas para CPVARI. Quanto ao ensaio de início de pega, há um valor mínimo de 60 minutos para todos os tipos de cimento normatizados.

A execução dos ensaios de resistência a compressão e início e fim de endurecimento do cimento atendem às normas ABNT NBR 725 e 16607, respectivamente. 


\subsection{Caracterização tecnológica da farinha, pó de retorno e clínquer}

\subsubsection{Composição química}

As Tabela 16 mostra as análises químicas completas da farinha, pó de retorno e clínquer, respectivamente, realizada pelo método de Espectrometria de Fluorescência de Raios-X.

Tabela 16 - Composição Química dos insumos

\begin{tabular}{cccc}
\hline $\begin{array}{c}\text { Composição } \\
\text { Química }\end{array}$ & Farinha & Pó de retorno & Clínquer \\
\hline $\mathrm{CaO}$ & 43,93 & 45,93 & 66,77 \\
\hline $\mathrm{SiO}_{2}$ & 13,71 & 7,31 & 20,84 \\
\hline $\mathrm{Al}_{2} \mathrm{O}_{3}$ & 3,45 & 4,15 & 5,24 \\
\hline $\mathrm{Fe}_{2} \mathrm{O}_{3}$ & 1,66 & 1,79 & 2,52 \\
\hline $\mathrm{MgO}$ & 1,18 & 0,82 & 1,79 \\
\hline $\mathrm{SO}_{3}$ & 0,39 & 0,95 & 0,59 \\
\hline $\mathrm{K}_{2} \mathrm{O}$ & 0,42 & 0,42 & 0,64 \\
\hline $\mathrm{Na}_{2} \mathrm{O}$ & 0,14 & 0,12 & 0,21 \\
\hline $\mathrm{PF}(\mathrm{Perda}$ ao fogo $)$ & 34,67 & 37,73 & -
\end{tabular}

O pó de retorno como é o próprio material cru que retorna ao processo, então tem uma composição semelhante à farinha, exceto o teor de $\mathrm{SiO}_{2}$. Este é reduzido para metade neste último. Isto é devido a característica do processo de clinquerização onde há perda de pó no momento em que este é "puxado" pelo exaustor até o filtro de despoeiramento. 
Com relação a composição do clínquer, há um aumento significativo do $\mathrm{CaO}$ e $\mathrm{SiO}_{2}$ em função da incorporação de cinzas do combustível sólido e do resíduo de $\mathrm{CaCO}_{3}$.já que o grau de descarbonatação não é $100 \%$.

\subsubsection{Composição mineralógica}

\subsubsection{Difratogramas}

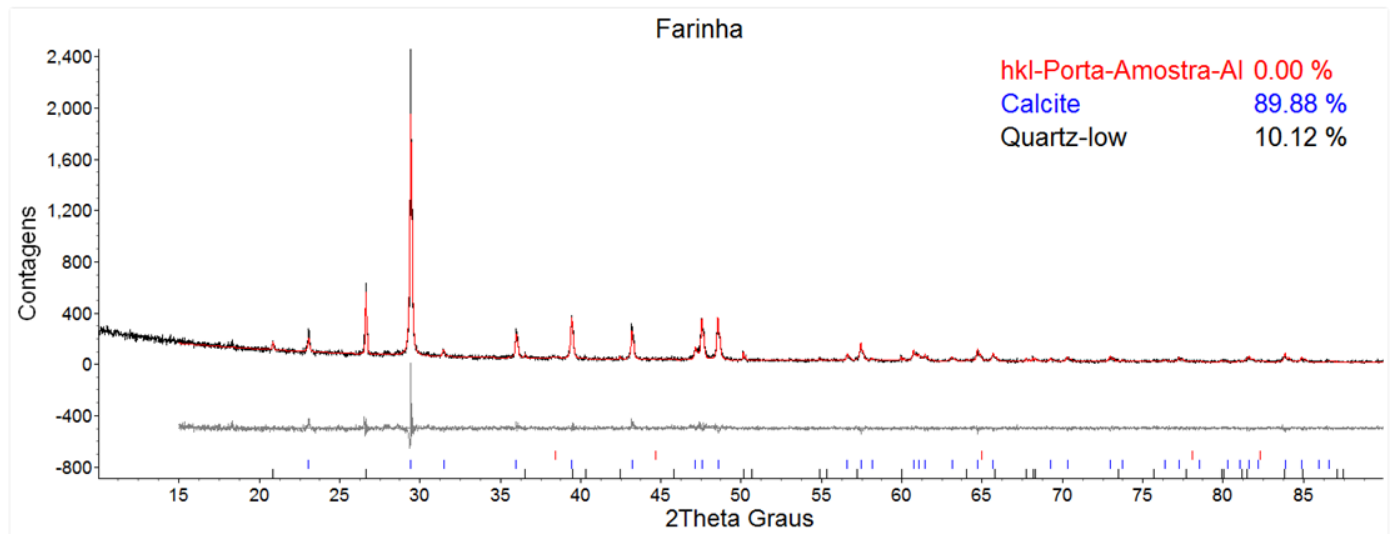

Figura 32- Difratograma da farinha

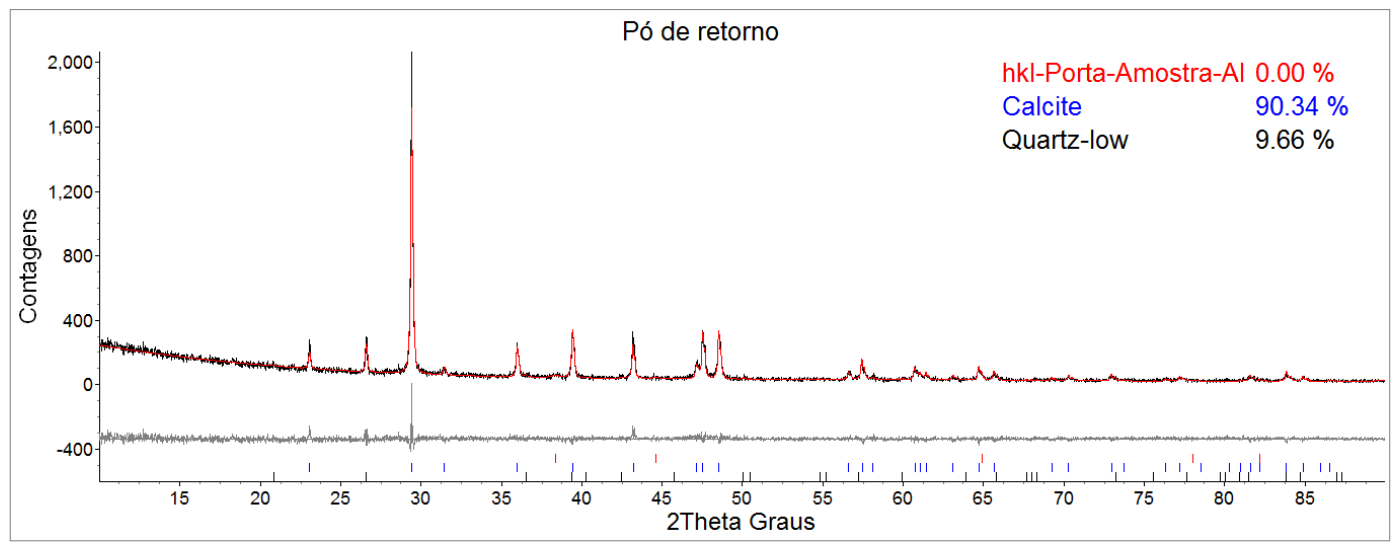

Figura 33- Difratograma do pó de retorno 


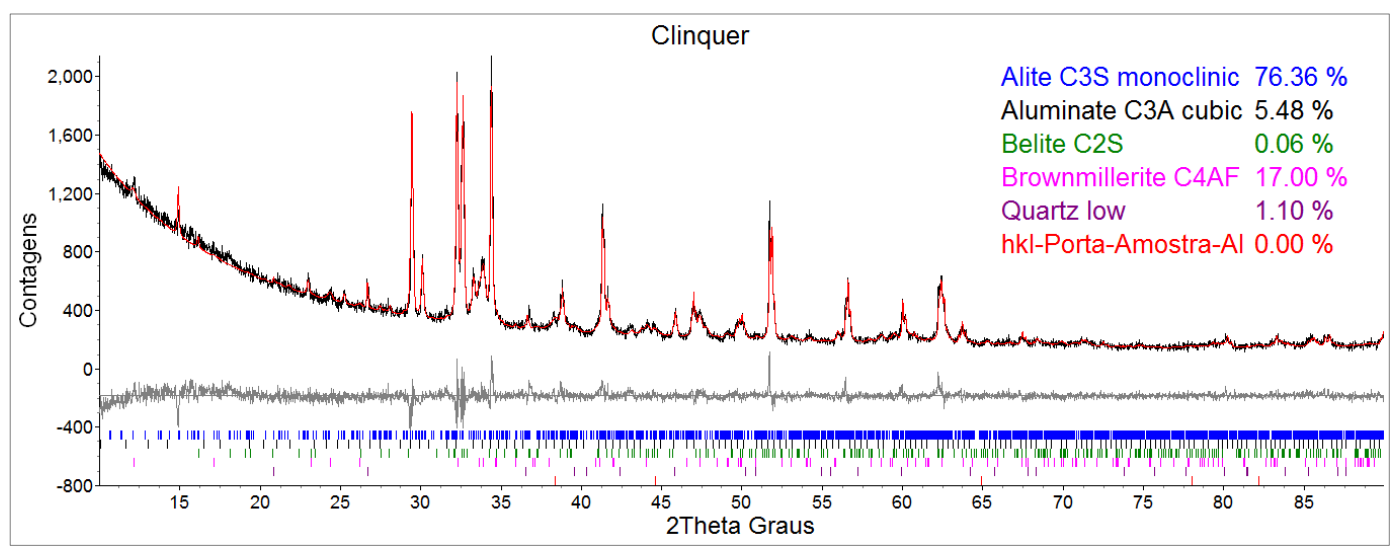

Figura 34-Difratograma do clínquer

De acordo com a varredura automática dos picos das estruturas cristalinas proveniente do refinamento, identificou-se a calcita e o quartzo que apresentam percentuais de 90 e 10\% na farinha e pó de retorno (Figuras 32 e 33).

Quanto ao clínquer (Figura 34), é possível observar os principais constituintes: $\mathrm{C}_{3} \mathrm{~S}, \mathrm{C}_{2} \mathrm{~S}, \mathrm{C}_{3} \mathrm{~A}$ e $\mathrm{C}_{4} \mathrm{AF}$. O difratograma demonstra também a forma predominante do $\mathrm{C}_{3} \mathrm{~S}$ que é o monoclínico, muito comum em clínqueres industriais e a estrutura predominante do $\mathrm{C}_{3} \mathrm{~A}$ cuja forma é a cúbica. A Tabela 17 demonstra uma comparação entre os valores determinados pela difração e os compostos potenciais de Bogue.

Tabela 17 - Comparação de valores de potenciais de Bogue com Difração de Raios

\begin{tabular}{ccc} 
Constituintes & $\begin{array}{c}\text { Potenciais de Bogue } \\
(\boldsymbol{\%})^{\mathbf{1}}\end{array}$ & Difração de Raios (\%) \\
\hline $\mathrm{C}_{3} \mathrm{~S}$ & 75,87 & 76,36 \\
\hline $\mathrm{C}_{2} \mathrm{~S}$ & 1,83 & 0,06 \\
\hline $\mathrm{C}_{3} \mathrm{~A}$ & 8,22 & 5,48 \\
\hline $\mathrm{C}_{4} \mathrm{AF}$ & 11,63 & 17,00 \\
\hline
\end{tabular}

${ }^{1}$ Fórmulas Potencias de Bogue:

$\mathrm{C}_{3} \mathrm{~S}=4,0710 \mathrm{CaO}-7,6024 \mathrm{SiO}_{2}-6,7187 \mathrm{Al}_{2} \mathrm{O}_{3}-1,4297 \mathrm{Fe}_{2} \mathrm{O}_{3}$

$\mathrm{C}_{2} \mathrm{~S}=-3,0710 \mathrm{CaO}+8,6024 \mathrm{SiO}_{2}+5,0683 \mathrm{Al}_{2} \mathrm{O}_{3}+1,0785 \mathrm{Fe}_{2} \mathrm{O}_{3}=2,8675 \mathrm{SiO}_{2}-$ $0,7544 \mathrm{C}_{3} \mathrm{~S}$

$\mathrm{C}_{3} \mathrm{~A}=2,6504 \mathrm{Al}_{2} \mathrm{O}_{3}-1,6920 \mathrm{Fe}_{2} \mathrm{O}_{3}$

$\mathrm{C}_{4} \mathrm{AF}=3,0432 \mathrm{Fe}_{2} \mathrm{O}_{3}$

É possível observar que o valor de $\mathrm{C}_{2} \mathrm{~S}$ quase não é detectado pela difração. Como há uma dificuldade de detecção de concentrações muito baixas, então de fato o valor de $\mathrm{C}_{2} \mathrm{~S}$ é quase nulo. No caso do $\mathrm{C}_{3} \mathrm{~A}$, a difração resultou num valor $33 \%$ a menos em relação a Bogue enquanto que o $\mathrm{C}_{4} \mathrm{AF}, 46 \%$ a mais. 
Os potenciais de Bogue são referências teóricas dos valores dos principais constituintes do clínquer. Este método só leva em consideração as quatro principais fases do clínquer (cal livre e periclásio, por exemplo, não são consideradas). Além disso, as condições operacionais que podem influenciar na composição do clínquer não são consideradas também.

\subsubsection{Método de Rietveld}

Os valores de indicadores estatísticos Rexp, Rwp e GOF encontram-se na Tabela 18 para os três pontos:

Tabela 18 - Indicadores do refinamento

\begin{tabular}{cccccc} 
& $\mathbf{R}_{\text {expmin }}$ & $\mathbf{R}_{\operatorname{expmax}}$ & $\mathbf{R}_{\text {wpmin }}$ & $\mathbf{R}_{\text {wpmax }}$ & $\mathbf{G O F}$ \\
\hline Farinha & 12,43 & 28,21 & 14,91 & 33,83 & 1,20 \\
\hline Pó de retorno & 11,69 & 30,09 & 13,54 & 34,82 & 1,16 \\
\hline Clínquer & 3,59 & 5,13 & 5,10 & 7,28 & 1,42
\end{tabular}

Deve-se considerar que $\mathrm{R}_{\text {exp }}$ é função de qualidade dos difratogramas e das estatísticas de contagem. Desse modo, altos valores de $\mathrm{R}_{\exp }$, ou difratogramas de baixa qualidade, podem originar baixos valores de GOF sem que se obtenha um bom ajuste de modelo. De modo inverso, um bom ajuste do refinamento para um difratograma de boa qualidade, com baixo valor de $\mathrm{R}_{\exp }$, pode resultar elevados valores de GOF sem que se obtenha um bom ajuste do modelo. De modo inverso, um bom ajuste do refinamento para um difratograma de alta qualidade, com baixo valor de $\mathrm{R}_{\exp }$, pode resultar elevados valores de GOF (Pecchio, 2013). Sendo assim, a análise mais adequada é pelo $\mathrm{R}_{\mathrm{wp}}$. 


\subsubsection{Análise Microestrutural}

\subsubsection{Microscopia ótica}

As Figuras 35 a 42 ilustram feições das seções observadas no microscópio óptico de luz refletida. Cada figura demonstra a microestrutura do clínquer e a indicação das condições operacionais do processo.

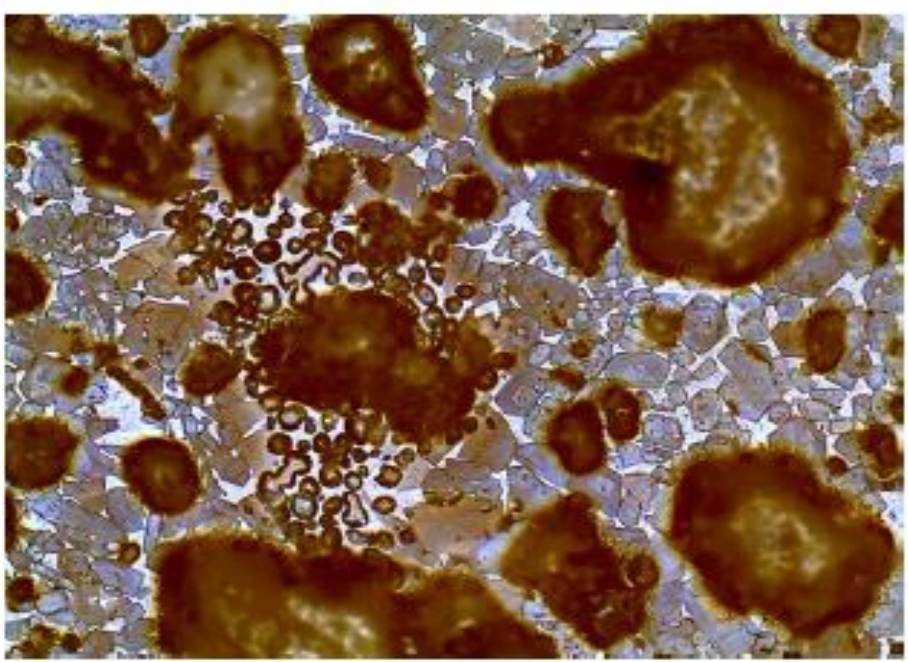

Figura 35-Pouca frequência de zonas regulares de $\mathrm{C}_{2} \mathrm{~S}$ Ataque químico com $\mathrm{NH}_{4} \mathrm{Cl} 0,1 \%$.

$\mathrm{Na}$ Figura 35, é possível observar zonas regulares de $\mathrm{C}_{2} \mathrm{~S}$ indicando leve deficiência de moagem para grãos de $\mathrm{SiO}_{2}$. Numa moagem adequada de grãos de $\mathrm{SiO}_{2}$, os cristais são idiomórficos, vítreos e normalmente arredondados sem formar aglomerações. $\mathrm{O}$ tamanho está entre 1 e $4 \mu \mathrm{m}$ abaixo de $1300^{\circ} \mathrm{C}$, mas recristaliza a alta temperatura (aproximadamente $1500^{\circ} \mathrm{C}$ ). Quanto à densidade, o valor está em torno de 3,07 mg/m³ (Campbell, 1999). 


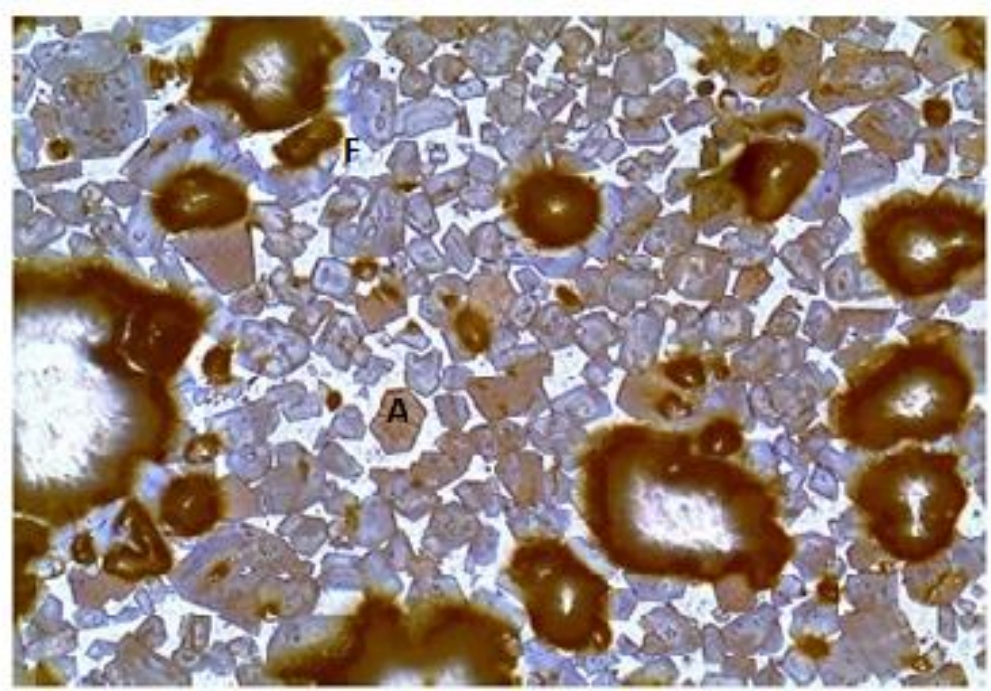

Figura 36-Cristais Equidimensionais de alita (A) e fase intersticial (F)

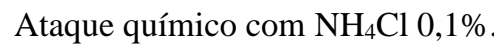

A Figura 36 mostra os cristais equidimensionais ou alongados de alita (A) com diâmetro de $30,5 \mu \mathrm{m}$ - dentro do intervalo de tamanho normal entre 25 e 40 $\mu \mathrm{m}$ - com formatos hexagonais, vítreos e compactos. Isto indica uma temperatura normal de clinquerização. Quanto a densidade, esta está entre 3,13 e 3,22 $\mathrm{mg} / \mathrm{m}^{3}$ (Campbell,1999). É possível observar também a fase intersticial (F). Portanto, o $\mathrm{C}_{3} \mathrm{~S}$ é bastante reativo o que contribui para resistência alta em todas as idades.

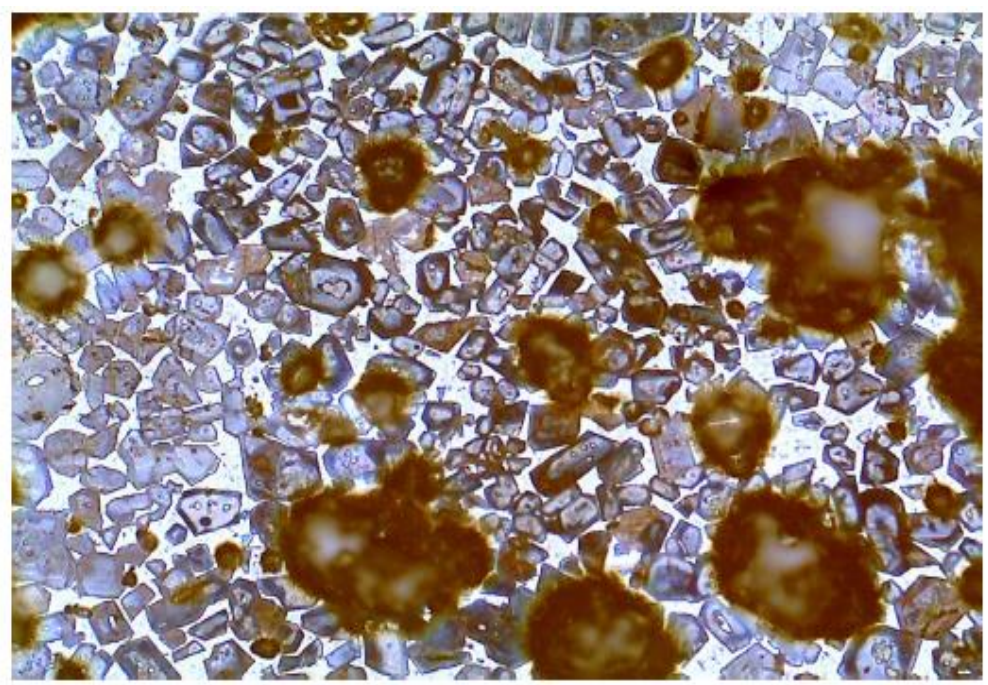

Figura 37-Cristais equidimensionais de $\mathrm{C}_{3} \mathrm{~S}$ Ataque químico com $\mathrm{NH}_{4} \mathrm{Cl} 0,1 \%$.

Quanto a Figura 37, esta apresenta as mesmas características da Figura anterior, ou seja, pode-se observar cristais alongados da alita com cerca de $30 \mu \mathrm{m}$ 
com formatos hexagonais, vítreos e compactos. Isto evidencia a alta reatividade do $\mathrm{C}_{3} \mathrm{~S}$ e contribui de forma significativa para alta resistência em todas as idades.

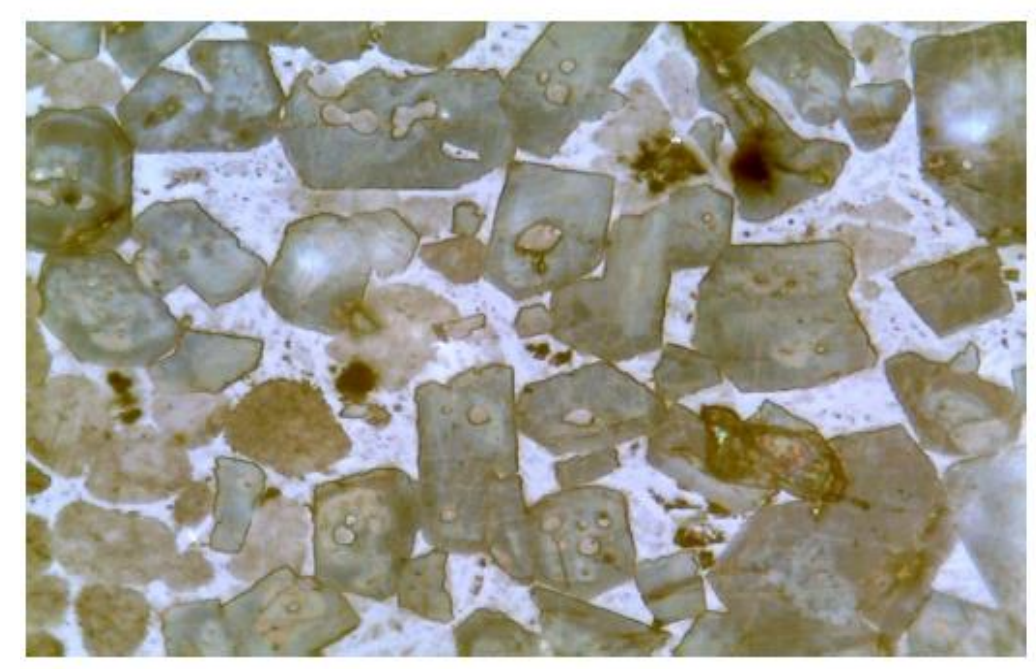

Figura 38- Cristais de $\mathrm{C}_{3} \mathrm{~S}$ subdiomórficos e $\mathrm{C}_{2} \mathrm{~S}$ em início de digitação

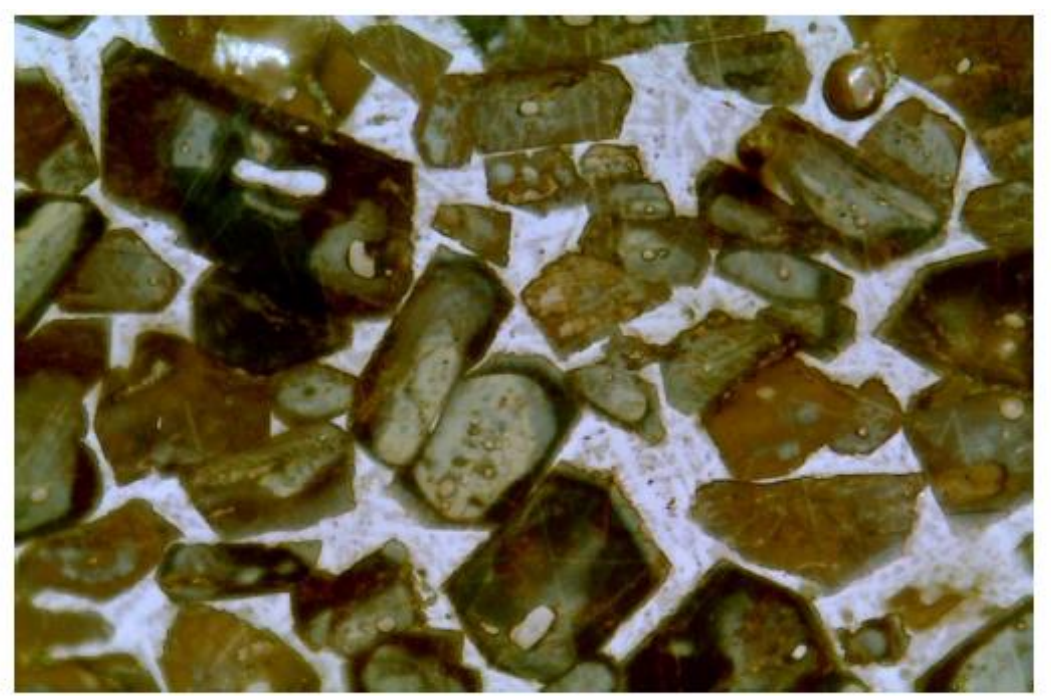

Figura 39-Fase intersticial semi-cristalizada

Quanto a Figura 38, os cristais de $\mathrm{C}_{3} \mathrm{~S}$ subdiomórficos e $\mathrm{C}_{2} \mathrm{~S}$ arredondada em início de digitação (pouco observados) indicam primeiro resfriamento de normal a lento. $\mathrm{O}$ primeiro resfriamento se refere às variações de estabilidade dos silicatos cálcicos (alita e belita). Quanto mais decompostos esses cristais, diz-se que o primeiro resfriamento é lento, e quanto mais retilíneas as bordas da alita e mais arredondada a belita, diz-se que o resfriamento é normal (Kihara,1976). 
A Figura 39 demonstra fase intersticial $\left(\mathrm{C}_{3} \mathrm{~A}\right.$ e $\left.\mathrm{C}_{4} \mathrm{AF}\right)$ semi-cristalizada que indica segundo resfriamento normal, cuja base é no grau de cristalização da fase intersticial. Assim, fases intersticiais vítrea, semi-cristalizada e cristalizada, caracterizam, respectivamente, um segundo resfriamento rápido, normal e lento (Kihara, 1976).

Além disso, é possível observar que os cristais de $\mathrm{C}_{3} \mathrm{~A}$ são mal formados $\mathrm{e}$ inter-crescidos com $\mathrm{C}_{4} \mathrm{AF}$. Por isso, não há como visualizar esses cristais separados num resfriamento normal. Diferente do resfriamento lento que obtém-se uma visualização dos cristais de $\mathrm{C}_{3} \mathrm{~A}$ em forma cúbica e de $\mathrm{C}_{4} \mathrm{AF}$ em forma orthorômbica. E finalmente, para um resfriamento rápido, os cristais são muito pequenos e mal formados e não podem ser observados.

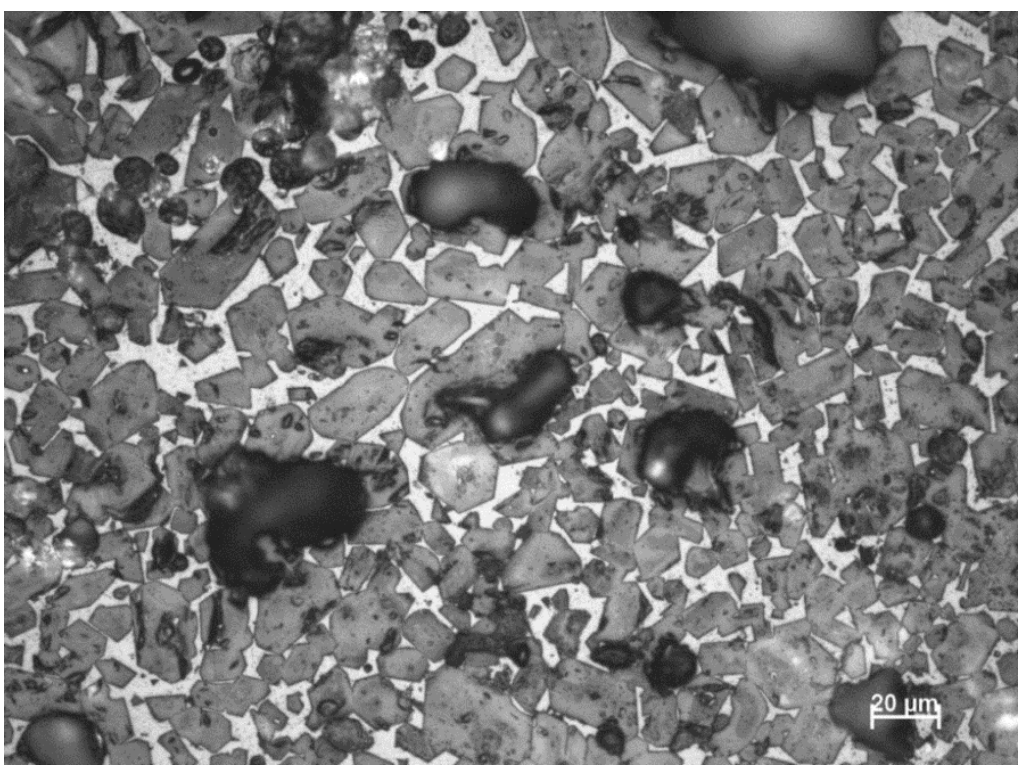

Figura 40-Cristais de C3S sub-retilíneas com leve início de digitação do $\mathrm{C}_{2} \mathrm{~S}$ Ataque químico de $\mathrm{HNO}_{3} 1 \%$.

Na Figura 40, é possível observar as feições dos cristais com visão mais clara de alita e belita com ataque de $\mathrm{HNO}_{3}$, já que este reagente favorece o ataque às estruturas. Então conforme já discutido, há indicação do primeiro resfriamento ser considerado normal a lento. 


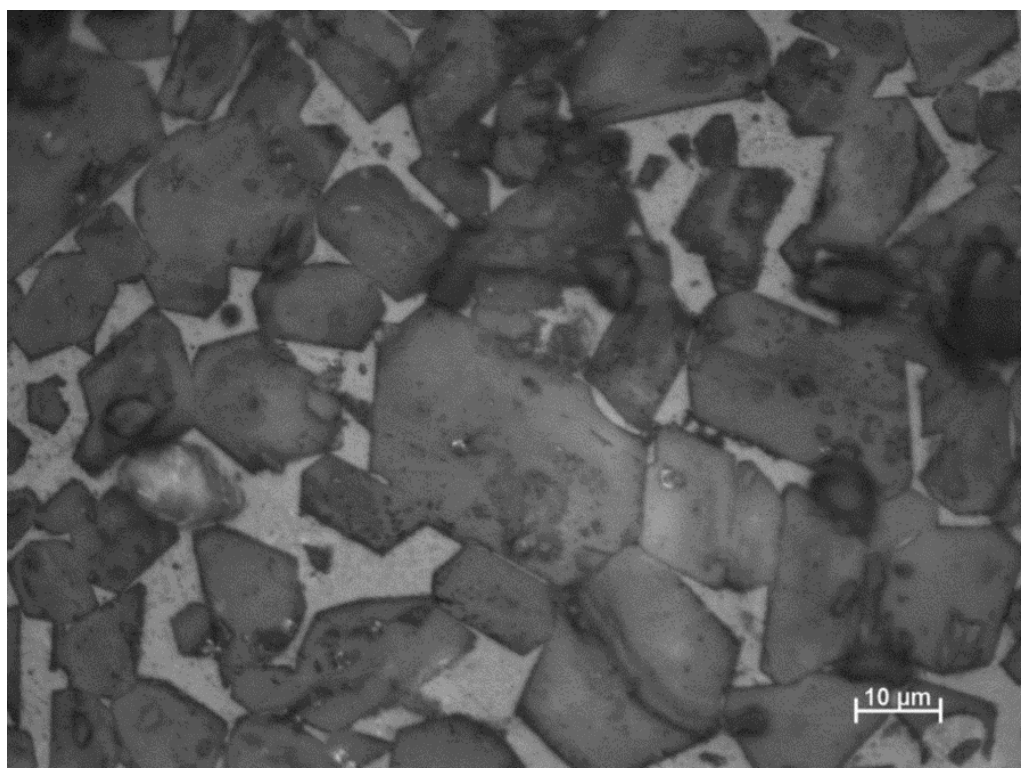

Figura 41-Fase semi-cristalizada sem distinção da fase intersticial Ataque químico de $\mathrm{HNO}_{3} 1 \%$.

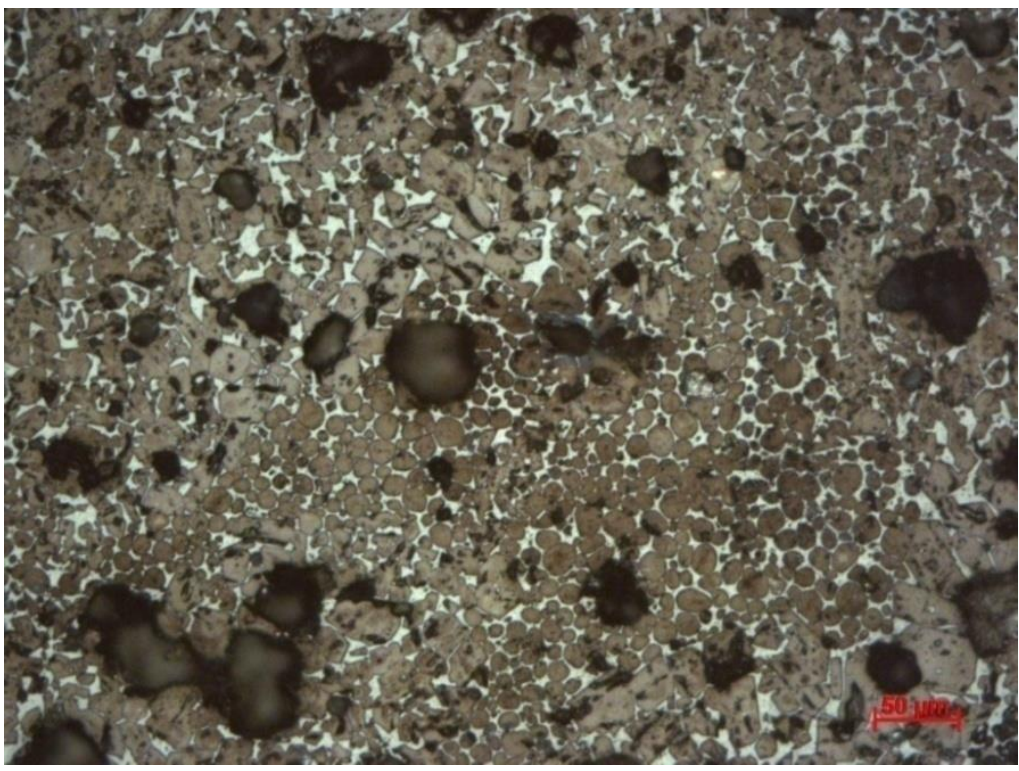

Figura 42-Poucas zonas regulares de belita.

Ataque químico de $\mathrm{HNO}_{3} 1 \%$.

A Figura 41 apresenta o grau de cristalização da fase intersticial com ataque químico de $\mathrm{HNO}_{3}$, conforme discutido antes, que indica segundo resfriamento normal a lento que se basea no grau de cristalização da fase intersticial.

Já a Figura 42 demonstra zonas regulares de cristais de belita, conforme discutido anteriormente, com ataque químico de $\mathrm{HNO}_{3}$ que indica leve deficiência de moagem de grãos de sílica. 


\subsection{Caracterização do clínquer pelo PCA}

Após a normatização dos dados de entrada e saída, estes foram inseridos conforme Figura 43:

\begin{tabular}{|c|c|c|c|c|c|c|c|c|c|}
\hline \multicolumn{8}{|c|}{ Dadospast250719.dat } & \multirow{2}{*}{\multicolumn{2}{|c|}{ Script Help }} \\
\hline $\begin{array}{l}\text { File Edit } \\
\text { Show }\end{array}$ & Transform & Plot Univariate & Multivariate & $\begin{array}{l}\text { Model Diversity } \\
\text { Edit }\end{array}$ & & Timeseries & $\begin{array}{l}\text { Stratigraphy } \\
\text { View }\end{array}$ & & \\
\hline \multirow{2}{*}{\multicolumn{2}{|c|}{$\begin{array}{l}\text { Show } \\
\square \text { Row attributes } \\
\square \text { Column attributes }\end{array}$}} & \multirow{2}{*}{$\begin{array}{l}\text { Click mode } \\
\text { Select } \\
\text { Drag rows/ }\end{array}$} & & कo cut & lie Pas & & $\square$ Bands & Recover wing & dows \\
\hline & & & :olumns & qe & (a) Sel & elect all & $\square$ Binary & Decimals: & - v \\
\hline & 国 sio2 & E1) $0 \mathrm{CaO}(\mathrm{E} 1)$ & O AI2O3(E & 1: 圆 Fe203(E1 & O SO3(E1) & O K2O(E1) & ) $\mathrm{NaZO}$ (E) & (1) $0 \mathrm{MgO}(\mathrm{E} 1)$ & O Conse \\
\hline Type & Ordinal & Ordinal & Ordinal & Ordinal & Ordinal & Ordinal & Ordinal & Ordinal & Ordinal \\
\hline Name & $\mathrm{SiO2}$ (E1) & $\mathrm{CaO}$ (E1) & A1203(E1) & $\mathrm{Fe} 2 \mathrm{O}$ (E1) & SO3(E1) & $\mathrm{K} 2 \mathrm{O}(\mathrm{E} 1)$ & $\mathrm{Na2O}$ (E1) & $\mathrm{MgO}(\mathrm{E} 1)$ & Consumo \\
\hline 1 & $\bullet 3,22$ & $-1,04$ & $-0,35$ & 2,42 & $-0,69$ & $-0,67$ & 1,34 & $-0,13$ & $-1,95$ \\
\hline 2 & - 0,44 & 0,28 & $-0,96$ & 1,82 & $-1,06$ & $-0,88$ & 0,91 & 0,14 & $-1,95$ \\
\hline 3 & $\cdot 2,28$ & 0,07 & $-0,57$ & 1,90 & $-1,06$ & $-0,76$ & 1,03 & $-0,64$ & $-1,95$ \\
\hline 4 & - 1,19 & 0,68 & $-1,01$ & 1,51 & $-1,25$ & $-1,31$ & 0,45 & $-0,79$ & $-1,95$ \\
\hline 5 & $\bullet 0,19$ & $-0,45$ & $-0,58$ & 1,60 & $-1,18$ & $-0,88$ & 0,60 & 0,14 & $-0,25$ \\
\hline 6 & - $-1,04$ & $-0,01$ & 1,31 & 1,16 & $-0,91$ & $-0,83$ & 0,29 & $-1,23$ & $-0,23$ \\
\hline 7 & $\bullet 0,77$ & 0.28 & 0.08 & $-0,40$ & $-1,03$ & 0,39 & 0.68 & $-1,69$ & $-0,24$ \\
\hline 8 & $\cdot-0,54$ & 1,99 & $-0,05$ & $-0,18$ & $-1,14$ & $-0,26$ & 0,83 & $-1,31$ & 0,42 \\
\hline 9 & - $-0,45$ & 1,22 & 0,26 & 0,02 & $-1,28$ & $-0,19$ & 0,90 & $-1,57$ & $-0,41$ \\
\hline 10 & $\cdot-0,21$ & 1,73 & 0,26 & 0,05 & $-1,23$ & -0.04 & L69. & $-1,48$ & $-0,28$ \\
\hline 11 & $\bullet 0,27$ & 0.62 & 0,96 & 0.12 & $-1,63$ & 0.01 & 1,41 & $-1,07$ & -0.88 \\
\hline 12 & - $-1,78$ & 0.18 & -2.51 & $-1,59$ & $-0,24$ & 0,30 & $-0,52$ & $-0,26$ & $-0,08$ \\
\hline 13 & $\bullet 0,50$ & 0,30 & $-0,44$ & $-0,81$ & $-0,21$ & 0,15 & $-1,46$ & 0,00 & $-1,13$ \\
\hline 14 & $\bullet 0,19$ & 0.61 & $-1,24$ & $-1,45$ & $-0,38$ & $-0,33$ & 0.22 & $-0,61$ & $-0,51$ \\
\hline 15 & - $-0,68$ & $-0,04$ & $-1,11$ & $-1,37$ & 0,29 & $-0,29$ & $-0,48$ & 0,77 & $-0,11$ \\
\hline 16 & $-0,67$ & $-1,31$ & $-1,21$ & $-1,01$ & 0,36 & $-1,11$ & $-1,39$ & 1.29 & 0.45 \\
\hline 17 & $\bullet 0,11$ & $-2,66$ & $-0,31$ & $-0,39$ & 0,38 & -0.97 & $-1,68$ & 0.65 & 0,30 \\
\hline 18 & - 0,15 & 0.34 & $-0,53$ & $-0,04$ & 0,30 & $-0,95$ & $-0,59$ & 1,31 & 1,14 \\
\hline
\end{tabular}

Figura 43-Dados inseridos no Past 3.25

Conforme procedimento de cálculos mencionados nos itens 2.5.2.2; 2.5.2.3 e 2.5.2.4, foram selecionados das 45 variáveis originais, um score de 29 componentes principais. De todos esses componentes principais, as variáveis mais representativas onde corresponde a maior parte da variância de todo o conjunto de dados são a faixa de PC1 ao PC8 com mais de 80\% do total (Figura 44). No entanto, serão selecionados para análise os três primeiros componentes principais ( $\mathrm{PC} 1, \mathrm{PC} 2$ e PC3), cujas correlações são bastante significativas (acima de 0,7 ). 


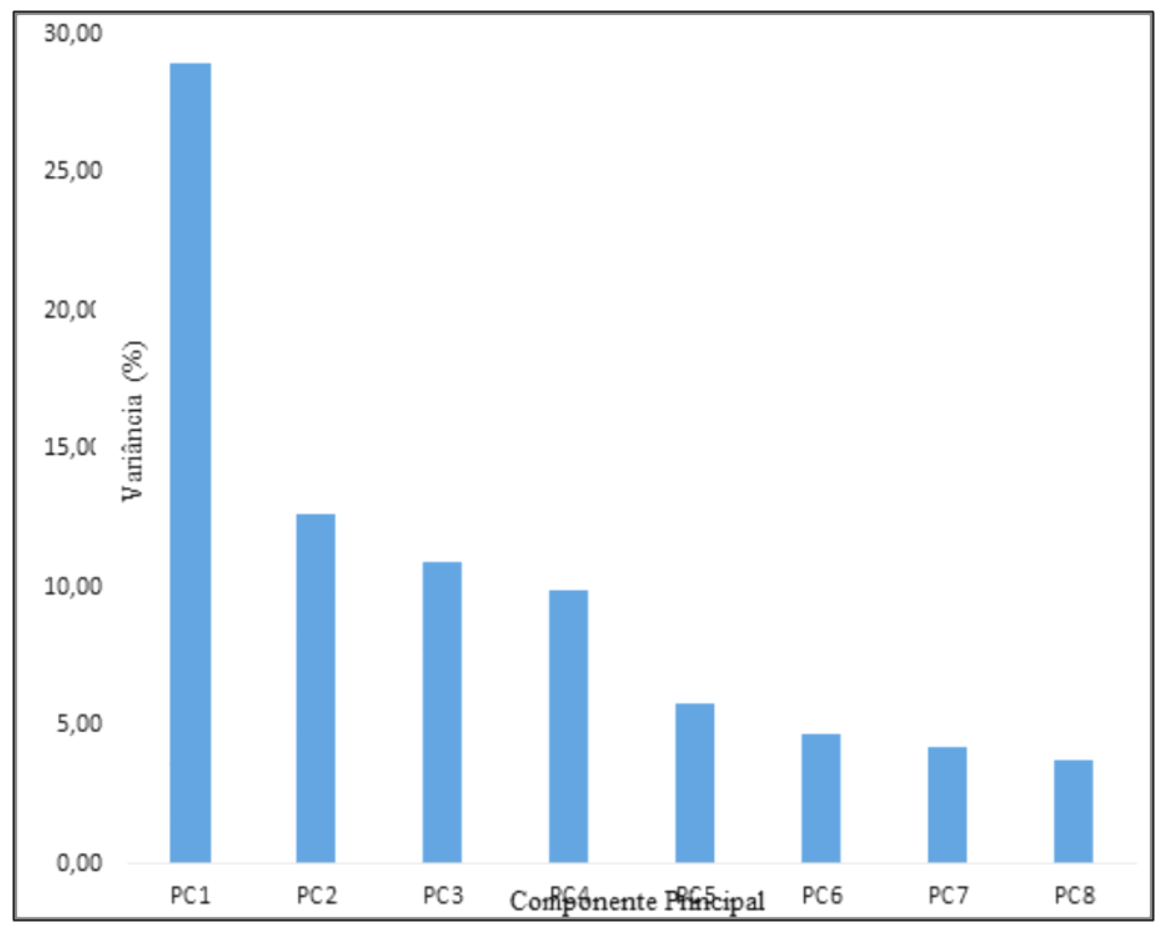

Figura 44-Variâncias dos 8 primeiros componentes principais

Para interpretar de forma completa o conjunto de dados, serão analisadas as relações entre as observações (amostras) e entre as variáveis pelos gráficos de score (Figura 45) e loading, respectivamente.

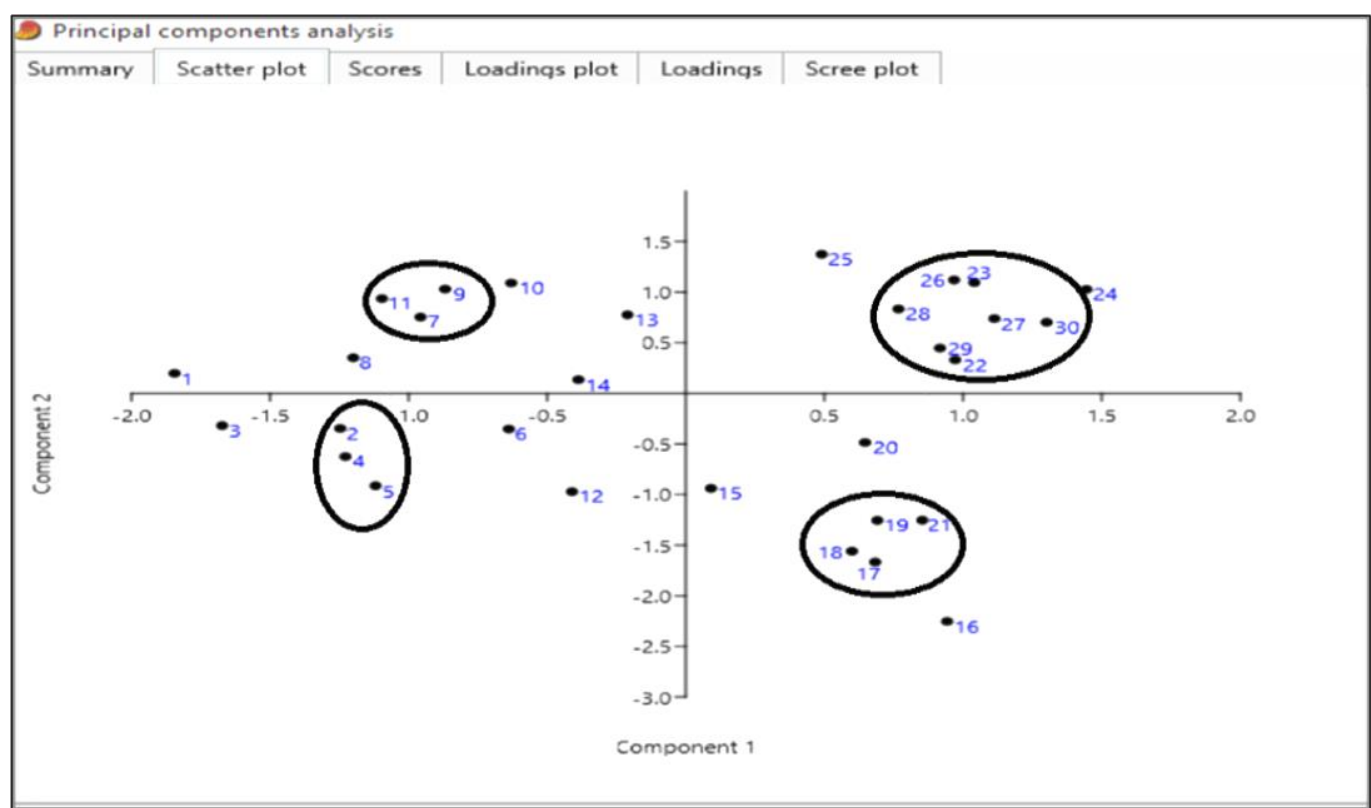

Figura 45-Gráfico de Score 
É possível observar que os conjuntos das seguintes amostras: 2,4,5;7,9,11; $17,18,19,21 ; 2,4$ e5. correspondem aos dias em que o forno teve um desempenho similar na sua operação e as amostras isoladas: 1,3,6,8,10,12,13 e 14 com desempenho diferenciados.

A Figura 46 representa o gráfico em barra do loading, ou seja, a correlação entre o PC1 e os dados originais. Vale observar que as maiores correlações são com o Teor de $\mathrm{SO}_{3}=0,91367(\mathrm{E} 1)$, Consumo de combustível sólido (E2)= 0,83148, Teor de $\mathrm{CO}=0,73397$ (E6), Teor de $\mathrm{Fe}_{2} \mathrm{O}_{3}=-0,71413(\mathrm{~S})$, Teores de alita $\mathrm{M} 1=0,82204$ e M3 $=-0,79847(\mathrm{~S})$ e Teores de $\mathrm{C}_{3} \mathrm{~A}$ cúbica=0,77393 e ortorrômbica $=-0,76755$ (S). Portanto, pode-se interpretar da seguinte forma a operação do forno: O excesso de $\mathrm{SO}_{3}$ tem um impacto na formação de colagem dura na região próxima a entrada do forno e isso é crítico, porque há um risco de causar obstrução de alimentação da farinha e a única providência a ser tomada é a parada de forno. O operador de forno deve ficar atento e solicitar análise de $\mathrm{SO}_{3}$ com uma certa frequência para acompanhar os resultados. Desta forma, o operador toma providências de forma antecipada por meio da redução da alimentação de farinha e combustível sólido. A área de Controle de Qualidade contribui também por meio da execução do cálculo do balanço $\mathrm{SO}_{3}$ /álcalis para fornecimento de subsídio para controle de dosagem de $\mathrm{SO}_{3}$

A correlação é positiva, então conclui-se que quanto maior o teor de $\mathrm{SO}_{3}$, maior tendência a ineficiência operacional. 


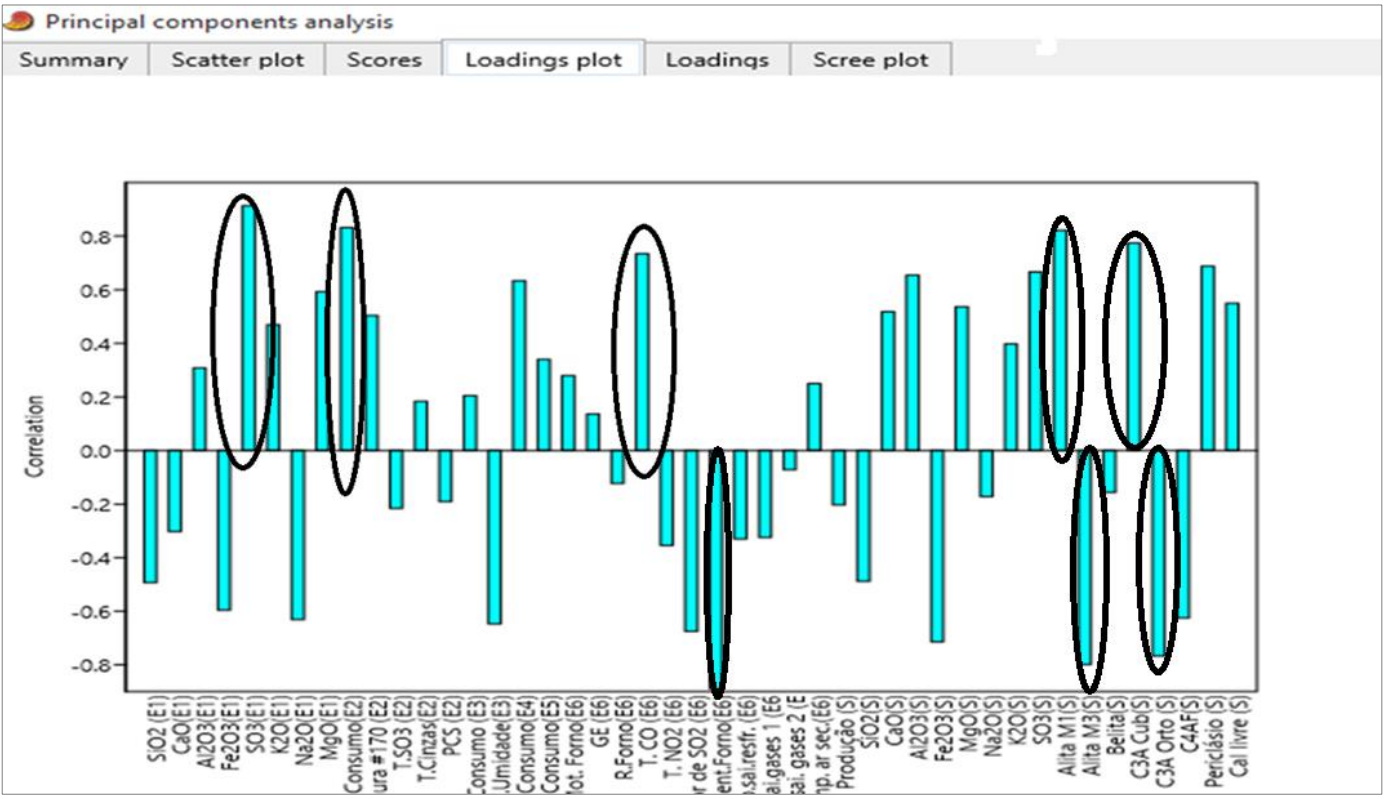

Figura 46-Gráfico em barra de loading do PC1

Quanto ao Consumo de combustível sólido (E2), este é fundamental para controle de combustão de forma adequada para manter a temperatura de clinquerização estável sem gerar ineficiência térmica. A correlação é positiva, então quanto maior o combustível até um certo ponto, maior eficiência operacional. E, finalmente, o teor de CO (E6), é o indicador de ineficiência térmica da reação de combustão no forno. O resultado foi de correlação positiva, então quanto maior o teor de $\mathrm{CO}$, maior ineficiência térmica. O operador de forno deve ficar atento, porque existe também o impacto ambiental na emissão deste gás na chaminé do sistema de despoeiramento do sistema do forno.

Com relação aos dados de saída, tem-se a seguinte situação: a correlação do PC1 com teor de $\mathrm{Fe}_{2} \mathrm{O}_{3}$ (S) resultou num valor negativo. Isso significa uma quantidade muito elevada deste teor pode causar um excesso de fase líquida,e portanto desfavorecendo as reações entre silicatos, reduzindo a formação da alita. Já os teores de alita M1(S) e M3 (S) e $\mathrm{C}_{3} \mathrm{~A}$ cúbica (S) e orthorrômbica (S) têm correlações entre si com sinais contrários. Isso se deve ao fato de que para manter o teor de alita constante, um teor de estrutura deve aumentar e a outra, reduzir.

O PC2 apresenta correlação acima de 0,7 com o Teor de $\mathrm{K}_{2} \mathrm{O}(\mathrm{E} 1)=0,76398$. Já o PC3, tem-se o GE- Grau de enchimento (E6)= -0,70007, Temperatura de saída dos gases $1=0,70584(E 6)$, Temperatura de saída dos gases 2=0,79957 (E6) e Produção= 0,7017 (S). Portanto, pode-se interpretar da seguinte forma: quanto 
maior o $\mathrm{K}_{2} \mathrm{O}$ até um certo limite, maior é a formação da fase líquida* e maior o equilíbrio enxofre álcalis. Vale mencionar que álcalis forma colagens moles nos dutos e ciclones, então é importante também a execução do cálculo do equilíbrio supracitado para controle do álcalis. Já o Grau de enchimento, este tem a seguinte relação com outros parâmetros do forno:

$$
\mathrm{GE}=\frac{3,2 * Q}{D^{3} * n * p}
$$

onde:

GE- Grau de enchimento (\%)

Q- Capacidade produtiva (tpd- toneladas por dia)

D- diâmetro do forno (m)

$\mathrm{p}$ - inclinação do forno (\%)

$\mathrm{n}$ - velocidade do forno (rpm)

*Tem uma participação na formação da fase líquida na mesma proporção que $\mathrm{Na}_{2} \mathrm{O}$ e $\mathrm{MgO}$, mas em menor proporção que $\mathrm{Al}_{2} \mathrm{O}_{3}$ e $\mathrm{Fe}_{2} \mathrm{O}_{3}$.

O grau de enchimento que por definição é o volume de material ocupado pelo forno está relacionado com o seguinte parâmetro operacional do forno: velocidade. Então, se houver uma redução da velocidade mantendo a mesma capacidade produtiva (diâmetro e inclinação do forno são dados construtivos que vão se manter constantes), haverá aumento do grau de enchimento. O material cru não se desloca ao longo do forno tão rápido o que aumenta o volume deste. Se houver a redução do grau de enchimento, o material se desloca com maior velocidade. A correlação negativa significa que quanto maior o grau de enchimento, menor a rotação do forno, portanto menor produção.

O operador de forno deve buscar um equilíbrio entre o grau de enchimento e rotação do forno para que haja um deslocamento do material com o tempo necessário para que seja preparado o suficiente a fim de que sua clinquerização seja realizada de forma adequada. Desta forma, evita-se excesso de consumo de combustível sólido e um eventual descontrole operacional comprometendo custo e qualidade do clínquer.

Já os dados Temperatura de saída dos gases 1 e 2 têm correlação positiva com PC3. Isso significa que se as temperaturas de saída dos gases dos ciclones da Torre Intercambiadora estiverem na faixa normal, ao longo do forno o gradiente de 
temperatura se mantém em condições normais. Portanto, a temperatura de clinquerização está adequada. Considerando que outros parâmetros tais como temperatura do ar secundário e entrada do forno estejam estáveis. Quanto maior estas temperaturas de saída dos gases, maior a tendência em obter boa queimabilidade. O dado Produção (S) também possui correlação positiva com o PC3. Quanto maior a produção de clínquer dentro de sua capacidade, maior a estabilidade operacional do forno.

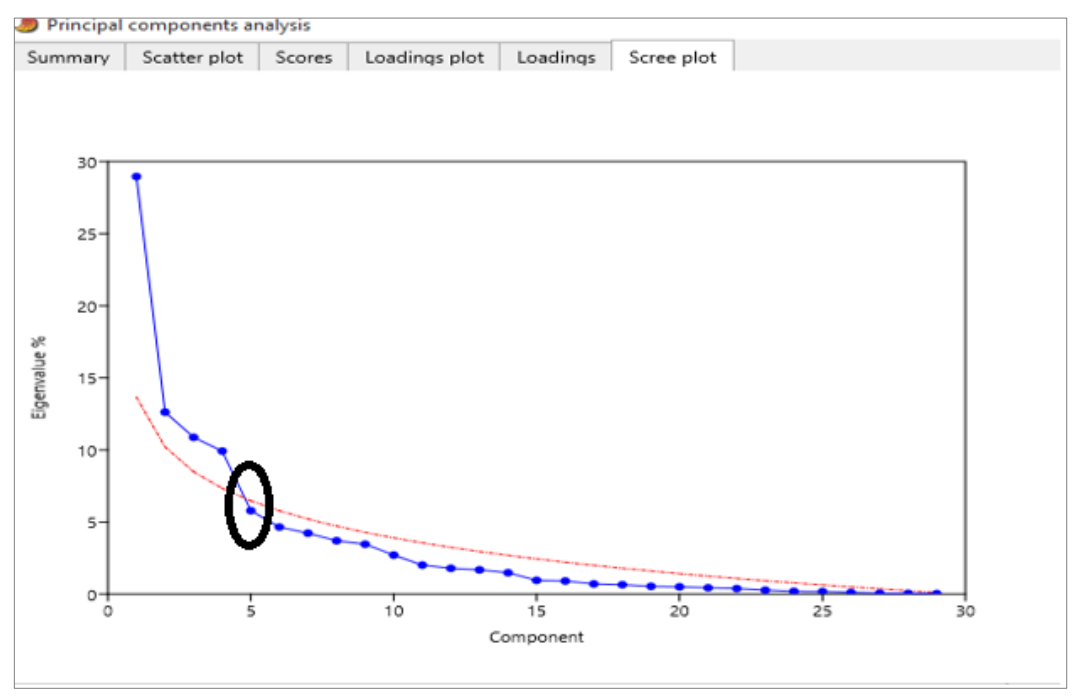

Figura 47-"Screeplot" com círculo de linha preta que indica o ponto de corte

Outro critério para seleção de variáveis mais representativas do conjunto dos componentes principais é pelo "Screeplot" (Vide Figura 47). Este método busca reduzir o grau de subjetividade que o critério de percentual acumulado possui. O procedimento é o seguinte: deve-se observar no gráfico a mudança de inclinação de forma abrupta (definindo um "cotovelo" no gráfico). Neste caso, a mudança é no PC5, justamente onde o autovalor reduz de 10 para próximo de 5\%. É possível observar que após o PC5 as linhas não têm inclinação significativa e tende a formar uma linha reta que não chega ser horizontal. Entre os PC15 e PC20, a linha está praticamente reta e horizontal. Portanto, a maior parte da variância é até o ponto de corte localizado no PC5. A partir do PC5, existe uma menor variância que corresponde a uma baixa inclinação. Por meio deste critério, as variáveis mais representativas vão do PC1 ao PC4. 


\subsection{Ensaios de desempenho físico-mecânico}

O cimento utilizado (CPI-S: $80 \%$ clínquer, $10 \%$ calcário e $10 \%$ de gesso) tem área de superfície específica de $5890 \mathrm{~cm}^{2} / \mathrm{g}$ com finura de $0,43 \%$ na peneira 325 .

\subsubsection{Tempo de Pega}

Os resultados de tempo de início e final de pega estão apresentados na Tabela 19.

Tabela 19 - Valores de tempo de pega

Valores da norma

Tempo de Pega

Valores (min.)

16697

(min.)

\begin{tabular}{ccc}
\hline Início & 113 & $\geq 60$ \\
\hline Final & 170 & - \\
\hline
\end{tabular}

O cimento produzido no teste industrial teve os resultados de tempo de início de pega com atendimento pleno a ABNT NBR 16697 que indica que o tempo mínimo inicial deve ser de 60 minutos. É importante ressaltar que um cimento composto com escória ou pozolana, os tempos de início e final de pega seriam maiores, devido a lentidão do desenvolvimento das reações de hidratação.

\subsubsection{Resistência a compressão}

Os resultados de resistência a compressão com suas respectivas idades estão apresentados na Tabela 20. 
Tabela 20 - Valores de resistência a compressão

\begin{tabular}{ccc}
\hline $\begin{array}{c}\text { Resistência a } \\
\text { compressão (dias) }\end{array}$ & Valores (MPa) & $\begin{array}{c}\text { Valores da norma } \\
16697(\mathrm{MPa})\end{array}$ \\
\hline 1 & 24,3 & - \\
\hline 3 & 36,8 & $\geq 10,0$ \\
\hline 7 & 42,8 & $\geq 20,0$ \\
\hline 28 & 50,8 & $\geq 32,0$
\end{tabular}

Há um atendimento com folga a norma ABNT NBR 16697, ou seja, está bem acima do limite mínimo considerando a classe de resistência 32 (corresponde a resistência mínima aos 28 dias). A resistência a 1 dia para cimentos compostos ou não, exceto $\mathrm{CPV}$, não há uma obrigatoriedade de atender a um limite mínimo. As fábricas fazem o ensaio de resistência a 1 dia por questões mercadológicas. 


\section{5 Conclusões}

Não houve observação de nenhuma variação significativa da mineralogia do clínquer nem na performance do cimento durante o coprocessamento de CSS50. Nos resultados de Difração de Raios-X, detectou-se a forma monoclínica da alita que é típica de clínqueres industriais e devido a incorporação de íons substituintes, se apresenta em temperatura ambiente. A polimorfia do $C_{3} S$ é influenciada pela composição do clínquer, incorporação de elementos menores e taxa de resfriamento. Quanto ao $\mathrm{C}_{3} \mathrm{~A}$, a estrutura predominante é cúbica também típica de clínqueres industriais. Além do fato dos valores dos quatro principais constituintes do clínquer estarem próximos dos compostos de Bogue.

A morfologia dos cristais dos silicatos de cálcio $\left(\mathrm{C}_{3} \mathrm{~S}\right.$ e $\left.\mathrm{C}_{2} \mathrm{~S}\right)$ revelados no Microscópico Ótico de Clínquer demonstram uma relativa normalidade quanto à forma e tamanho desses cristais. Portanto, as condições operacionais de queima e primeiro resfriamento foram normais como discutido na seção anterior. O grau de cristalização da fase intersticial $\left(\mathrm{C}_{3} \mathrm{~A}\right.$ e $\left.\mathrm{C}_{4} \mathrm{AF}\right)$ indicou também um segundo resfriamento normal. A única anormalidade foi a formação de zonas ou aglomerados de belita que indicam leve deficiência de moagem dos grãos de $\mathrm{SiO}_{2}$. Isto não chega a comprometer a alta reatividade do clínquer.

Quanto a análise de componentes principais, de acordo com o primeiro critério de seleção das variáveis mais representativas, ou seja, a distribuição percentual com mais de $80 \%$ estão entre PC1 e PC8. Dentre essas variáveis, destacam-se as correlações que estão acima de 0,7: PC1-Teores de $\mathrm{SO}_{3}$ (E1), de combustível sólido (E2), $\mathrm{CO}$ (E6), $\mathrm{Fe}_{2} \mathrm{O}_{3}(\mathrm{~S})$, (alita M1-S), (alita M3-S), $\left(\mathrm{C}_{3} \mathrm{~A}\right.$ cúbica-S) e $\left(\mathrm{C}_{3} \mathrm{~A}\right.$ orthorrômbica-S); PC2 - Teor de $\mathrm{K}_{2} \mathrm{O}$ (E1); PC3-GE-Grau de enchimento (E6); Temperatura de saída dos gases 1 (E6) e 2(E6) e Produção (S).

No segundo critério pelo "Scree plot", as variáveis mais representativas estão entre PC1 e PC4, justamente onde tem inclinação significativa com altos autovalores. O restante das variáveis tem baixa inclinação e portanto baixos 
autovalores. Este último critério corrobora com o anterior que é arbitrário com restrição de variáveis que apresentem correlação de no mínimo 0,7.

Em relação aos ensaios de cimento, os resultados do cimento produzido no teste industrial atenderam aos limites mínimos exigidos pelas normas ABNT NBR 16607 e NBR 7215 o que indica um cimento com enrijecimento adequado e bom desenvolvimento de resistência a compressão. O tempo de início de pega resultou em 113 minutos (mínimo $60 \mathrm{~min}$.) e as resistências: 36,8 MPa (mínimo 10 MPa);42,8 MPa (mínimo $20 \mathrm{MPa}$ ) e 50,8 MPa (mínimo $32 \mathrm{MPa}$ ). 


\section{6 Recomendações para Trabalhos Futuros}

No intuito de otimizar o trabalho de cunho estatístico, após a tratativa pelo método de PCA, sugere-se fazer um trabalho com redes neurais. A rede neural artificial é um instrumento de processamento de dados inspirado no funcionamento dos neurônios biológicos. Portanto, tem capacidade de receber uma entrada de dados e relacioná-los com a correspondente saída. Isso é possível se a estrutura de rede estiver bem treinada.

Sabendo-se de antemão as variáveis mais representativas do sistema forno de clínquer, pode-se elaborar uma estrutura de rede capaz de relacionar os componentes de entrada e saída referentes a reatividade do clínquer.

Outro fato a ser mencionado é que não houve disponibilidade de maior espaço amostral tais como 3, 6 meses de tempo de operação do forno. Se houvesse mais dados, seria possível obter mais respostas com relação a outras variáveis com correlações altas (acima de 0,7) e/ou recorrência das correlações das variáveis comentadas neste trabalho. 


\section{7 Referências bibliográficas}

AMORIM, L., Construção civil vive crise sem precedentes no Brasil, Revista Exame, 16 jul 2015.

ASSOCIAÇÃO BRASILEIRA DE CIMENTO PORTLAND (ABCP). Uma breve história do Cimento Portland, São Paulo: ABCP, 2009. Disponível em: http://www.abcp.org.br/cms/basico-sobre-cimento/historia/uma-brevehistoria-do-cimento-portland/Acesso em 22 nov. 2017.

ASSOCIAÇÃO BRASILEIRA DE CIMENTO PORTLAND (ABCP). Curso de Microscopia de Clínquer Portland. São Paulo, 2004.

ASSOCIAÇÃO BRASILEIRA DE NORMAS TÉCNICAS (ABNT)- NBR 16697: Cimento Portland - Requisitos. São Paulo, 2018.12p.

ASSOCIAÇÃO BRASILEIRA DE NORMAS TÉCNICAS (ABNT)- NBR 7215: Determinação de resistência à compressão . Rio de Janeiro, 1996.8p.

ASSOCIAÇÃO BRASILEIRA DE NORMAS TÉCNICAS (ABNT)- NBR 16607: Determinação dos tempos de pega.São Paulo, 2018.4p.

BHATTY, J. I. Role of Minor Elements in Cement Manufacture and Use. Portland Cement Association, 1995. 48 p.

CAMPBELL, D.H. Microscopical Examination and Interpretation of Portland Cement and Clinker.zaed. Portland Cement Association, 1999. 214 f. 
CENTURIONE,S.L. A mineralização do Clínquer Portland e seus benefícios tecnológicos.1999. 146 f. Dissertação (Doutorado) - Programa de PósGraduação em Mineralogia e Petrologia. São Paulo.

CENTURIONE,S.L; KIHARA, Y. A mineralização do Clínquer de Cimento Portland com fluorita e sulfato de cálcio e seus benefícios tecnológicos. ANAIS do $44^{\circ}$ Congresso Brasileiro de Cerâmica. São Pedro, SP, 2000.46701-46712.

CNI-Confederação Nacional da Indústria. indústria brasileira de cimento. Base para a Construção do Desenvolvimento. Encontro da Indústria para Sustentabilidade. p.17. Brasília, 2012.

CONAMA- Conselho Nacional de Meio Ambiente. Resolução n²64/26/08/1999

CULLITY, B.D; STOCK, S.R. Elements of X-Ray Diffraction.3aed. New York. Prentice Hall, $2001.569 \mathrm{f}$.

DE LA TORRE, M.A.G.Estudio de cementos y materiales relacionados por el método de Rietveld. 2003. 363 p. Tese (Doutorado)- Universidad de Málaga, Facultad de Ciencias, Departamento de Química Inorgânica, Cristalografia y Mineralogia, Malaga.

DUDA, W.H. Cement Data Book. Berlin: Bauverlag, 1985.

EPE- Empresa de Pesquisa Energética. Relatório Final do Balanço Energético Nacional.2017. Ano base: 2016. 296 f. Ministério de Minas e Energia. Disponível: www.epe.gov.br. Acesso em dez 2017.

GARCIA,I.R. Caracterização dos Principais Materiais envolvidos em uma Produção Industrial de Cimento Portland utilizando Coprocessamento de resíduo.2002.132 f. Dissertação (Doutorado)-Programa de Pós-Graduação 
em Ciência dos Materiais e Metalurgia da Pontifícia Universidade Católica do Rio de Janeiro (PUC-RJ).

GARCÍA-DIAZ, I.; PALOMO,J.G.; PUERTAS, F. Belite cements obtained from ceramic wastes and the mineral pair $\mathrm{CaF}_{2} / \mathrm{CaSO}_{4}$. Cement \& Concrete Composites, 1063-1070, 2011.

GLOBAL CEMENT. http://www.globalcement.com. Acesso em 02/07/19.

GOBBO, L.A. Os compostos do clínquer Portland: sua característica por difração de raios $X$ e quantificação por refinamento de Rietveld. 2003. 157 f. Dissertação (Mestrado)- Instituto de Geociências da Universidade de São Paulo (USP), São Paulo.

GUEIROS, I. Curso de tecnologia do cimento. $2^{\circ}$ Programa Eng Químico Trainee. 2000. Cap. 1, 11, 12.Material interno do GIJS (Grupo Industrial João Santos).

HAMMER, Ø., Harper, D.A.T., Ryan, P.D. 2001. PAST: Paleontological statistics software package for education and data analysis. Palaeontologia Electronica 4(1) 9 pp. http://palaeo-electronica.org/2001 1/past/issue1 01 htm

JOLLIFE, I.T. Principal Component Analisys. $2^{\underline{a}}$ ed. Springer - Verlag New York, Inc, 2002. $478 \mathrm{f}$.

KIHARA, Y. O periclásio no clínquer portland e sua correlação com as expansões do cimento. ASSOCIAÇÃO BRASILEIRA DE CIMENTO PORTLAND (ABCP) e Instituto de Geociências da USP. Jaguaré, SP.1990.

KIHARA, Y; BATTAGIN, A; EVERALDO. Curso de Microscopia Ótica. Publicação interna da Associação Brasileira de Cimento Portland (ABCP), São Paulo, SP,1976. 
KURDOWSKI, W. Cement and Concrete Chemistry. New York. Springer Dordrecht Heidelberg, $2014.705 \mathrm{f}$.

LEA, F.M. The Chemistry of Cement and Concrete, $4^{\circ}$ ed. London: P.C. Hewlet Arnold Pub Ltda., 1998. 1057 p.

MAKI, I.; FUKUDA, K.; YOSHIDA, H.; KUMAKI, J. Effect of $\mathrm{MgO}$ and $\mathrm{SO}_{3}$ on the impurity concentration in alite in Portland cement clinker. Journal of American Ceramic Society, v.75, n.11, 1992, p.3163-3165.

MARINGOLO, V. Clínquer coprocessado: produto de tecnologia integrada para sustentabilidade e competitividade da industria de cimento.2001. 1v. Tese (doutorado)- Instituto de Geociências da Universidade de São Paulo, São Paulo.

MINERAL COMMODITIES SUMMARY. http://usgs.gov/centers/nmic.

PECCHIO, M. A Influência de Fósforo, Enxofre e Estrôncio na Mineralogia do Clínquer Portland. 2013.100f. Dissertação (Mestrado) - Instituto de Geociências da Universidade de São Paulo, São Paulo.

PERAY, E.K. The Rotary Cement Kiln. Chemical Publishing Co., Inc. New York, $1986.386 \mathrm{p}$.

RICHARDSON, Mark. Principal Components Analysis. Maio, 2009. http://www.dsc.ufcg.edu.br/ hmg/disciplinas/posgraduacao/m-copin2014.3/material/SignalProcPCA.pdf

ROSA, Garcia Adálvaro. Análise da Expansão Térmica de Óxidos Cerâmicos utilizando as abordagens de Análise de Componentes Principais e Redes Neurais,2013. Tese (mestrado)- Pontifícia Universidade Católica do Rio de Janeiro, RJ. 
SANTI e FILHO. Combustíveis e riscos ambientais na fabricação de cimento; casos na Região do Calcário ao Norte de Belo Horizonte e possíveis generalizações. II Encontro Nacional de Pós-Graduação e Pesquisa em Ambiente e Sociedade - ANPPAS. Campinas 26 a 29 de maio de 2004.

SCHOLZ, Matthias. Principal Components Analysis. http://www.matthiasscholz.de/.

SHUKUZAWA, K.J. Influência das condições de resfriamento na microestrutura do clínquer e nas propriedades do cimento Portland. Associação Brasileira de Cimento Portland (ABCP).XXX Congresso Brasileiro de Cerâmica, Rio de Janeiro, 1986.

SNIC-Sindicato Nacional da Indústria de Cimento. Disponível em www.snic.org.br/...Acesso em 7 e 8 dez 2017 e 04 fev 2018.

TAYLOR, H.F.W. Cement Chemistry, $2^{a}$ ed. London:Academic Press $1997,475 \mathrm{p}$.

WAGNER, T.C .Efeitos do coprocessamento de resíduos contendo cromo sobre a reação de clinquerização.2004. 110 f. Dissertação (Mestrado) Programa de Pós-Graduação em Ciência dos Materiais e Metalurgia da Pontifícia Universidade Católica do Rio de Janeiro (PUC-Rio).

WILLS, A.B; FINCH, A.J.Mineral Processing Technology: An introduction to the Practical Aspects of ore treatment and Mineral Recovery.8 ed. London. Elsevier, 2016. $497 \mathrm{f}$. 